ASSESSMENT OF SINGLE-SHELL

TANK RESIOUAL LIQUID ISSUES

AT HANFORD SITE, WASHINGTON
K. S. Murthy
L. A. Stout
B. A. Napier
A. E. Reisenauer
D. K. Lands trom

June 1983

Prepared for the

U.S. Department of Energy

under Contract DE-ACO6-76RLO 1830

Pacific Northwest Laboratory

Richland, Washington 99352 


\section{Assessment of Single-Shell Tank Residual Liquid Issues at Hanford Site, Washington}
K. S. Murthy
L. A. Stout
B. A. Napier
A. E. Reisenauer
D. K. Landstrom

June 1983

Prepared for the U.S. Department of Energy under Contract DE-AC06-76RLO 1830

Pacific Northwest Laboratory

Operated for the U.S. Department of Energy by Battelle Memorial Institute 


\title{
DISCLAIMER
}

This report was prepared as an account of work sponsored by an agency of the United States Government. Neither the United States Government nor any agency thereof, nor any of their employees, makes any warranty, express or implied, or assumes any legal liability or responsibility for the accuracy, completeness, or usefulness of any information, apparatus, product, or process disclosed, or represents that its use would not infringe privately owned rights. Reference herein to any specific commercial product, process, or service by trade name, trademark, manufacturer, or otherwise, does not necessarily constitute or imply its endorsement, recommendation, or favoring by the United States Government or any agency thereoi. The views and opinions of authors expressed herein do not necessarily state or reflect those of the United States Government or any agency thereof.

\author{
PACIFIC NORTHWEST LABORATORY \\ operated by \\ BATTELLE \\ for the \\ UNITED STATES DEPARTMENT OF ENERGY \\ under Contract DE-AC06-76RLO 1830
}

\begin{tabular}{|c|c|}
\hline \multicolumn{2}{|c|}{ Printed in the Lnited States of America } \\
\hline \multicolumn{2}{|c|}{ Available :rom } \\
\hline \multirow{2}{*}{\multicolumn{2}{|c|}{$\begin{array}{l}\text { National Techaical Intormation Service } \\
\text { United States Department of Commerce }\end{array}$}} \\
\hline & \\
\hline \multirow{2}{*}{\multicolumn{2}{|c|}{$\begin{array}{l}5285 \text { Port Royal Road } \\
\text { Springield, Virginiz } 22167\end{array}$}} \\
\hline & \\
\hline \multicolumn{2}{|c|}{$\begin{array}{l}\text { MTIS Price Codes A07 } \\
\text { Microfiche A01 }\end{array}$} \\
\hline \multicolumn{2}{|c|}{ Printed Copy } \\
\hline Pages & $\begin{array}{l}\text { Price } \\
\text { Codes }\end{array}$ \\
\hline $001-025$ & $\mathrm{~A} 02$ \\
\hline $026-050$ & $\mathrm{~A} 03$ \\
\hline $051-075$ & A04 \\
\hline $076-100$ & A05 \\
\hline $101-125$ & $A 06$ \\
\hline $126 \cdot 150$ & $\mathrm{~A} 07$ \\
\hline 151.175 & $\mathrm{AOA}$ \\
\hline $176-200$ & A09 \\
\hline $297-225$ & $A 0 ? 0$ \\
\hline $226-250$ & $A 011$ \\
\hline $257-275$ & $\mathrm{~A} 012$ \\
\hline $276-300$ & $A 013$ \\
\hline
\end{tabular}




\section{CONTENTS}

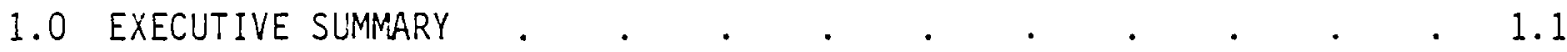

1.1 APPROACH TO ASSESSMENT OF JET PUMPING . . . . . . . 1.2

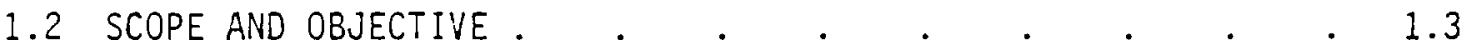

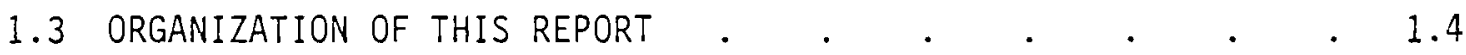

1.4 DESCRIPTION OF JET-PUMPING PROGRAM . . . . . . . . . 1.4

1.5 JET PUMPING AND FINAL DISPOSAL . . . . . . . . . . . 1.6

1.6 DISCUSSION OF RELEASE SCENARIOS AND TRANSPORT MODELING. $\quad 1.7$

1.7 POTENTIAL DOSE IMPACTS OF JET PUMPING . . . . . . . . 1.10

1.8 OVERALL EVALUATION OF JET-PUMPING OPTIONS $\quad . \quad . \quad . \quad . \quad 1.12$

2.0 INTRODUCTION

3.0 DESCRIPTION OF CURRENT AND ALTERNATIVE JET-PUMPING PROGRAMS . 3.1

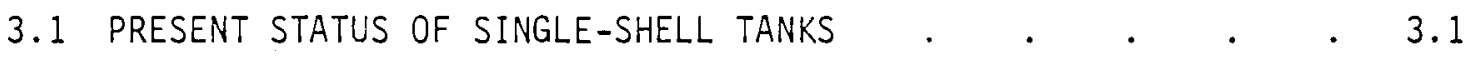

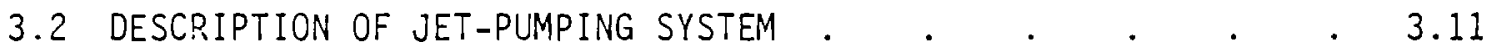

3.3 RELATIONSHIP OF JET PUMPING TO FINAL DISPOSAL $. \quad . \quad$. 3.23

4.0 DISCUSSION OF RELEASE SCENARIOS AND RADIONUCLIDE TRANSPORT • . 4.1

4.1 TANK LEAKS $\quad . \quad$. $\quad$. $\quad . \quad$. . . . . . . . . . 4.1

4.2 OTHER RELEASE SCENARIOS . . . . . . . . . . . . . 4.25

5.0 POTENTIAL IMPACTS OF JET PUMPING .

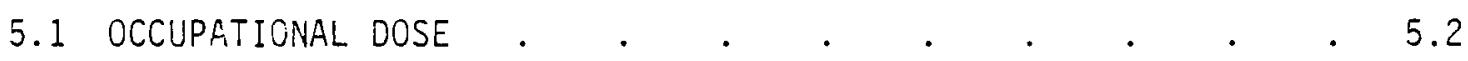

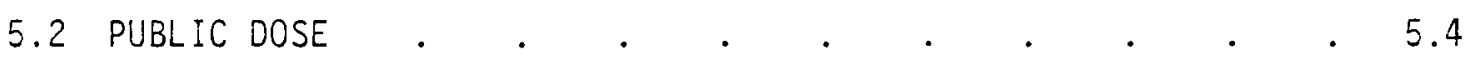

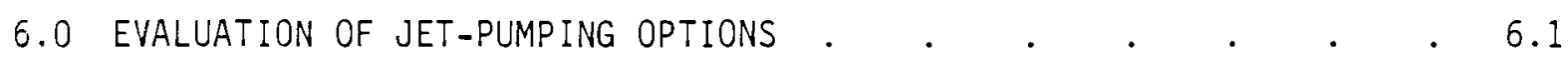

6.1 RADIOLOGICAL CONSEQUENCES OF JET-PUMPING OPERATIONS $\quad$ • 6.1

6.2 POTENTIAL CONSEQUENCES OF UNPLANNED RELEASES . . . . . 6.1

6.3 EFFECT ON FUTURE WASTE DISPOSAL METHODS . . . . . . 6.3

6.4 EFFECT ON EXPENDITURES . . . . . . . . . . . 6.3

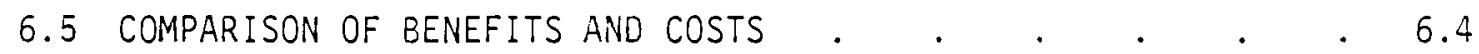

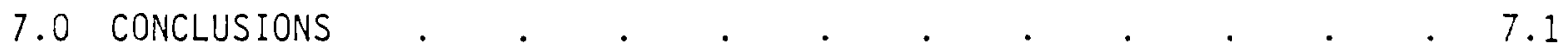

APPENDIX A: BRIEF DESCRIPTION OF HYDROLOGIC MODELS

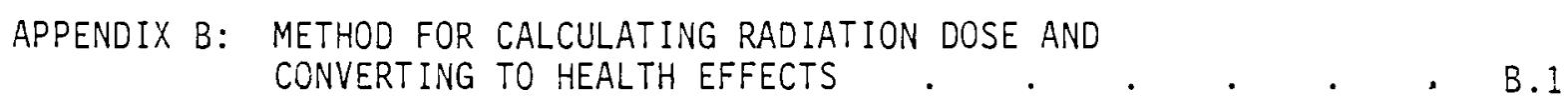

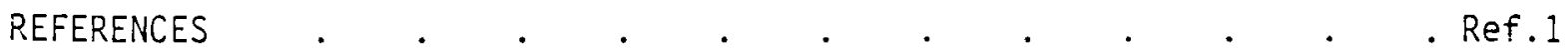




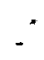




\section{TABLES}

1.1 Parametric Comparison of Jet Pumping the Single-Shell Tanks to Different Residual Liquid Retention Levels as of May 1982

1.2 Summary of Estimated Integrated Radiation Doses for

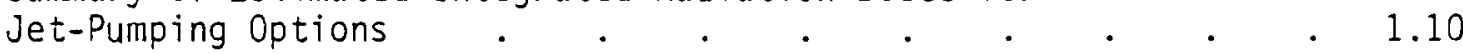

1.3 Summary of Benefits and Costs of Jet-Pumping Options . . . 1.13

3.1 Data on High-Level Wastes Stored in Single-Shell Tanks . . 3.2

3.2 Dimensions of Single-Shell Tanks . . . . . . . . . . . 3.3

3.3 Waste Characteristics for the Design of Single-Shell Tanks . . 3.3

3.4 Representative Composition of Salt-Well Liquor . . . . . 3.5

3.5 Inventory of Single-Shell Tank Contents . . . . . . . . 3.6

3.6 List of Single-Shell Tanks Confirmed as Leaking . . . . . 3.18

3.7 Status of Jet-Pumping Equipment Installation as of May $1982 \quad 3.16$

3.8 Comparison of Residual Drainable Interstitial Liquid Volumes

3.9 Comparison of Current and Alternative Jet-Pumping Termination Levels. $. \quad . \quad . \quad . \quad . \quad . \quad . \quad . \quad . \quad 3.18$

3.10 Estimate of Total Program Costs for Jet-Pumping Options . $\quad 3.21$

4.1 Input Parameters for the Multicomponent Mass Transport Model Flow Tubes for Each of the Modeled Tank Farm Areas . . . 4.12

4.2 Radionuclides of Concern, Their Half-Lives and $\mathrm{Kd}$ Coefficients Chosen . . . . . . . . . . . 4.13

4.3 Residual Volumes by Tank Farm Areas at Various Termination
Levels (in 1,000 gal) . . . . . . . . . . . . . 4.15

\begin{tabular}{l} 
4.4 Inventory of Radionuclides of Concern Remaining in Drainable \\
Liquid \\
\hline
\end{tabular}

4.5 Radionuclides Released to the Atmosphere by a Catastrophic

5.1 Summary of Interstitial Liquids in Hanford Tank Farms Pumped and Residual for Various Pumping Termination Levels . . . 5.3

5.2 Potential Tank Farm Surface Soil Contamination Levels Following

5.3 Potential External Dose Rate from Contamination Levels of Table 5.2 . . . 5.4

5.4 Radiation Doses to the General Public from Routine Atmospheric Releases During Processing of Jet-Pumped Liquids . . . . 5.6 
5.5 Radiation Doses to the General Public Resulting from a Tank Dome Collapse.

5.6 Integrated Population Doses Over 10,000 Years Resulting from Leakage of Interstitial Liquids from Tank Farm Groups at Various Pumping Termination Levels

5.7 Peak Individual Lifetime Doses from Leakage of Interstitial Liquids from Tank Farm Groups at Various Pumping Termination Levels

6. 1 Summary of Benefits and Costs of Jet-Pumping Options (A) doses are potential estimated doses)

6.2 Unit Costs of Each Incremental Level of Interstitial Liquid Removed

A.1 Summary of Radionuclide Transport Modeling to the Columbia River

B.1 Computer Programs Used to Calculate Potential Radiation Doses from Releases of Radionuclides . . . . . . . . B.2

B.2 Health Effects Risk Factors Recormended in DOE/EIS-0046F . . B.7

B.3 Integrated Population Doses Over 10,000 Years Resulting from Leakage of Interstitial Liquids (including ${ }^{237} \mathrm{~Np}$ fraction) at Various Pumping Termination Levels 


\section{FIGURES}

1.1 Cost Comparison of Jet-Pumping Options . . . . . . . . 1.6

3.1 Tank Contents After Jet Pumping . . . . . . . . . . 3.7

3.2 Illustration of Jet Pump and Well Pit . . . . . . . . . 3.13

3.3 Height of Interstitial Liquid Versus Time Required for Jet

3.4 Histogram of Drainable Liquid Volumes Contained in
Single-Shell Tanks. . . . . . . . . . . . . . . . . 3.18

3.5 Effect of Alternative Jet Pumping Termination Levels on Time
Schedules

3.6 Cost Comparison of Jet-Pumping Options . . . . . . . . . 3.22

4.1 200-West Area Wells--Experimental Model Data Fit . . . . 4.7

4.2 200-East Area Wells--Experimental Model Data Fit. . . . 4.8

4.3 Water Table Contours and Flow Tubes from Tank Farm Areas to the Columbia River for 1980 Steady-State Conditions . . 4.11

4.4 Discharge of ${ }^{99} \mathrm{Tc}$ to the Columbia River from A and C Tank Farms. . . . . . . . . . . 4.17

4.5 Discharge of ${ }^{129}$ I to the Columbia River from A and C Tank Farms. . . . . . . . . . 4.17

4.6 Subsurface View of Wells with Readings $>50,000 \mathrm{cpm}$ and Estimated Leak Pattern for Tank 241-BX-102 as of January 1971 . . . 4.20

4.7 Three-Dimensional Drawing of Zone of Contamination with
Respect to the 241-T-106, etc. . . . . . . . . . 4.23

4.8 A Comparison of the Boundaries of the Contaminated Zone

5.1 Integrated Collective Total Body Doses Resulting from Release of a 11 Drainable Interstitial Liquid from the $S$ and SX Farms for the Termination of Pumping Option . $. \quad . \quad . \quad . \quad$. 5.11

5.2 Integrated Collective Thyroid Doses Resulting from Release of all Drainable Interstitial Liquid from the $S$ and SX Farms for the Termination of Pumping Option . . $\quad 5.12$

5.3 Integrated Collective GI-LLI Tract Doses Resulting from Release of all Drainable Interstitial Liquids from the $S$ and $S X$ Farms for the Termination of Pumping Option . . . . . . 5.13

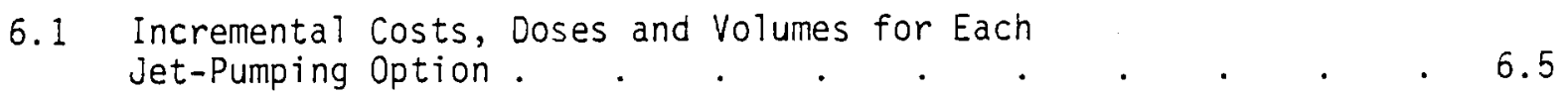

A.1 Nodal Recharge/Withdrawal Phenomena . . . . . . . A.3

A.2 Data Output from Flow Modeling of the B Tank Farm for
the No Pumping Case 99 TC Isotope . . . . . . A.12 
A.3 Data Output from Flow Modeling of the B Tank Farm for the No Pumping Case 129 I Isotope.

A.4 Data Output from Flow Modeling of the B Tank Farm for the No Pumping Case $237 \mathrm{NP}$ Isotope

B.1 Computer Programs for Calculating Public Doses from Routine Airborne Releases of Radionuclides

B.2 Computer Programs for Calculating Public Doses from Accidental Airborne Releases

B.3 Computer Programs for Calculating 10,000-Yr Integrated Population Doses from Releases to Ground water

B.4 Integrated Collective Total Body Dose from Leakage from the $S$ and SX Farms, Termination of Pumping Option Integrated Collective Bone Dose from Leakage from the $S$ and SX Farms, Termination of Pumping Option . . .

B.6 Integrated Collective Lung Dose from Leakage from the $S$ and SX Farms, Termination of Pumping Option . . . . . . B.12

B.7 Integrated Collective Thyroid Dose from Leakage from the $S$ and SX Farms, Termination of Pumping Option . . . . . . B.12

B.8 Integrated Collective GI Tract Dose from Leakage from the $S$ and SX Farms, Termination of Pumping Option

S and SX Farms, Termination of Pumping Option 


\subsection{EXECUTIVE SUMMARY}

This report provides an assessment of the overall effectiveness and implications of jet pumping the interstitial liquids (IL) from single-shell tanks at Hanford. The jet-pumping program, currently in progress at Hanford, involves the planned removal of IL contained in 89 of the 149 single-shell tanks and its transfer to double-shell tanks after volume reduction by evaporation. The purpose of this report is to estimate the public and worker doses associated with 1) terminating pumping immediately, 2) pumping to a 100,000-gal limit per tank, 3) pumping to a 50,000-gal limit per tank, and 4) pumping to the maximum practical liquid removal level of 30,000 gal. (a) Assessment of the costeffectiveness of these various levels of pumping in minimizing any undue health and safety risks to the public or worker is also presented.

An important element of the DOE's waste management operations at Hanford is the management of wastes contained in 149 deactivated single-shell tanks. (b) As of May 1982 these 149 tanks contained a total of approximately 11 million gal of liquids (one million gal of supernatant liquids and the balance IL), and about 38 million gal of solids (i.e., salt cake and sludge). Of the $10 \mathrm{mil}$ lion gal of $\mathrm{IL}$, about eight million gal are estimated to be pumpable ${ }^{(c)}$ with specially constructed pumps (known as jet pumps). Details of the jet pump are given in Chapter 3.0 (page 3.12). The jet pump can also pump the one million gal of supernatant liquids.

Specifically, 89 of the 149 tanks are estimated to contain most of the pumpable liquids. These 89 tanks are currently scheduled to receive jet pumping to remove the residual liquids based on tank selection criteria developed by Rockwell (Kurath 1981). The purpose of i iquid removal is to stabilize the waste in the tanks. This stabilization is expected to be conducive to the adoption of final disposal steps that are being investigated and developed.

\footnotetext{
(a) The maximum practical limit of pumping is currently defined as the continuation of pumping until the pumping rate approaches $0.05 \mathrm{gpm}$.

(b) There are 20 active double-shell tanks, each with a 1,000,000-gal capacity. This study does not include an assessment of double-shell tanks.

(c) This is in addition to the 1.6 million gal already pumped as of May $31,1982$.
} 
Prior to the adoption of full-scale jet pumping in December 1981, it was tested for about three years (during 1977 to 1980) as a means of removing the difficult-to-pump IL contained within the salt-cake matrix. The salt-cake matrix resulted after the evaporation of about 134 million gal of liquids removed from the single-shell tanks by the waste volume reduction and solidification program that began about 1960 and concluded about 1980. The jet-pumping program is intended to stabilize the wastes as a sequel to the waste solidification program and represents a continuation of the efforts to remove most of the drainable liquids from single-shell tanks.

The jet-pumping program as presently conceived (Bowers et al. 1982) would remove an additiona? eight million gal (approximately) of liquids from the single-shell tanks, i.e., about five percent of the 134 million gal already removed. If this was done, there would be no liquids in single-shell tanks that could efficiently be pumped out. As a result, the DOE would probably be perceived as having taken all immediate reasonable steps to avoid or minimize contact of waste liquids with the soil if a tank leaks. This appeared consistent with Richland Operations office (DOE-RL) requirements contained in the then applicable Manual Chapter 0511 (USERCA 1973):

"All nondischargeable radioactive liquid waste shall be solidified to the extent technically and economically practicable. .

The use of existing 200-Arrea single-shell underground tanks for storage of nondischargeable liquid wastes shall be eliminated as soon as technically and economically practicable."

\subsection{APPROACH TO ASSESSMENT OF JET PUMPING}

In this report, the assessment of jet pumping focuses primarily on the health and safety of the workers and the public with a brief discussion of economic practicability based on cost information provided by Rockwell. Technical facts are presented as they are currently defined. Conclusions are based primarily on the technical assessment including public health and safety aspects. Whether DOE should adopt the obvious conclusions of the technical arguments or should weigh those conclusions relative to the sociopolitical aspects is not discussed. 


\subsection{SCOPE AND OBJECTIVE}

The following elements constitute the scope of this report:

- potential dose to the public and workers from exposures resulting from total jet-pumping operations to retain maximum volumes of 100,000 , 50,000 , or $30,000^{(\mathrm{a})}$ gal of IL in each tank

- potential doses from postulated tank leaks (total available liquids) in each area after jet pumping to termination levels of: a) 100,000 gal, b) 50,000 gal, c) $30,000 \mathrm{gal}$, and d) leakage of the total available liquids from each area if the jet pumping program were terminated immediately; these constitute four options within the jet-pumping program

- comparison of doses and dollar costs of immediate termination of pumping, and of removing the pumpable liquids down to a final volume of 100,000, 50,000 , or 30,000 gal in each tank

- a qualitative discussion of the relationship between jet pumping and possible in-situ disposal of the single-shell tank wastes that would remain after jet pumping

- environmental aspects of nonradioactive chemicals present in the tank liquids.

The objective of this study is to assist DOE in assessing the issues related to residual liquid removal from Hanford's single-shell tanks. This assessment is expected to provide a focus on the overall program and ul timate goals of jet pumping.

It is necessary to note some underlying technical reasons that form part of the planning process (now underway toward the final disposal of the singleshel1 tank wastes) which appears to prefer the in-situ disposal of these wastes. The various disposal processes are briefly discussed in Section 3.3 of Chapter 3.0. Among technical reasons that could support the disposal of the wastes in situ are:

(a) The volume of $30,000 \mathrm{gal}$ is used throughout this document to designate the maximum pumping case (present program). This program could more accurately be described as pumping to the practical limit and generally would result in a heel of less than 30,000 gal. 
- the advantageous characteristics of the Hanford Site soils in which these tanks are located and of the site hydrology, both of which have demonstrated the lack of significant radiation hazard to public health and safety from past leaks

- the lack of sufficient water needed to leach the tank contents to the ground-water table

- the dedicated nature of the Hanford Site that precludes its use for civilian purposes and the remoteness of the 200 Areas (in which the tanks are located) from population centers.

\subsection{ORGANIZATION OF THIS REPORT}

In this report there are four major descriptive chapters. Chapter 3.0 describes the jet-pumping program, the options, and related details. Chapter 4.0 presents a discussion of the scenarios for potential release of the tank contents to the soil, the transport modeling to estimate movement of radionuclides to ground water, and releases to ambient air environments. Chapter 5.0 describes the potential consequences of the release and the occupational and public doses from jet pumping. Chapter 6.0 presents an overall evaluation, and Chapter 7.0 presents the conclusions of the report.

\subsection{DESCRIPTION OF JET-PUMPING PROGRAM}

Jet pumping is a relatively simple physical process that uses a modified centrifugal pump to permit very low pumping rates. These rates ( 2 to $0.05 \mathrm{gpm}$ ) result from the low rate of movement of liquor held in the interstices of the salt cake to the salt well. A final removal rate of $0.05 \mathrm{gpm}$ was chosen for the current jet-pumping program. When this rate is reached, about 80 percent of the pumpable liquids would be removed.

As of May 1982, a total of about 1.6 million gal of IL had been pumped from the tank farms $S(800,000 \mathrm{gal})$, TX $(800,000 \mathrm{gal})$ and BY (50,000 gal). Also, 47 salt-well screens, 11 liquid observation wells, and 24 jet pumps had been instâlled (Table 3.7, page 3.16). 


\subsubsection{Options to Current Program}

The termination level for the current program (maximum pumping) is equivalent to the retention of approximately $30,000 \mathrm{gal}$ of IL in most of the 89 tanks now selected for jet pumping. Other termination levels examined in this report are the 100,000 and $50,000 \mathrm{gal}$ of IL retained in the tanks, in addition to terminating pumping immediately (FY-1983). Table 1.1 compares the IL volumes and other parameters at these four termination levels. The table shows that 65 percent of the IL is left as residual liquor at the 100,000-gal termination level 40 percent of the IL is left as residual liquor at the 50,000-gal termination level as compared to 20 percent at the 30,000-gal termination level. The estimated costs for each option are compared in Figure 1.1.

TABLE 1.1. Parametric Comparison of Jet Pumping the Single-Shell Tanks to Different Residual Liquid Retention Levels as of May 1982

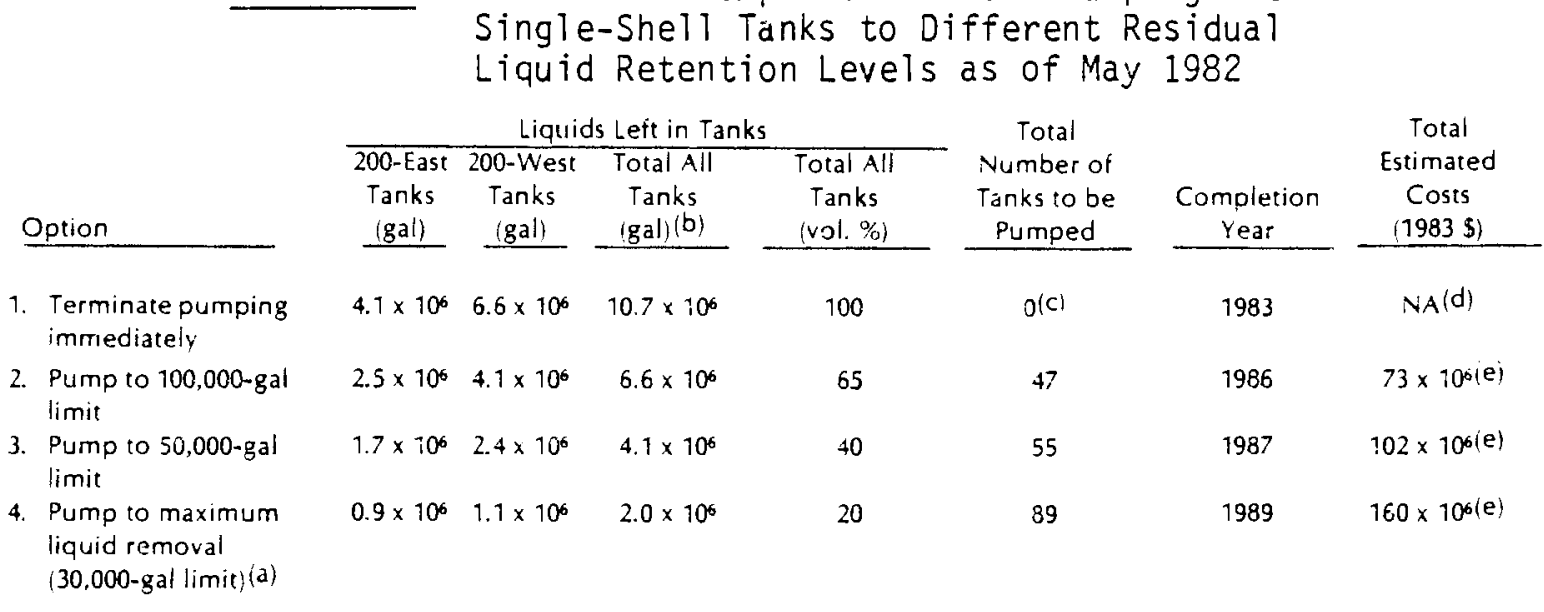

(a) This option may be termed the "maximum pumping" case.

(b) These volumes are based on estimated data as of May 31, 1982. More recent figures show that these volumes have been overestimated by about 0.9 million gallons. The conclusions of this report would not be affected by the decrease in the estimated voiumes.

(c) About 25 tanks would be pumped before termination in mid-FY 1983. Total volume pumped as of May 1982 was about $1.6 \times 10^{6} \mathrm{gal}$, from BY, $S$ and TX farms.

(d) $N A=$ not applicable since no costs would be involved in pumping. However, about $\$ 1$ million are estimated for shutdown and decommissioning as a one-time cost.

(e) All cost data used in this report were provided by Rockwell. They represent approximate gross costs by major categories shown in Figure 1.7. Details of the components of these costs are not available for an independent check. 


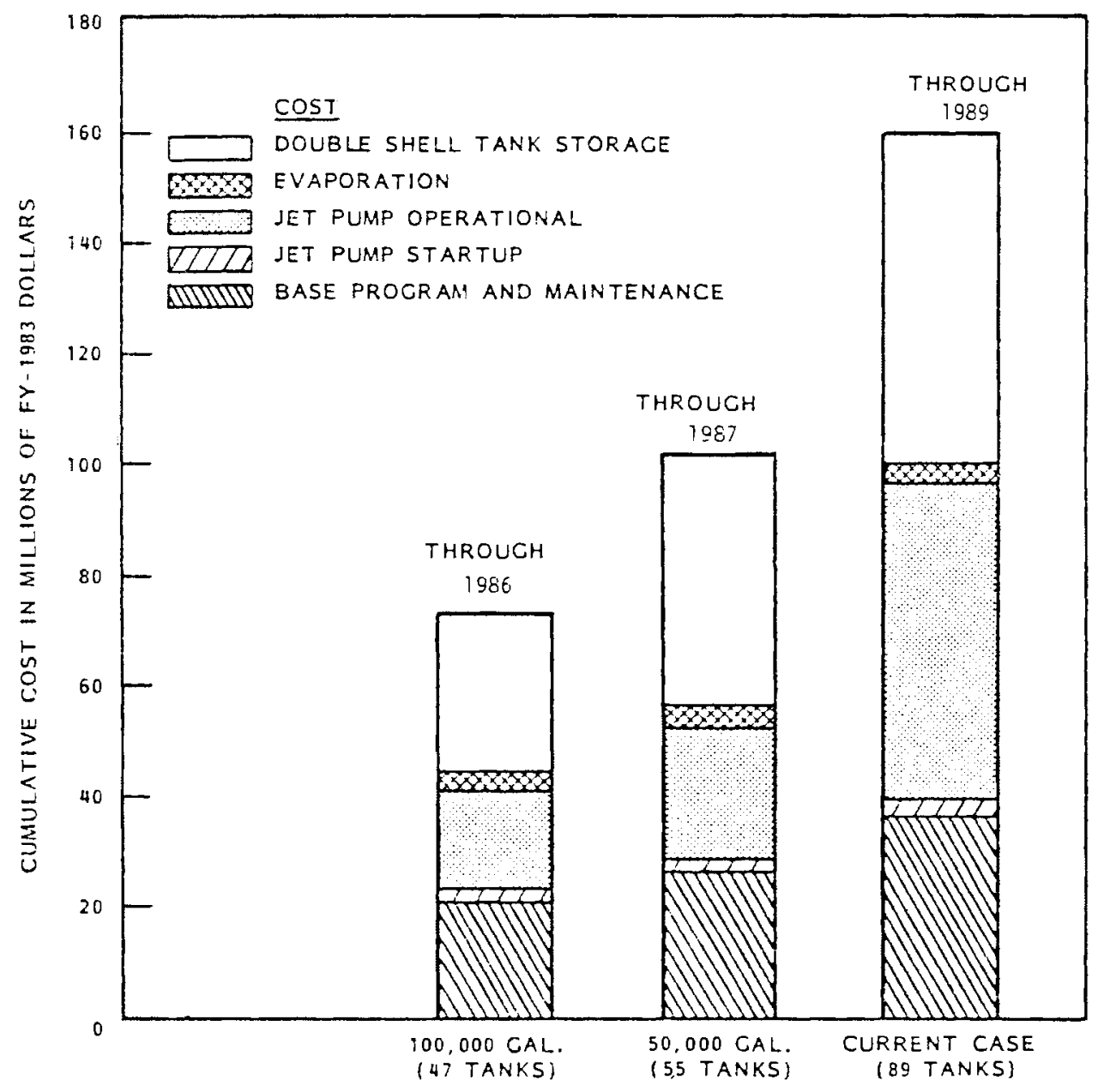

FIGURE 1.1. Cost Comparison of Jet-Pumping Options

\subsection{JET PUMPING AND FINAL DISPOSAL}

Two final disposal methods are being considered for wastes generated on the Hanford Site since it was dedicated in 1943. These wastes known as Hanford defense wastes (HDW) are being considered for either in-situ or geologic disposal. However, the preferred disposal method for HDW has not been defined, and it may well be that different techniques would be selected for different waste tanks, depending on the particular circumstances and tank contents.

A qualitative evaluation of the relationship between in-situ disposal and jet pumping was made. In-situ disposal may be defined as the addition of 
appropriate combinations of natural and engineered intrusion-erosion barriers so that contaminated wastes are isolated in place from the biosphere. With respect to high-level waste (HLW) tanks, this is currently considered to include placement of a confinement barrier to deter intrusion into the storage tanks. The barrier consists of an earth cover 50-ft thick, and a layer of rock rubble to provide an additional barrier and protection from erosion.

Since the concrete tank domes constitute a potential structural failure problem, the planned in-situ disposal method includes filling the dome voids with incompressible materials (sand, dirt, and grout) to support the tank dome and walls during subsequent disposal steps (Rockwell 1982). Since jet pumping is considered to be an interim step toward in-situ disposal of HLW in the single-shell tanks, its value needs examination; the need to jet pump as a necessary step towards implementing in-situ disposal is not established on a technical basis. Removal of IL by jet pumping might reduce the liquid-soil contact after possible tank leakages during the interim period until in-situ disposal can be implemented. Removal of the liquid would also tend to create a firmer solid mass, better able to support the inert material added to the dome void. Therefore, insofar as can be ascertained from available data, jet pumping would not preclude implementation of in-situ disposal.

Specific in-situ and geologic disposal techniques are further described in Sections 3.3 .1 and 3.3 .2 , respectively. Regarding their compatibility with the four jet-pumping options, neither of the disposal techniques would be precluded by adoption of any of the jet-pumping options. However, since techniques for final disposal are still in the experimental/demonstration stage, the optimum level of liquid waste remaining in a tank prior to implementation of in-situ or geologic disposal has not been determined.

\subsection{DISCUSSION OF RELEASE SCENARIOS AND TRANSPORT MODELING}

Twenty-six of the 149 single-shell tanks developed confirmed leaks of various sizes during the period from 1956 to 1981; the remaining tanks are also expected to develop leaks at some point in the future. To adequately predict the dose consequences of future leaks, it is necessary to postulate 
release scenarios (a series of events that lead to a release). One release scenario for a tank leak simply assumes that all of the drainable liquid in the tanks becomes simultaneously available for transport in the soils under the tank farms. This is a very conservative assumption since it is highiy unlikely that all tanks would leak simultaneously. (a) Other assumptions include very conservative values for the soil retardation coefficients ( $K d)$ and no credit is taken for the volume of liquid that would be retained by capillary forces in the soil above the water table. Thus, the consequences are for a "worst-case" analysis. For this or any other release scenario, models must be employed to predict:

- quantities and rates of radionuclides released

- potential pathways to the environment

- transit time

- retardation factors for individual radionuclides

- quantities of radionuclides actually reaching the environment.

The models must be based on existing geology and hydrology (hydrogeology) of the Hanford Site.

The basic hydrogeology of the Hanford Site unconfined aquifer can be described as well understood and documented. In this report, using a combination of theoretical analysis and experimertal tests, the predicted transport of tritium contained ir the water table to the Columibia River (the exposure pathway to mar) has been verified and the modeling results confirmed. The movement of the various radionuclides in the soils under the tank farms has been modeled by using existing data from radionuclide discharge from underground cribs to predict the "breakthrough" time (time for mobile radionuclides to reach the water table). By combining the hydrogeologic model with this soil-transport model, reasonably reliable estimates of radionuclide transport can be made and used as input parameters for dose calculations, or consequence analyses of a tank leaking. Similarly, other postulated scenarios for radionuclide release (i.e., tank collapse or explosion) can also be modeled to provide a conservative estimate of the consequences of the postulated events.

(a) The most probable case is that the tanks will begin leaking over a period of severai decades and each tank will leak about $0.03 \mathrm{gal} / \mathrm{min}$ into the unsaturated zone. 
The physical and technical properties of the sediments underlying the tank farms retard the transport of most leaked radionuclides (noncomplexed) to the water table. The properties that retard the movement of radionuclides in the unsaturated zone beneath the tanks, i.e., adsorption and layering, and the pattern and rates of ground-water movement are confirmed by actual measurement. The body of existing theoretical and experimental work supports the view that, unless large amounts of water are placed on the soil surface above the tanks (considered to be highly unlikely as a natural event), there is little probability that the majority of leaked radionuclides from the tanks will ever reach the water table. (a) The modeling of waste transport is based on the assumption that the unabsorbed (mobile) radionuclides such as technetium99 and iodine-129 will eventually reach the Columbia River.

In examining other potential release scenarios, the potential for a tank dome collapse was reviewed. The source terms were estimated based on removing as much liquid as possible (corresponding to the less than 30,000 gal of remaining IL). The presence of liquids (wet conditions) in the tank (surface layer) would act to reduce the air expulsion emissions of particulate in the event of a dome failure by as much as two orders of magnitude. From available literature, two scenarios were developed and scurce terms obtained for damp (after jet pumping) and wet (existing conditions) salt cakes, respectively.

Other release scenarios of a more "generic" nature such as major floods, meteorite impacts, crashing airplanes or sabotage were also reviewed. None of these scenarios are directly related to the jet-pumping program and the consequences would be essentially independent of any pumping program. Therefore, these scenarios were excluded from further investigation. A major flood would be nature-induced (equivalent to 900 times the average annual flow of the

(a) The movement of nonradioactive components such as cadmium, mercury, lead, and nitrates was analyzed. Of these only the nitrates would reach the ground water; the concentrations are estimated to be less than $40 \mathrm{ppm}$ in well-water samples outside the 200 Area boundaries and produce an insignificant amount in the river. 
Columbia River) and would not significantly affect the elevation of the groundwater table in the 200 Areas, but could exhume the waste by inundation of both the waste storage areas (Wallace et al. 1980). The occurrence of such a nature-induced flood is estimated to be unlikely in 1,000 years and very likely in 10,000 years.

\subsection{POTENTIAL DOSE IMPACTS OF JET PUMPING}

The present program (maximum pumping) for removal of IL from the singleshell tanks will result in no significant radiation hazard to public health and safety as discussed in Chapter 5.0. However, there are some minor sources of atmospheric release that result in radiation doses to the offsite general public, as well as provide a source of occupational exposure. Any reduction in operation of the jet-pumping program would result in reductions of estimated operations-related worker and public radiation exposures. However, reduced pumping would leave greater quantities of liquid in the tanks, with the attendant potential for leakage and possible longterm public exposure to radiation from the leaked material if the waste is not disposed of in the next few decades. The magnitude of doses that may be received from continued operations, and the potential hazard of future releases from leaks of the liquid quantity allowed to remain, are indicated in Table 1.2.

\section{TABLE 1.2. Summary of Estimated Integrated Radiation Doses for Jet-Pumping Options}

\begin{tabular}{|c|c|c|c|c|c|c|c|}
\hline \multirow[b]{4}{*}{ Option } & \multicolumn{3}{|c|}{ Doses from Operations } & \multicolumn{4}{|c|}{ Doses from Postulated Leaks } \\
\hline & \multirow{3}{*}{$\begin{array}{c}\text { Cumulative } \\
\text { Total Body } \\
\text { Doses (worker) } \\
\text { man-rems(a) } \\
\end{array}$} & \multicolumn{2}{|c|}{$\begin{array}{l}\text { Total Body Dose to } \\
\text { Regional Population }\end{array}$} & \multirow{2}{*}{\multicolumn{2}{|c|}{$\begin{array}{l}\text { Total man-rem of an } \\
\text { Assumed Population } \\
\text { of } 200 \times 10^{6} \\
\text { Over } 10,000 \text { Years }\end{array}$}} & \multirow{2}{*}{\multicolumn{2}{|c|}{$\begin{array}{c}\text { As Percent of Natural } \\
\text { Background } \\
\text { Radiation Doses (c) }\end{array}$}} \\
\hline & & man-rem & $\begin{array}{c}\text { As Percent of } \\
\text { Natural }\end{array}$ & & & & \\
\hline & & Total(b) & Background (b) & Whole Body & Thyroid & Whole Body & Thyroid \\
\hline $\begin{array}{l}\text { 1. Terminate pumping } \\
\text { immediately }\end{array}$ & 0 & 0 & 0 & 20 & 3,000 & $1 \times 10^{-6}$ & $1 \times 10^{-4}$ \\
\hline $\begin{array}{l}\text { 2. Pump to } 100,000-\mathrm{gal} \\
\text { limit }\end{array}$ & 200 & $3 \times 10^{-2}=$ & $0.8 \times 10^{-5}$ & 10 & 2,000 & $5 \times 10^{-}$ & $8 \times 10^{-5}$ \\
\hline $\begin{array}{l}\text { 3. Pump to } 50,000-\mathrm{gal} \\
\text { limit }\end{array}$ & 300 & $4 \times 10^{-2}$ & $1 \times 10^{-5}$ & 6 & 900 & $3 \times 10^{-7}$ & $4 \times 70^{-5}$ \\
\hline $\begin{array}{l}\text { 4. Pump to maximum } \\
\text { liquid removal } \\
\text { (30,000-gal limit) }\end{array}$ & 500 & $6 \times 10^{-2}$ & $2 \times 10^{-5}$ & 3 & 400 & $2 \times 10^{-7}$ & $2 \times 10^{-5}$ \\
\hline
\end{tabular}


The highest estimated population dose from jet-pumping operations (primarily operations of evaporators) will be 0.06 man-rem over a 10 -yr operating period. Comparable natural background radiation dose would be 340,000 man-rem over the same period. The estimated maximum individual lifetime dose from operations will be 0.003 mrem to the total body. Comparable lifetime dose from natural background would be about 7,000 mrem.

Doses from potential leaks(a) of residual liquids in all tanks are also shown in Table 1.2. For the case of' immediate termination of pumping, a maximum dose of 2,600 man-rem to the thyroid would be received by the population of 200 million (assumed population integrated over 10,000 yr). This dose would be insignificant when compared with the dose of 2 billion man-rem from natural background radiation received by the same assumed population.

The controlling radionuclides that contribute to these doses are technetium-99 and iodine-129 both of which are available only in small quantities. Other radionuclides of potential concern (cesium-137, strontium-90, neptunium-237) were also analyzed. Hydrological modeling indicated that although cesium-137 and strontium-90 are available in greater quantities, they will never reach the accessible environment before decay due to their relatively short half-lives and soil sorption. The trace amounts of neptunium-237 available have a very long half-life, but are not expected to reach the ground water due primarily to the lack of sufficient driving liquids and soil sorption. In any

(a) Little information (data) is readily available for this analysis to warrant rigorous modeling of radionuclide transport through the vadose (unsaturated soil) zone beneath the tank. Therefore, detailed surrogate information (from radionuclide disposal in cribs near the tanks) was used to fit the crib data on actual radionuclide transport through the vadose zone to derive a simplified physical transport model. This model predicted the arrival time and quantities of radionuclides reaching the ground-water system. The use of surrogate data (the best available option for this study at this time) is both reasonable and conservative. After the radionuclides reach the ground water, their further transport to the Columbia River was modeled using standard Hanford ground-water models such as VTT (Variable Thickness Transient) and MMT (MuTicomponent Mass Transport) codes. The surrogate data are reasonable because they can be verified by physical measurements and conservative because of the assumed amounts and simultaneous release of all liquids. 
event, radiation doses from neptunium-237 to critical organs were estimated, and found to be insignificant (Appendix $B$ ). The other release scenario of concern (tank dome collapse) was reviewed in Chapter 5.0 .

\subsection{OVERALL EVALUATION OF JET-PUMPING OPTIONS}

The intent of the jet-pumping program is to stabilize the wastes contained in the single-shell tanks so that the health and safety of workers and the public will be protected in a cost-effective manner. The aim of this assessment is to evaluate the options available to carry out this intent. With this in view, the benefits (reduction in doses) and costs of jet pumping to various residual heel volumes are presented in this report in terms of the radiological consequences of pumping operations, potential consequences of unplanned releases, effect on future waste disposal methods, and estimated expenditure in dollars. This information is summarized in Table 1.3. Although the single-shell tank liquid volumes and pumping cost data used in this report have changed somewhat since May 1982, the conclusions of the report are valid because the May 1982 cata base is conservative in the sense of being somewhat overestimated.

About $\$ 30$ million will be required to reduce the estimated radiation dose to the maximum individual by 1 mrem and about $\$ 70,000$ to reduce the dose by 1 man-rem to the public due to tank leaks if jet pumping is employed as a means of preventing leakage of liquids from single-shell tanks. Normally accepted upper-bound costs for public dose reduction are $\$ 1,000 /$ man-rem to satisfy as low as reasonably achievable (ALARA) needs (10 CFR 50). If this basis is used for comparison, the jet-pumping cost/benefit ratio is comparatively very high. In addition, after the $I L$ is concentrated by evaporation, it will be stored in double-shell tanks. The potential exists that the pumped riquid could at some future date contact the surrounding soil due to tank failure. Thus jet pumping by itself would not insure the reduction of dose from potential tank failure; however, if a dose were to result it would be insignificant in comparison with the dose that is caused by natural background radiation.

For these and other reasons (see details in Chapter 7.0), jet pumping is not a technically and economically practicable method of minimizing undue risks to the safety and health of the public and workers. 
Option immediately

2. Pump to $100,000-\mathrm{gal}$ limit

3. Pump to 50,000 -gal limit

4. Pump to maximum liquid removal

Comparable dose from natural background radiation

(a) 70-yr lifetime dose to the bone (critical organ).

(b) Dose to population within 50-mile radius; dose is to the bone (critical organ).

(c) 70-yr lifetime dose to the thyroid (critical organ) after 200 years when leaks reach the Columbia River.

(d) 10,000-yr integrated dose to the thyroid (critical organ) to a presumed population of 200 million.

(e) These are exclusive of doses associated with tank farm maintenance; the approximate dose rate from tank farm maintenance alone would be $0.62 \mathrm{rem} / \mathrm{yr} /$ worker.

(f) Costs associated with tank farm maintenance would be approximately $\$ 6$ million/yr (FY 1983 cost) if resumption of jet pumping option is retained.

(g) One millirem (mrem) dose is equivalent to the dose a person would receive due to cosmic radiation in approximately three days of living or in an airplane flight of 1 -hr duration.

(h) The normally accepted range is $\$ 1000 /$ man-rem reduction to meet ALARA. These costs are about 70 times higher than normal. 


\subsection{INTRODUCTION}

High-level liquid radioactive waste has been stored in underground tanks at Hanford for almost 40 years. These wastes were produced when the first plutonium production and separation operations began as part of the wartime defense effort. From 1943 to 1944, forty-eight 530,000-gal and sixteen 50,000-gal underground tanks were constructed for waste storage. The possibility of tank leaks was recognized from the start; and to minimize the consequences of possible jeaks, two sites were selected in the middle of the Hanford Reservation, far removed from the site boundaries, and on a plateau about $7 \mathrm{mi}$ from the Columbia River. The waste storage areas, about $2.5 \mathrm{mi}$ apart were designated as 200-East and 200-West. Approximately 180 to $330 \mathrm{ft}$ of very dry gravel, sand, and silt separate the waste stored in the tanks from the underlying water table. Because there are differences in soil and water-table characteristics between the two areas, each is discussed separately. The consequences of possible tank leaks are discussed in Chapter 5.0 .

As noted by Catlin (1980), the initial philosophy regarding tank design for liquid wastes relied in part on the characteristics of soil and site hydrology. These characteristics provided a natural barrier for secondary containment and consequently, led to the construction of single-shell waste tanks. The original tank design called for a concrete domed structure lined with a 1/4-in. carbon steel reinforcing rod on the sides and bottom. Later as more single-shell tanks were constructed, tank design improved to better insure their storage integrity. Liner thickness was increased to $3 / 8 \mathrm{in}$. on the bottom, and then to $3 / 8 \mathrm{in}$. on the sides as well. This design was used through 1964. Thickness of the concrete tank bottoms was also increased from the initial $6 \mathrm{in}$. to $8 \mathrm{in}$. and then to $18 \mathrm{in}$. Thickness of the bottom portion of the side walls increased from $1 \mathrm{ft}$ to $2 \mathrm{ft}$.

The lack of consequences from tank leaks to date has proven the worth of the original tank designs and the modifications to the original design; no significant radiation hazard to public health and safety has arisen from waste management operations at Hanford (Catlin 1980). Even though there has been no 
significant radiation hazard from past tank leaks, further design and construction improvements have been made. All waste storage tanks built since 1964 have been double she11; a tank within a tank, to avoid the leakage problems of singleshell tanks. But many million gallons of waste were placed in the single-shell tanks before the design was abandoned in 1964. Consequently, concern began to grow over the continuing potential for liquid waste to escape to the environment from the older single-shell tanks. Also, due to the large and everincreasing liquid waste volumes, a solidification program was begun in 1965 , to make better use of available tank storage capacity and to reduce the amount of supernatant liquids that could potentially leak. The supernatant liquids were removed from the single-shell tanks, evaporated to a slurry, and returned to the tanks for storage. This program was expanded in 1974 by the installation of two evaporator-crystallizers which has resulted in the evaporation of about 134 million gal of water, leaving approximately 38 million gal of solids containing an estimated 10 million gal of drainable IL.

Jet pumping has been proposed to remove the drainable IL from the wet solid mass left in single-shell tanks after the removal of the supernate. This process will further reduce the volume of liquid that might potentially leak from a tank, and also lessen the hydraulic head (pressure) which could force liquid out through any crack or crevice. At the conclusion of the presently proposed jet-pumping program $(F Y-1989)$, the volume of drainable liquid in single-shell tanks will have been minimized and reduce the probability of a major leak to an insignificant level,

The overriding impact associated with jet pumping will be its considerable expense. An alternative would be to reduce the actual amount of drainabie liquid volumes to be jet pumped, by scheduling shorter pumping periods, and pumping fewer tanks. This report will evaluate the health and safety consequences of various alternative jet-pumping scenarios, including the option to terminate pumping, and compare these impacts with the respective cost impacts. 


\subsection{DESCRIPTION OF CURRENT AND ALTERNATIVE JET-PUMPING PROGRAMS}

The jet-pumping program is part of a continuing effort to stabilize the HLW stored in the single-shell tanks on the Hanford Site as an interim step toward final disposal of the waste. Currently, the IL in selected single-shell tanks is scheduled for removal by jet pumping. Three reduced jet-pumping programs, including complete termination of jet pumping, have been proposed as alternatives to the current plan.

This chapter presents a description of the current and alternative jetpumping programs including:

- the present status of the single-shell tanks

- description of the jet-pumping system

- relationship of jet pumping to final disposal.

\subsection{PRESENT STATUS OF SINGLE-SHELL TANKS}

This section presents a description of the single-shell tanks at Hanford including a brief summary of their history and use; the nature of the waste stored in the tanks; the integrity of the tanks including a discussion of past leaks, potential failure modes, monitoring and surveillance of the tanks; and the role of double-shell tanks as they relate to the use of single-shell tanks.

\subsubsection{Historical Perspective}

From 1943 to 1964,149 single-shell tanks were constructed at the Hanford Site for the storage of high-ievel radioactive liquid wastes resulting from the production of plutonium for national defense purposes. Eighty-three of the tanks are located in the 200-West Area and 66 are located in the 200-East Area. They are arranged in 12 groups called tank farms which are designated by a letter of the alphabet. The number, capacity, and year the single-shell tanks were constructed are listed in Table 3.1 for each tank farm.

The single-shell tanks were constructed of reinforced concrete with flat slabs for the base, cylindrical walls, and domed tops. The sides and bottoms are lined with mild steel plate welded to form a seamless inner container, which protects the concrete from chemical attack by the waste. The domes of 
TABLE 3.1. Data on High-Level Wastes Stored in Single-Shel1 Tanks (USERDA 1975)

\begin{tabular}{|c|c|c|c|c|}
\hline$\underline{\text { Tank Farm }}$ & $\begin{array}{c}\text { Number of } \\
\text { Tanks } \\
\text { in Farm } \\
\end{array}$ & $\begin{array}{c}\begin{array}{c}\text { Capacity/Tank } \\
(\text { gal) }\end{array} \\
\end{array}$ & $\begin{array}{c}\begin{array}{c}\text { Capacity/Tank } \\
\text { (gai) }\end{array} \\
\end{array}$ & $\begin{array}{c}\text { Construction } \\
\text { Years } \\
\end{array}$ \\
\hline A & 6 & $1,000,000$ & $6,000,000$ & $1954-1955$ \\
\hline$A X$ & 4 & $1,000,000$ & $4,000,000$ & $1963-1964$ \\
\hline B & 4 & 54,500 & $6,578,000$ & $1943-1944$ \\
\hline$B X$ & 12 & 530,000 & $6,360,000$ & $1947-1948$ \\
\hline BY & 12 & 758,000 & $9,096,000$ & $1950-1951$ \\
\hline c & 4 & 54,500 & $6,578,000$ & $1943-1944$ \\
\hline $\begin{array}{l}\text { Total 200-East } \\
\text { Area }\end{array}$ & 66 & $4,457,000$ & $38,612,000$ & \\
\hline s & 12 & 758,000 & $9,096,000$ & $1950-1951$ \\
\hline$S x$ & 15 & $1,000,000$ & $15,000,000$ & $1953-1954$ \\
\hline$T$ & 4 & 54,500 & $6,578,000$ & $1943-1944$ \\
\hline$T Y$ & 6 & 758,000 & $4,548,000$ & $1951-1952$ \\
\hline U & 4 & 54,500 & $6,578,000$ & $1943-1944$ \\
\hline $\begin{array}{l}\text { Total 200-West } \\
\text { Area }\end{array}$ & 83 & $4,443,000$ & $55,444,000$ & \\
\hline TOTAL & 149 & $8,900,000$ & $94,056,000$ & \\
\hline
\end{tabular}

the tanks are not lined, however, and are exposed to the potentially corrosive atmosphere inside the tanks.

The design of the single-shell tanks improved over the years as nuclear chemical processing technology progressed and the characteristics of the waste to be stored changed. The original bismuth phosphate chemical separations process resulted in large volumes of dilute, low-heat waste that contained all the uranium and fission products present in the fuel. The uranium was eventually removed from this waste by a different process. The bismuth phosphate process was superseded by the Redox process which in turn was superseded by the present PUREX ${ }^{(a)}$ process. These latter two processes resulted in a more (a) Plutonium URanium EXtraction. 
concentrated waste with a much higher heat content that caused the liquid waste to self-boil. Consequently, storage tanks were needed that could accommodate a boiling waste. Because the majority of the heat was generated by two radionuclides, cesium-137 and strontium-90, B-Plant was converted in 1968 to remove these two radionuclides from the stored waste. However, the high-level liquid waste remaining still required cooling for about five years, before it could be converted to salt cake. Tank dimensions are 1 isted in Table 3.2 and operating parameters in Table 3.3.

TABLE 3.2. Dimensions of Single-Shell Tanks (USERDA 1975)

\begin{tabular}{|c|c|c|c|c|c|c|}
\hline Tank Farm & $\begin{array}{c}\text { Nominal } \\
\text { Inside } \\
\text { Diameter } \\
(f t) \\
\end{array}$ & $\begin{array}{c}\text { Overall } \\
\text { Height } \\
(f t) \\
\end{array}$ & $\begin{array}{c}\text { Maximum } \\
\text { Liquid } \\
\text { Height } \\
(f t) \\
\end{array}$ & $\begin{array}{c}\text { Depth of } \\
\text { Dome Below } \\
\text { Grade } \\
(\mathrm{ft}) \\
\end{array}$ & $\begin{array}{c}\text { Thickness } \\
\text { of Side } \\
\text { Plate } \\
\text { (in.) } \\
\end{array}$ & $\begin{array}{c}\text { Thickness } \\
\text { of } \\
\text { Bottom Plate } \\
\text { (in.) } \\
\end{array}$ \\
\hline A & 75 & $46^{\prime} 5^{\prime \prime}$ & 32 & 7 & $3 / 8$ & $3 / 8$ \\
\hline$A X$ & 75 & $47^{\prime} 3^{\prime \prime}$ & 32.5 & 6.5 & $3 / 8$ & $3 / 8$ \\
\hline $\begin{array}{l}B, \quad \Delta x, C, \\
T, U\end{array}$ & 75 & $31^{\prime} 9 "$ & 16 & 9 & 1/4) & $1 / 4$ \\
\hline $\begin{array}{l}B Y, S, \\
T X, T Y\end{array}$ & 75 & $37^{\prime} 10^{\prime \prime}$ & 24 & 6.2 & 4 & $3 / 8$ \\
\hline$S X$ & 75 & $45^{\prime} 11^{\prime \prime}$ & 32 & 6 & $3 / 8$ & $3 / 8$ \\
\hline
\end{tabular}

TABLE 3.3. Waste Characteristics for the Design of Single-Shell Tanks (USERDA 1975)

\begin{tabular}{|c|c|c|c|c|c|c|c|c|c|}
\hline Tank Farm & $\begin{array}{l}\text { Specific } \\
\text { Gravity }\end{array}$ & $\begin{array}{c}\text { Maxinum } \\
\text { Temperature } \\
\left(F^{2}\right) \\
\end{array}$ & $\begin{array}{l}\text { reat } \\
\text { Evolution } \\
\text { Per iank } \\
\text { BTij/hr }\end{array}$ & $\begin{array}{l}\text { Eoiling } \\
\text { Period } \\
\text { fyri }\end{array}$ & $\begin{array}{l}\text { Yapor } \\
\text { Pressure }\end{array}$ & $\begin{array}{l}\text { Initial } \\
\text { Storage } \\
\text { 'vaste } \\
\text { rolume }\end{array}$ & $\mathrm{PH}$ & $H$ & Circulation \\
\hline \multicolumn{10}{|l|}{ Nonboliting Tanks } \\
\hline$B, 8 x, C, T, U$ & 1.2 & 220 & :tegligible & itone & Sicne & 4,000 & 3 to & 010 & Sone \\
\hline$B Y, S, T X, T Y$ & 1.25 & 220 & $10^{5}$ & "one & :lone & $\div .000$ & $8: 0$ & 010 & ione \\
\hline \multicolumn{10}{|l|}{ 3oiling Tanks } \\
\hline A & 2.0 & 250 & $10^{7}$ & $j=0 \quad 10$ & CONE & 80 & 3 to & $0: 0$ & $a$ \\
\hline$A x$ & 1.3 & 250 & $10^{\circ}$ & 1 to 5 & None & 80 & 3 to & $0: 0$ & (a) \\
\hline $5 x$ & 1.35 & 250 & $10^{6}$ & $1: 05$ & itorie & 900 & 3 to & $0: 0$ & (a) \\
\hline
\end{tabular}

(a) Air-ift circulators, to concrol sludge temoerature. 


\section{1 .2 Nature of Stored Wastes}

The strongly acid wastes from the plutonium separation processes were neutralized with sodium carbonate and/or sodium hydroxide and pumped to the waste storage tanks. The neutralization process caused a complex mixture of solids to precipitate from the waste solution and form a sludge layer on the bottom of the tanks. This mass of unconsolidated solids included associated liquid a) ready referred to as IL.

By the mid-1960s, the total waste volumes accumulated had grown substantially. To reduce the volume of liquid stored in the single-shell tanks, a waste solidification program was begun in 1965, initially using circulation of heated air through the tanks, and electrical immersion heaters in the liquids. In 1973, the first of two evaporator-crystallizers was installed. The highly concentrated salt slurry from these evaporators was returned to the tanks, and upon settling produced a salt-cake layer with liquid supernate above, and $I L$ within the salt-cake matrix. The supernatant liquid was recycled for further evaporation.

The waste volume reduction and solidification program resulted in the removal of 134 million gal of water from the single-shell tanks. As of May 1982 these 149 tanks contaired approximately 11 million gal of 1 iquids including about 1 million gal of supernatant liquids with the balance $I L$, and 38 million gal of solids (both sludge and salt cake).

The 1 iquid scheduled for removal by jet pumping is contained in a 11 three layers; the sludge, salt cake, and supernate. This liquid is composed chiefly of dissolved sodium salts such as nitrate, nitrite, carbonate, aluminate, and phosphate, together with free sodium hydroxide and smal1 amounts of the hydrous oxides of iron and manganese. The composition of liquid jet pumped from the TX tank farm, 1isted in Table 3.4, provides an example composition.

The sludge layer is composed of solids that precipitated during neutralization of the high-level liquid waste. Consequently, the sludge contains most of the radionuclide fission products (including strontium but excluding cesium) and the actinides. Because different separation processes have been employed at Hanford, the characteristics of the waste tend to vary from tank to tank. 
TABLE 3.4. Representative Composition of Salt-Well Liquor (a)

\begin{tabular}{|c|c|c|}
\hline Component & Units & Average \\
\hline $\mathrm{Na}$ & $M$ & 9.72 \\
\hline $\mathrm{NO}_{3}$ & M & 3.03 \\
\hline $\mathrm{NO}_{2}$ & $M$ & 1.90 \\
\hline $\mathrm{CO}_{3}$ & M & 0.16 \\
\hline$A 7$ & $M$ & 1.36 \\
\hline $\mathrm{PO}_{4}$ & M & 0.05 \\
\hline $\mathrm{OH}$ & $\underline{M}$ & 2.99 \\
\hline $\mathrm{H}_{2} \mathrm{O}$ & $\%$ & 52.4 \\
\hline Pu & $g / L$ & $8.14 \times 10^{-6}$ \\
\hline$S r$ & $\mathrm{HCi} / \mathrm{L}$ & 456 \\
\hline
\end{tabular}

(a) From TX tank farm: jet-pumping data contained in an internal letter from D. A. Reynolds/ M. T. Jansky to S. J. Joncus, Rockwell Hanford Operations, dated June 1982.

Consequentiy, the characteristics of the sludge in each tank also vary to some extent. This is particularly true when attempting to determine if the IL contained in the sludge can be removed by pumping. A true sludge has a large capillary height and a low permeability which would prevent the IL from draining into the pump we11. However, as summarized in Kurath (1981), actual pumping experience has shown that the liquid in some sludges is drainable and, therefore, may be pumpable (see Section 3.2.1). For the purpose of selecting the 89 tanks for the current jet-pumping program, it was assumed that all the IL contained in the sludge layer in these 89 tanks would be drainable. The volume of sludge in each tank farm is listed in Table 3.5.

The salt cake lying above the sludge layer has a porosity of approximately 45 percent, occupied by IL. The ability of this IL to drain depends on the height of the liquid in the salt-cake layer to overcome the chemical and physical forces working to retain the liquid in the salt cake. Mathematical modeling (Kurath 1981) has predicted that the hydrostatic force of the liquid 
TABLE 3.5. Inventory of Single-Shel1 Tank Contents (McCann 1982)

\begin{tabular}{|c|c|c|c|c|}
\hline Tank Farm & $\begin{array}{c}\text { Sludge } \\
\text { Volume } \\
(1,000 \mathrm{gal}) \\
\end{array}$ & $\begin{array}{c}\text { Salt Cake } \\
\text { Volume } \\
(1,000 \text { gal }) \\
\end{array}$ & $\begin{array}{c}\text { Drainable } \\
\text { Interstitial } \\
\quad \text { Liquid } \\
(1,000 \text { ga } 1) \\
\end{array}$ & $\begin{array}{c}\text { Supernate } \\
\text { Volume } \\
(1,000 \text { gal }) \\
\end{array}$ \\
\hline A & 156 & 1,460 & 625 & 114 \\
\hline$A X^{\prime}$ & 26 & 878 & 355 & 25 \\
\hline B & 1,450 & 624 & 318 & 127 \\
\hline$B X$ & 1,383 & 164 & 140 & 101 \\
\hline BY & 906 & 4,721 & 1,934 & 63 \\
\hline C & 2,134 & 0 & 169 & 108 \\
\hline$s$ & 1,171 & 4,847 & 1,321 & 47 \\
\hline $5 x$ & 1,562 & 2,911 & 1,310 & 83 \\
\hline$T$ & 1,967 & 0 & 170 & 69 \\
\hline$T X$ & 263 & 7,214 & 2,253 & 20 \\
\hline$T Y$ & 590 & 68 & 58 & 11 \\
\hline U & 629 & $\underline{2,726}$ & 1,127 & 141 \\
\hline Total & 12,237 & 25,613 & 9,780 & 909 \\
\hline
\end{tabular}

in the salt cake will eventually cause all the IL to drain except the liquid in the last foot of salt cake which will be retained by capillary forces (see Figure 3.1). The estimated volume of salt cake and drainable IL contained in both the sludge and salt cake are listed in Table 3.5 for each tank farm (McCann 1982).

\subsubsection{Leaks and Leak Detection from Single-She11 Tanks}

One of the major purposes of the waste-solidification program and, subsequently, the jet-pumping program is to reduce the volume of liquid waste that could reach the environment if a tank were to leak. This section presents a brief discussion of past leaks, the monitoring system designed to detect leaks, and potential causes of tank failure.

\subsubsection{Discussion of Past Leaks}

As of May 1982, there were 26 tanks designated as confirmed leakers among the 149 single-shell tanks at Hanford (McCann 1982). Leaks have been of 


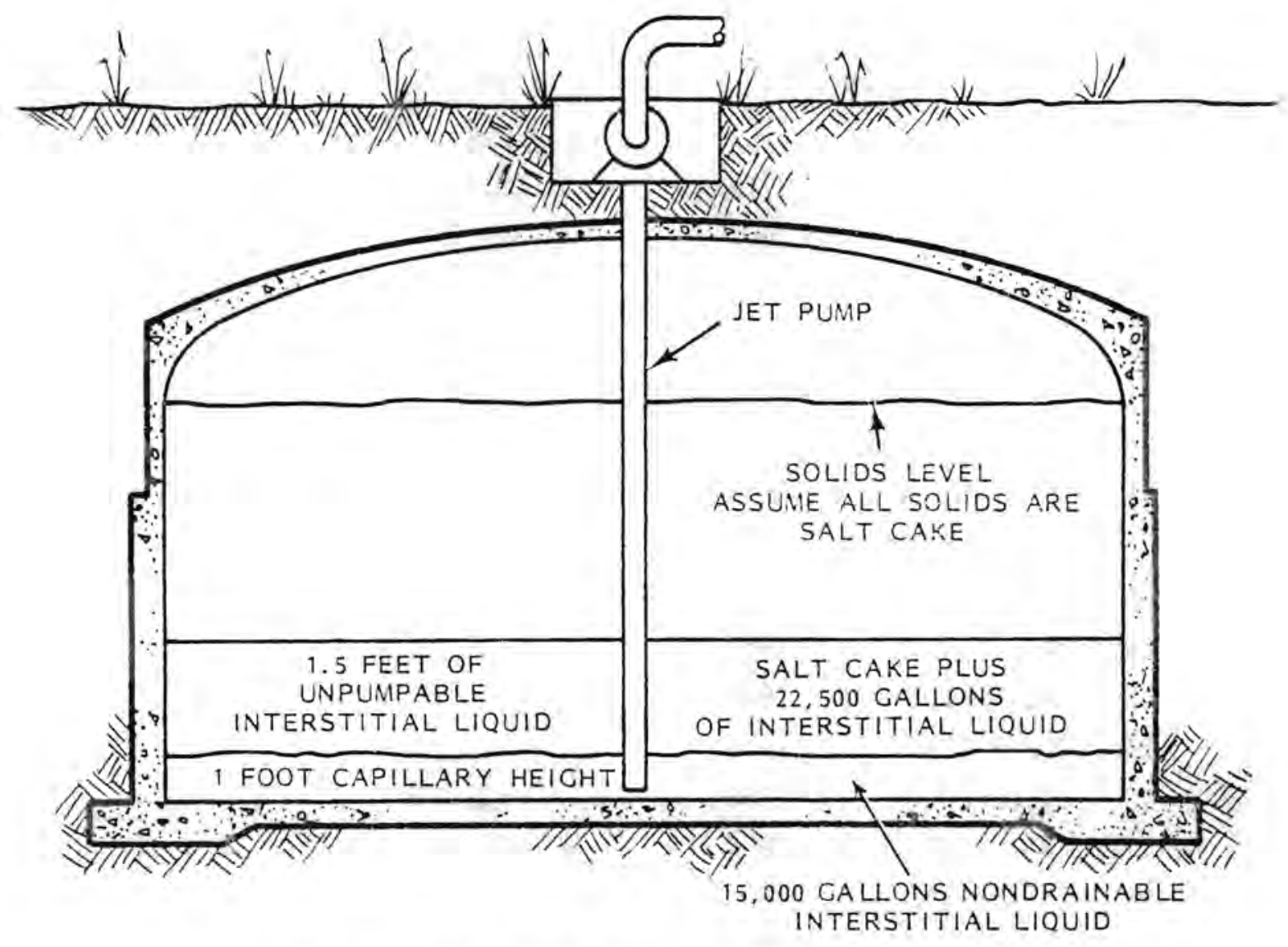

FIGURE 3.1. Tank Contents After Jet Pumping

various volumes, durations, and compositions; a listing of past leaks is shown in Table 3.6. The mitigative action taken in each case varied, but resulted in lowering the volume of drainable liquid in each tank to the feasible minimum. None of the leaks resulted in any adverse effects to workers or the general public. A description of past tank leaks and a discussion of their consequences is presented in Section 4.1 .2 of Chapter 4.0 .

An independent study (CatT in 1980) found that tank failure could not be related either to the tank size or the date of construction. However, a linear relationship was shown to exist between the active service lives of the tanks and their failure rate. It was projected that an additional 10 to 15 tanks would become unsound in the next several years. However, in the approximately nine years since the 241-T-106 leak, there have been only five confirmed leaking tanks (with a total leakage estimated to be iess than 20,000 gal) and no leaks have been confirmed since 1981 in sound tanks. 
TABLE 3.6. List of Single-Shell Tanks Confirmed as Leaking

\begin{tabular}{|c|c|c|c|}
\hline & Tank & $\begin{array}{l}\text { Year } \\
\text { Leaked } \\
\end{array}$ & $\begin{array}{l}\text { Estimäted Volume } \\
\text { Loss (gal) }\end{array}$ \\
\hline 1. & $241-U-104$ & 1956 & 55,000 \\
\hline 2. & $241-5 x-113$ & 1958 & 15,000 \\
\hline 3. & $241-T Y-106$ & 1959 & 20,000 \\
\hline 4. & $241-U-101$ & 1959 & 30,000 \\
\hline 5. & $241-T Y-105$ & 1960 & 35,000 \\
\hline 6. & $241-5 x-108$ & 1962 & 2,400 \\
\hline 7. & $241-A-105$ & 1963 & $<5,000$ \\
\hline 8. & $241-5 x-107$ & 1964 & $<5,000$ \\
\hline 9. & $241-5 x-109$ & 1965 & $<5,000$ \\
\hline 10. & $241-5 x-115$ & 1965 & 50,000 \\
\hline 11. & $241-B-107$ & 1968 & 8,000 \\
\hline 12. & $241-B-201$ & 1968 & 1,200 \\
\hline 13. & $241-C-101$ & 1968 & 17,000 to 24,000 \\
\hline 14. & $241-5 x-112$ & 1969 & 30,000 \\
\hline 15. & $241-U-112$ & 1969 & 7,000 to 10,000 \\
\hline 16. & $241-B-110$ & 1969 & 8,300 \\
\hline 17. & $241-B X-102$ & 1971 & 70,000 \\
\hline 18. & $241-B Y-108$ & 1972 & $<5,000$ \\
\hline 19. & $241-B Y-103$ & 1973 & $<5,000$ \\
\hline 20. & $241-T-106$ & 1973 & 115,000 \\
\hline 21. & $241-T Y-103$ & 1973 & 3,000 \\
\hline 22. & $241-5 x-111$ & 1974 & $<2,000$ \\
\hline 23. & $241-B X-102$ & 1974 & 2,500 \\
\hline 24. & $241-A-104$ & 1975 & 2,500 \\
\hline 25. & $241-U-110$ & 1975 & 8,100 \\
\hline 26. & $241-T Y-104$ & $1981^{(a)}$ & 1,400 \\
\hline \multicolumn{3}{|c|}{ Total Estimated Volume } & 508,400 to 518,400 \\
\hline
\end{tabular}

(a) The TY-104 tank was suspected as a leaker in 1974 and hence classified as "questionable integrity." In June 1981, it was confirmed as a leaking tank. 


\subsubsection{Monitoring and Surveillance of Single-Shell Tanks}

In addition to the 26 tanks designated as confirmed leakers, there are also 31 tanks of questionable integrity. As a result, a surveillance and monitoring program has been designed and implemented which can detect and confirm leaks. Routine activities are conducted for each tank farm including the measurement of liquid levels inside the tanks by manual or automatic methods, the surveillance of numerous dry wells located around all tanks to detect radiation, and the measurement of radiation in lateral channels installed below certain tanks in the $A$ and Sx tank farms.

A11 149 tanks have conductivity probes for the automatic measurement of any decrease or increase in liquid levels. However, a number of tanks no longer contain any supernate liquid, causing the probes to be nonfunctional except in the case of accidental liquid addition; liquid levels inside these tanks are monitored with manually operated gauges. There are more than 750 dry wells in the 200 Areas which are used to detect underground radiation. Each tank has 2 to 8 dry wells around it, located within about 6 to $10 \mathrm{ft}$ of the outer walls of the tank. The combination of liquid-level and dry-well monitoring allows a leak detection capability of approximately 2,000 to $30,000 \mathrm{gal}$ (NAS 1978). However, where only a manual liquid-level measurement capability exists and a limited number of dry wells are available around the tank, as much as 117,000 gal could leak before detection (Isaacson and Gasper 1981). Variations in liquid level can be caused by surface crusting of salt cake or sludge slumping. Rapidity of detection by radiation measurement is a function of the leak rate and the proximity of the leak to a monitoring well.

Sixteen tanks in the $A$ and $S X$ tank farms have lateral channels located approximately $10 \mathrm{ft}$ below the tanks' concrete base and extending upward along the side of the tank. These laterals allow the monitoring of radiation in a similar manner to that for the dry wells but as a function of lateral distance. A leak detection capability of about 5,000 gal is provided by these laterals. In addition, the four tanks in the AX tank farm have leak detection channels and pits in the concrete pads below them which are monitored for radiation and the presence of liquid. These pits allow detection of a leak as low as 100 gal from the bottom of the tank. 
Different monitoring frequencies are in effect both among the various types of measurements and within each type. For example, the active tanks and those containing the greatest free liquid volumes (usually these are the same tanks) are monitored more frequently for leaks, while the tanks of questionable integrity and leaker status are monitored more frequently for the inadvertent addition of unwanted liquid. A listing of the monitoring schedules for dry wells and laterals can be found in Isaacson (1981).

All data collected during monitoring are evaluated to identify potential leaks. If needed, monitoring frequencies can be increased, and in cases where a potential leak is indicated, confirmatory photographs may be taken and remedial actions (removal of supernatant liquid, emergency jet pumping, etc.) instituted.

\subsubsection{Potential Failure Modes for Single-Shell Tanks}

Many studies have analyzed the potential failure modes of the single-shell tanks at Hanford; an extensive bibliography can be found in Egger (1981). The following discussion is a brief summary of the information contained in that report.

Two types of tank failure can occur, functional and structural. Functional failure is defined as the inability of the tank to isolate its contents from the surrounding environment. Structural failure is defined as the inability of the tank to carry loads. These two types of failure can occur simultaneously or independently. Conditions contributing to tank failure include loading, material, or construction conditions.

Load conditions include:

- loads from the soil, added barriers, equipment, snow, etc. above the tank

- vertical and horizontal loads during seismic activity

- earth or water pressure outside or waste pressure inside the tank

- thermal loads caused by temperature gradients within the structure or temperature change of the tank contents

- pressure changes created by internal or external explosions, or by steam/gas generation in a sealed tank

- impact of missiles. 
Material conditions that could contribute to tank failure include:

- corrosion of the steel liner or reinforcing steel within the concrete

- degradation of the concrete from age or elevated temperatures

- bond failure between the reinforcing bars and the concrete.

Possible construction defects include:

- variances outside specified tolerances

- weakly bonded layers of concrete

- inaccurate testing of the concrete

- improper mixing of the concrete resulting in reduced strength

- improperly formed or designed construction joints

- defective welds in the steel liner.

All of the above conditions would not be expected to occur at the same time, nor would the occurrence of each individual condition be expected to result in failure. However, the combination of several conditions could result in failure ${ }^{(a)}$ of the waste tank.

\subsubsection{Role of Double-She11 Tanks}

Newer double-shell tanks now supplement single-shell tanks for storage of nigh-level liquid waste at the Hanford Site. These will be used to store the liquids removed from single-shell tanks in the jet-pumping program after evaporation and concentration to a double-shell slurry. There are currently 20 double-shell tanks, each with a 1,000,000 gal capacity, and construction has begun on eight additional tanks. The double-shell tanks are used to store not only evaporated, jet-pumped liquor but also the current acid waste, aging waste, other onsite customer waste, etc.

\subsection{DESCRIPTION OF JET-PUMPING SYSTEM}

This section includes: a description of the jet-pumping process, a discussion of the criteria used for selection of tanks to be pumped, a description of the current and proposed alternative jet-pumping termination levels, and a presentation of costs associated with each jet-pumping option.

(a) There have been no concrete structurai failures to date at either Hanford or the Savannah River Plant. 


\subsubsection{Jet-Pumping Operations}

Jet pumping is a relatively simple process that uses a modified centrifugal pump to permit very low pumping rates. The pump assembly, shown in Figure 3.2, is comprised of a tube approximately $10 \mathrm{in}$. in diameter that reaches to the bottom of the tank, with the operating equipment contained in a pump well pit located on the top of the tank. The reduced pressure created by the jetted liquid (recirculated IL) serves to remove the liquid that has drained to the bottom of the tank. The lower portion of the tube is inserted to form a salt well in the tank solids and contains slits to allow the IL to drain into the pump. The IL slowly drains into the salt well where it is removed by the pump. The height of the liquid in the salt cake provides the driving force for the flow of liquid into the salt well; with continued pumping this gradually falls so low that it is not feasible to continue jet pumping (see Figure 3.3). A final removal rate of $0.05 \mathrm{gpm}$ was chosen, partly because beyond this point excessive pumping time is required, and water additions necessary to keep the system operable become a significant percentage of the removal rate.

\subsubsection{Criteria for Selection of Tanks for Jet Pumping}

The following information is a summary of the study by Kurath (1981) that outlines the development of criteria for selection of the single-shell tanks to be pumped under the current program.

As stated previously, the height of the IL in the salt cake provides the driving force for the flow of liquid to the bottom of the tank. Properties of the salt cake and sludge that control the flow rate of the IL are permeability, viscosity, and capillary height. Permeability is the ease with which a fluid is able to pass through a material; viscosity is the resistance to shear stress exhibited by the IL; capillary height is the level of liquid at which the capillary forces balance the gravitational hydrostatic forces.

A mathematical model based on the following assumptions was developed to predict the volume of IL that would remain in a tank after the completion of jet pumping: 


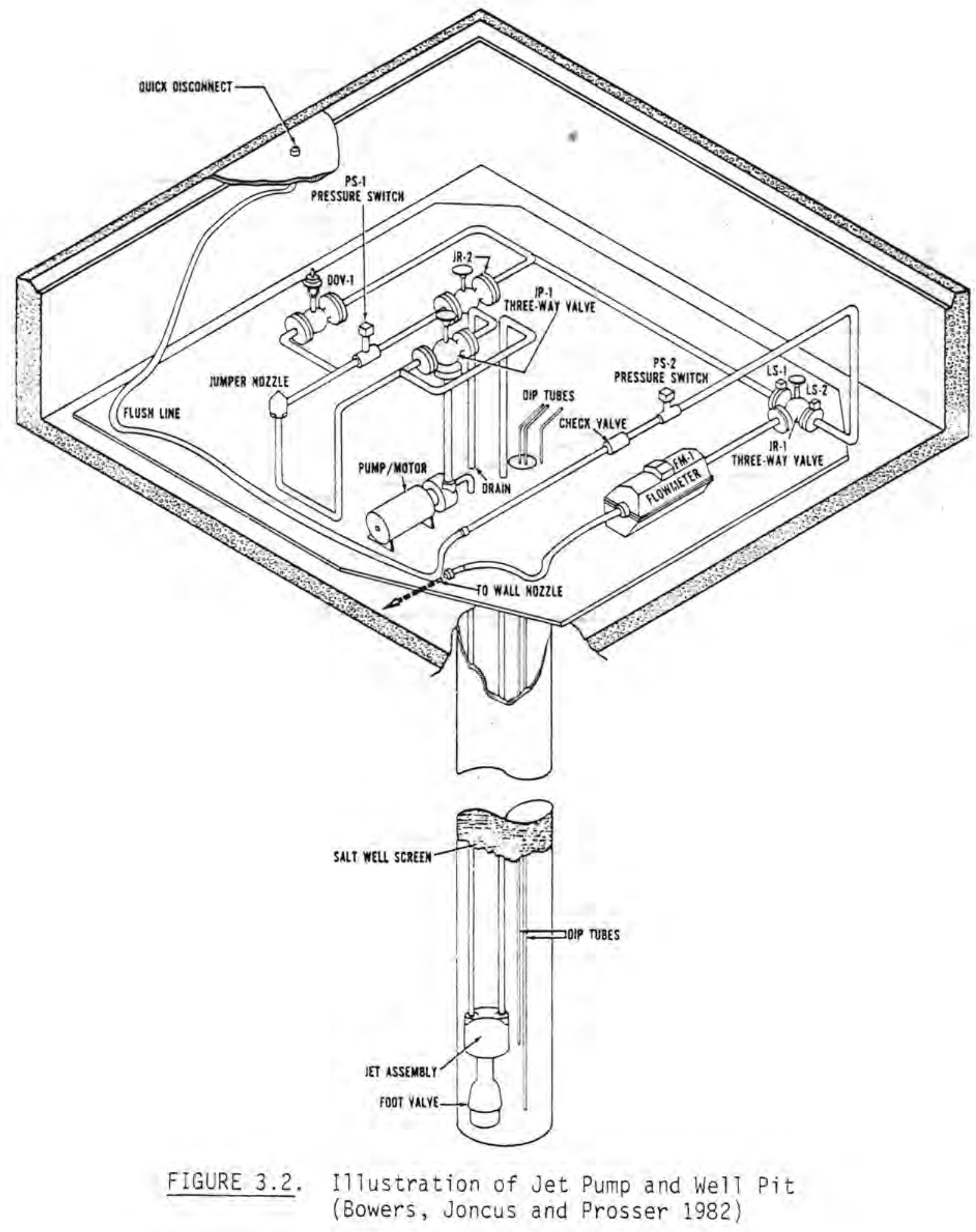




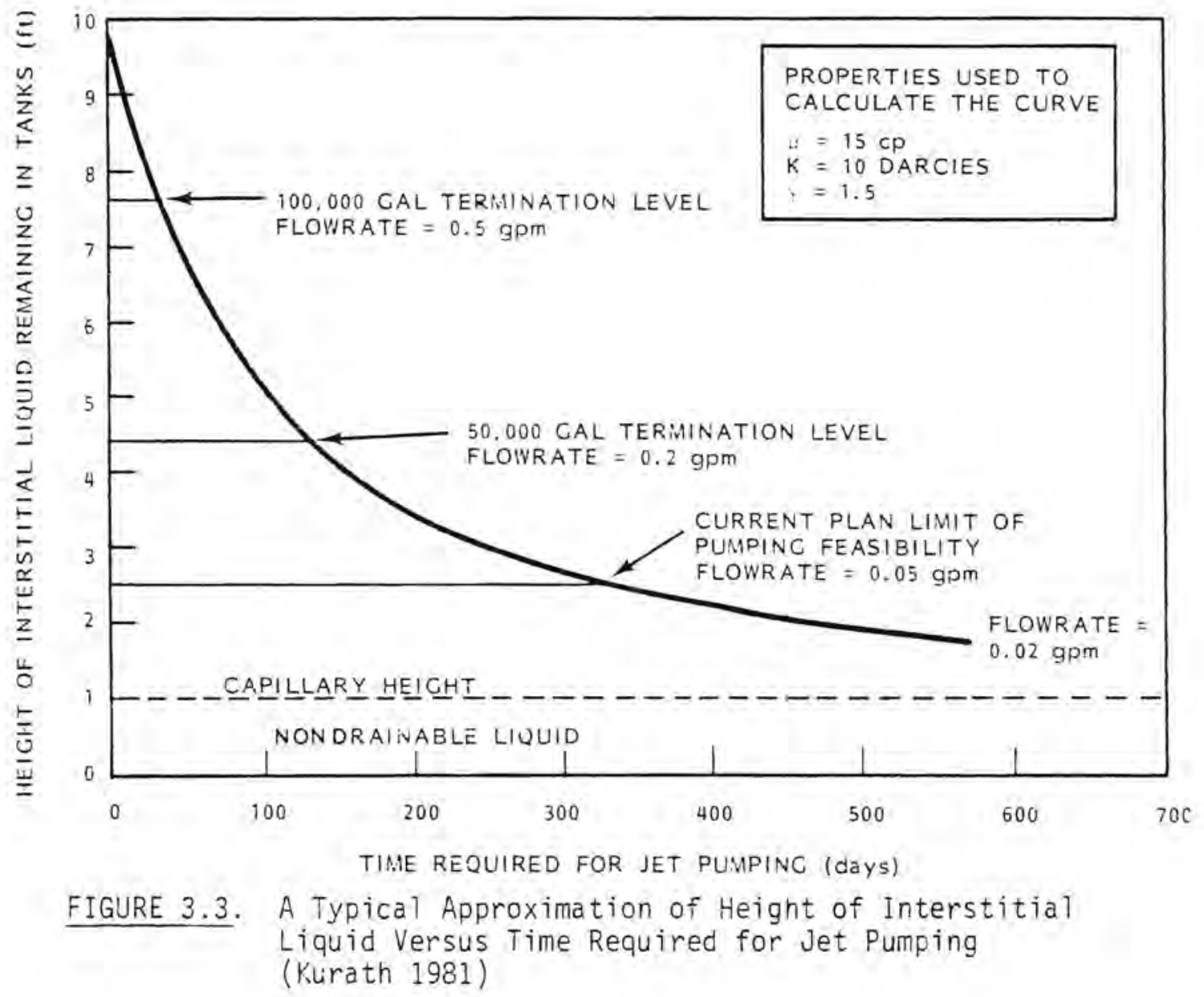

- all the solid material in the tanks would act like salt cake

- a porosity of 45 percent in the solid material

- a capillary height of $1 \mathrm{ft}$

- a minimum pumpout rate of $0.05 \mathrm{gpm}$ (a)

The model predicted that an average of $2.5 \mathrm{ft}$ of solids would still contain unpumpable IL after jet pumping. Since the 2.5-ft height corresponds to a solids volume of $82,500 \mathrm{gal}(37,000 \mathrm{gal}$ of $\mathrm{IL})$, tanks that contain less than this volume of solids would rot be scheduled for pumping. Exceptions to this

(a) The $0.05 \mathrm{gpm}$ figure is based on liquid removal efficiency, i.e., the amount of liquid removed for the time expended and for the amount of liquid added to the tank through the pumping system to prime the pump and prevent plugging. 
criterion include: tanks that contain large amounts of fission products with a heat generating capacity that could damage the tank if the liquid were removed, and tanks that contain relatively large volumes of supernate but have a solids level below the 82,500 -gal cutoff level. The latter tanks would be jet pumped to remove supernates.

\subsubsection{Current and Alternative Jet-Pumping Termination Levels and Schedules}

The current jet-pumping program follows the criterion that a 11 tanks with greater than 82,500 gal of solids will be pumped. In general, the termination volume will correspond to the IL contained in a height of $2.5 \mathrm{ft}$ of solids and a pumping rate of $0.05 \mathrm{gpm}$, the 1 imit of feasibility. A residual heel of drainable but unpumpable liquid will be held in the upper (see Figure 3.1) 1.5 ft of solids and will contain approximately 30,000 gal of liquid: 22,500 gal in the salt cake and 6,500 gal in the sludge. The liquid held in the lower (see Figure 3.1 ) $1.0 \mathrm{ft}$ of the solids is not considered drainable due to capillary forces.

Installation of jet pumps began in 1980, primarily in TX and $S$ tank farms, and pumping has already commenced. As of May 1982 the following volumes had been removed:

$\frac{\text { Tank Farm }}{\text { Volume Removed }} \quad \frac{\mathrm{S}}{793,000 \mathrm{gal}} \quad \frac{\mathrm{TX}}{772,000 \mathrm{gal}} \quad \frac{\mathrm{BY}}{56,000 \mathrm{gal}}$

The status of jet-pumping equipment installation as of the end of May 1982 is shown in Table 3.7 .

The three proposed alternative jet-pumping termination levels considered in this report would be reached at residual heels of 100,000 gal or 50,000 gal of drainable 1iquid, or complete termination of the jet-pumping program. A comparison of residual heel volumes for the four options is shown in Table 3.8 .

The proposed increase in the termination volume to either 100,000 gal or 50,000 gal would result in a significantly decreased number of tanks scheduled for pumping. This reduction would result in a shorter pumping schedule, reduced labor needs, and lower program costs as shown in Table 3.9. Termination of the jet-pumping program could not be expected to occur before midFY 1983. The effect of reduced or discontinued jet pumping on present and potential radiological consequences is discussed in Chapters 4.0 and 5.0 . 
TABLE 3.7. Status of Jet Pumping Equipment Insta17ation as of May 1982 (McCann 1982)

\begin{tabular}{|c|c|c|c|c|}
\hline Tank Farm & $\begin{array}{l}\text { Number of Tanks } \\
\text { to be Pumped }\end{array}$ & $\begin{array}{c}\text { Jet Pumps } \\
\text { with Salt-Well } \\
\text { Screen Installed } \\
\end{array}$ & $\begin{array}{l}\text { Salt-Well } \\
\text { Screens } \\
\text { Installed } \\
\end{array}$ & $\begin{array}{l}\text { Liquid Observation } \\
\text { Wells Installed }\end{array}$ \\
\hline A & 2 & 0 & 2 & 0 \\
\hline$A X$ & 2 & 0 & 2 & 0 \\
\hline B & 9 & 0 & 7 & 0 \\
\hline$B X$ & 6 & 0 & 5 & 0 \\
\hline BY & 12 & 1 & 10 & 1 \\
\hline c & 6 & 0 & 4 & 0 \\
\hline S & 12 & 8 & 10 & 3 \\
\hline $5 x$ & 6 & 0 & 5 & 1 \\
\hline$T$ & 7 & 0 & 6 & 0 \\
\hline$T X$ & 15 & 15 & 15 & 6 \\
\hline$T Y$ & 3 & 0 & 2 & 0 \\
\hline U & 9 & 0 & $\underline{2}$ & $\underline{0}$ \\
\hline Total & 89 & 24 & 70 & 11 \\
\hline
\end{tabular}

A histogram depicting the numbers of tanks with varying volumes of drainable liquid is shown in figure 3.4. The distribution shows that the bulk of the liquid available for pumping is found in a relatively small number of tanks with greater than 100,000 gal of drainable liquid, and that reducing the cutoff to 50,000 gal does not greatly increase the quantity of liquid removed.

The estimated pumping schedules for the three jet-pumping termination levels are shown in Figure 3.5. These schedules are not based on detailed considerations such as daily liquid removal rates or individual pump installation times and therefore could vary with pumping experience.

The following assumptions, made in developing the schedules shown in Figure 3.5 are discussed further below:

- the current schedule would be followed until a decision to change the pumping program was made; this is assumed to occur no sooner than mid$\mathrm{FY}-1983$ 
TABLE 3.8. Comparison of Residual Drainable Interstitial Liquid Volumes at Varying Termination Levels in Thousands of Gallons (McCann 1982)

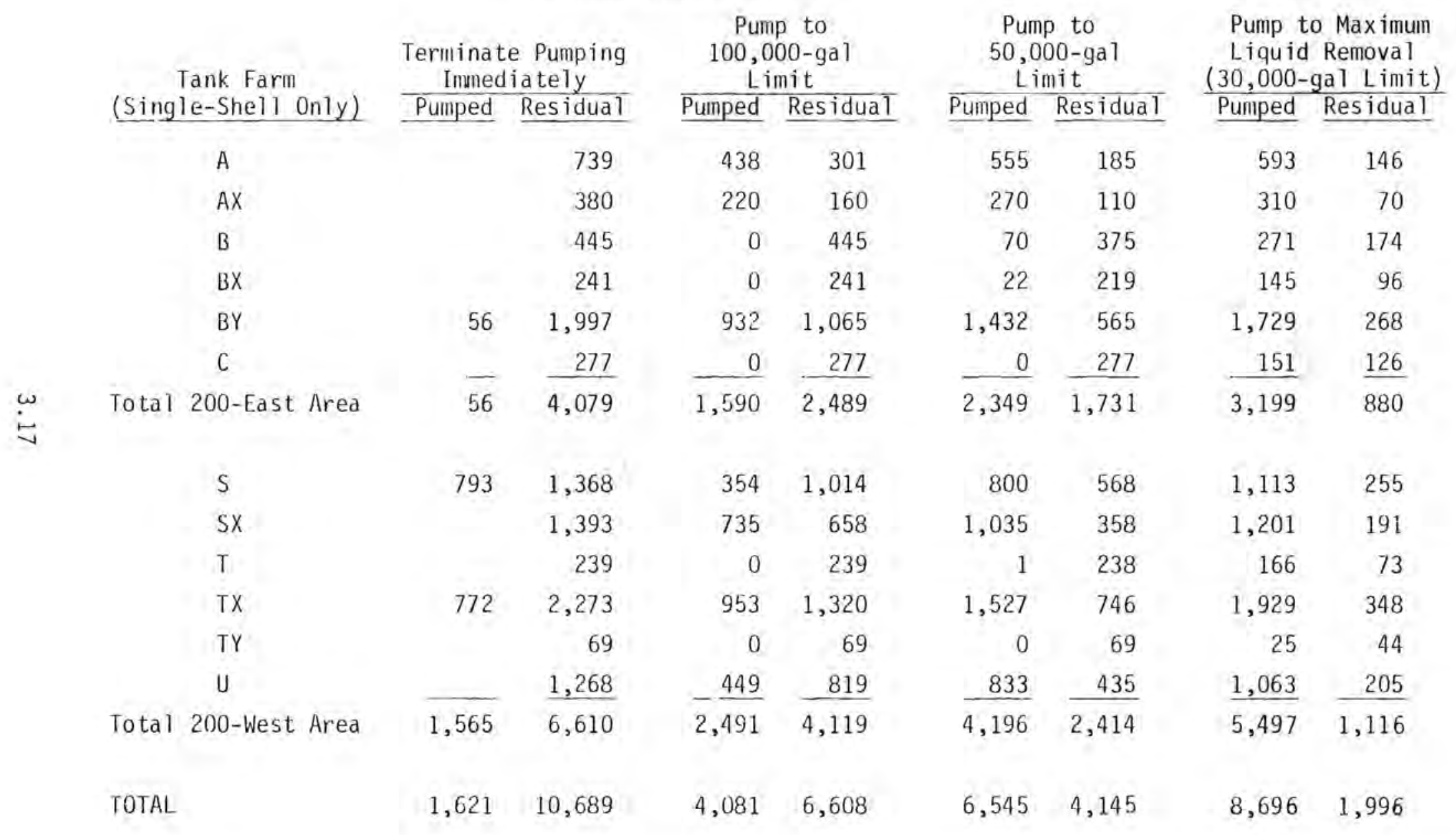


TABLE 3.9. Comparison of Current and Alternative Jet-Pumping Termination Levels

\begin{tabular}{lcccc}
\multicolumn{1}{c}{ Option } & $\begin{array}{c}\text { Estimated } \\
\text { Completion } \\
\text { Year }\end{array}$ & $\begin{array}{c}\text { Number of } \\
\text { Tanks Pumped }\end{array}$ & $\begin{array}{c}\text { Labor } \\
\text { (man-yr) }\end{array}$ & $\begin{array}{c}\text { Estimated } \\
\text { Costs FY-1983 } \\
\text { (thousands of \$) }\end{array}$ \\
$\begin{array}{l}\text { Terminate Pumping } \\
\text { Immediately }\end{array}$ & 1983 & 25 & NA (a) & NA \\
$\begin{array}{l}\text { Pump to 100,000-gal } \\
\text { Limit }\end{array}$ & 1986 & 47 & 472 & 73,000 \\
$\begin{array}{l}\text { Pump to 50,000-ga1 } \\
\text { Limit }\end{array}$ & 1987 & 55 & 611 & 102,000 \\
$\begin{array}{l}\text { Pump to Maximum } \\
\text { Liquid Removal } \\
\text { (30,000-gaT Limit) }\end{array}$ & 1989 & 89 & 1125 & 160,000
\end{tabular}

(a) $N A=$ Not applicable.

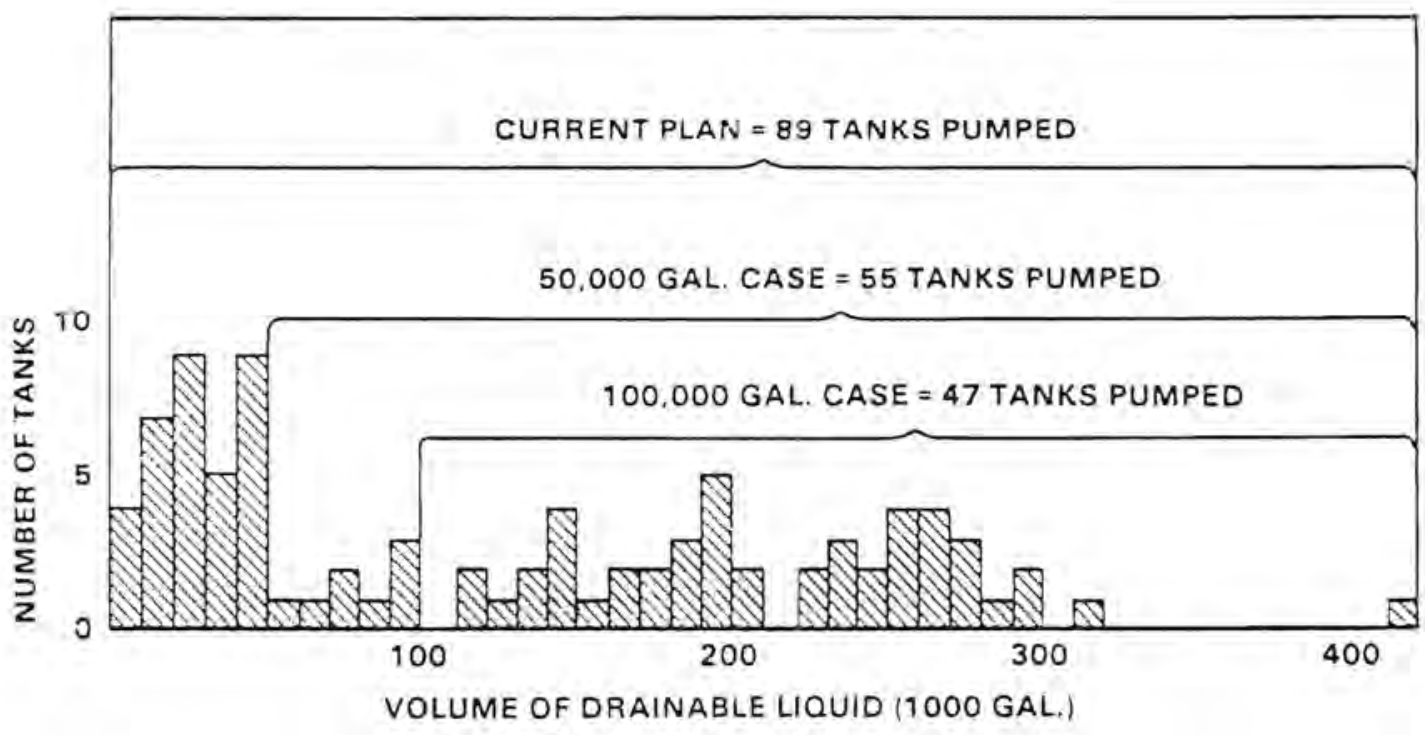

FIGURE 3.4. Histogram of Drainable Liquid Volumes Contained in Single-Shell Tanks 
CURRENT PROGRAM (AS OF AUGUST 1982)

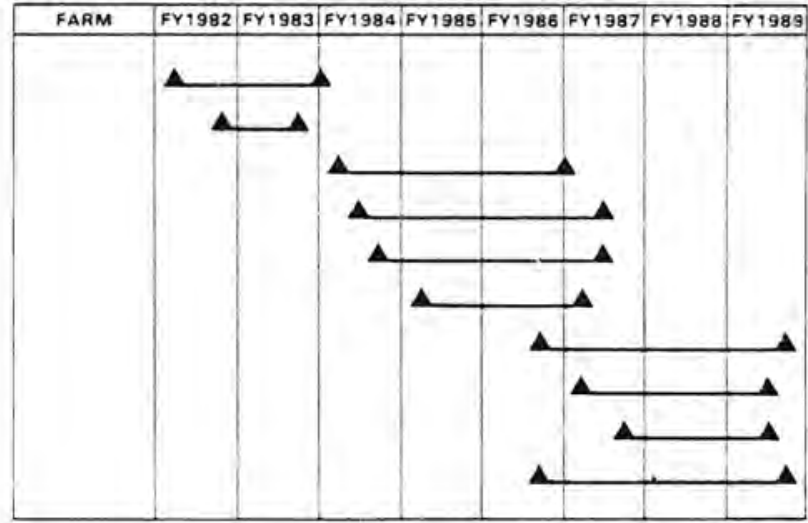

50,000 GALLON LIMIT

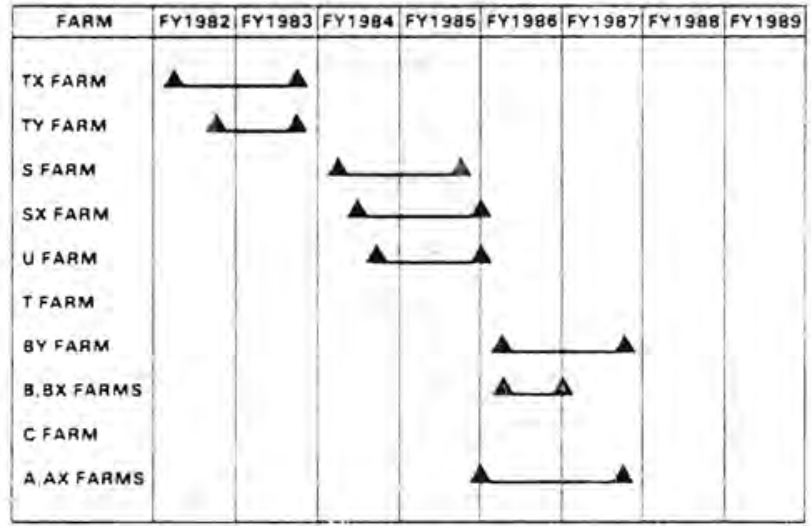

100,000 GALLON LIMIT

\begin{tabular}{|c|c|c|c|c|c|c|c|c|}
\hline FARM & FY1982 & FY1983 & FY 1984 & 4 FY1985 & FY1986 & FY 1987 & FY 1988 & FY1989 \\
\hline TXFARM & $\Lambda$ & A & & & & & & \\
\hline TY FARM & $\Lambda$ & $\Delta$ & & & & & & \\
\hline SFARM & & & $\Delta$ & & & & & \\
\hline SXFARM & & & $\Delta$ & A & & & & \\
\hline UFAAM & & & $\mathbf{A}$ & A & & & & \\
\hline TFARM & & & & & & & & \\
\hline BYFARM & & & & & $\Lambda$ & A & & \\
\hline B.BX FARMS & & & & & & & & \\
\hline CFARM & & & & & & & & \\
\hline A. AXFARMS & & & & & $\Lambda$ & $\Delta$ & & \\
\hline
\end{tabular}

FIGURE 3.5. Effect of Alternative Jet Pumping Termination Levels on Time Schedules (Letter from K. A. Gasper, Rockwell Hanford Operations to K. S. Murthy, Pacific Northwest Laboratory, dated August 1982) 
- the current schedule cannot be shortened due to 1 imited double-shel1 tank space for the liquid removed

- for the reduced pumping schedules, no tanks will be pumped with drainable liquid volumes less than 100,000 - or 50,000-gal limits

- for the reduced pumping schedules, pumping will be terminated when the 100,000 - or 50,000-gal 1 imit is reached.

The first assumption results in the pumping of the TY tank farm in all three cases despite a drainable liquid volume of less than 50,000 gal. The second assumption is caused by the current construction schedule of the new doubleshell tanks which calls for completion in mid-FY 1986. However, the resultant extension of the current pumping schedule will permit a more efficient use of workers because the pumping schedule for the last four tank-farm sets does not greatly overlap that of the previous tank farms (see Figure 3.5 ). The last two assumptions are simply an application of the new criterion with the exception of the TY tank farm as already noted.

As stated previously, the option to terminate jet pumping would not be expected to occur before mid-FY 1983. At that time an orderly shutdown of the jet-pumping program would begin; the shutdown cost is estimated to be approximately $\$ 1$ million.

\section{2 .4 Costs}

The estimated costs (shown in Table 3.10) for completion of each jetpumping option are compared graphically in Figure 3.6. Like the schedules, these costs are based on limited pumping experience, and are therefore, approximate. The bases and assumptions for calculating costs for each option are similar; thus, internal variations are common to all cost figures, and hence do not influence the comparisons.

The following assumptions were used in estimating the costs:

- costs include FY-1983 through completion of jet pumping and tank isolation; interim isolation requirements wi11 remain constant for a) 1 options 
TABLE 3.10. Estimate of Tota] Program Costs for Jet-Pumping (a)

Options (in thousands of dollars) as of 1983

\begin{tabular}{|c|c|c|c|c|c|c|}
\hline Qption & $\begin{array}{l}\text { Basic Program } \\
\text { and Maintenance } \\
\end{array}$ & $\begin{array}{l}\text { Jet-Pumping } \\
\text { Startup } \\
\end{array}$ & $\begin{array}{l}\text { Jet Pumping } \\
\text { Operational }\end{array}$ & Evaporation & $\begin{array}{l}\text { Double-She } 11 \\
\text { Tank Storage }\end{array}$ & TotaT \\
\hline $\begin{array}{l}\text { Pump to } 100,000-\text { gal } \\
\text { Limit }_{\text {im }}(b)\end{array}$ & 21 & 2 & 18 & 3 & 29 & 73 \\
\hline $\begin{array}{l}\text { Pump to } 50,000 \text {-gal } \\
\text { Limit(c) }\end{array}$ & 26 & 2 & 24 & 4 & 45 & 102 \\
\hline $\begin{array}{l}\text { Pump to Maximum (d) } \\
\text { Liquid Removal } \\
(30,000 \text {-gal Limit) }\end{array}$ & 36 & 3 & 51 & 4 & 60 & 160 \\
\hline
\end{tabular}

(a) Letter from K. A. Gasper, Pockwell Hanford Operations to K. S. Murthy, Pacific Northwest Laboratory dated Augusted 1982 :

(b) Ending 1986

(c) Ending 1987

(d) Ending 1989

- costs do not include funding for tank-farm cleanup, surface stabilization, or additional tank dome stabilization

- costs of capital funding support for jet pumping and tank isolation will not vary significantly

- the pumping schedules shown in Figure 3.5 will be followed

- costs do not include funding for monitoring and survejliance programs for environmental control; these costs would be relatively constant for a1T options.

In addition to these assumptions, the jet-pumping and tank-isolation costs are also consistent with the composite pricing assumption used in Bowers et al. (1982). This assumption based cost data on a composite of actual jet-pumping operational costs and a detailed cost estimate extrapolated over the duration of the pumping aiternative.

Figure 3.6 indicates that the costs for jet-pump startup and evaporation are small relative to the total costs. Startup costs are low because construction of the jet-pump systems will be essentially complete by early FY-1983 and no startup cost savings would be made by reducing the pumping schedule. The evaporator costs are also low because they were considered as an incremental 


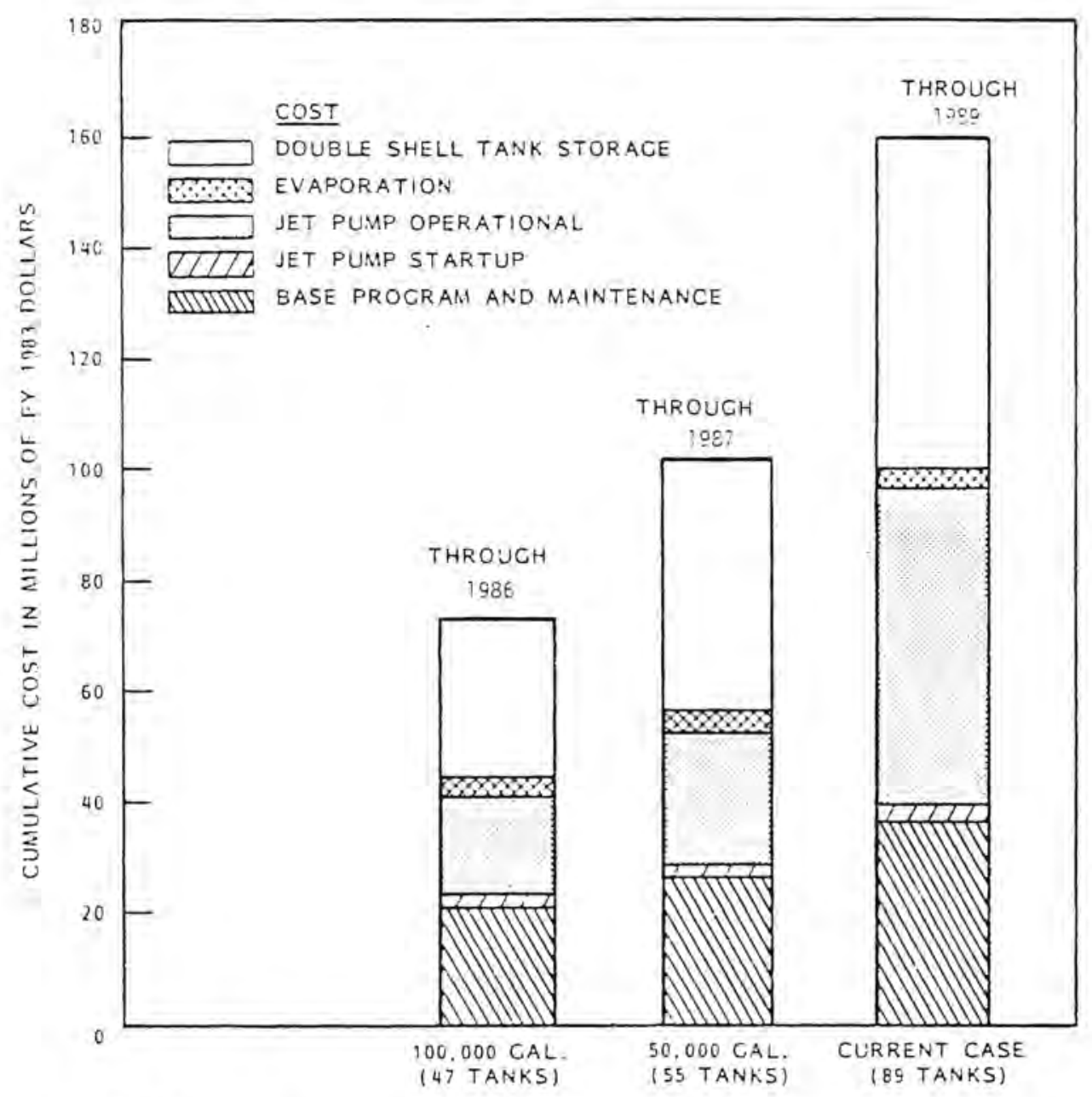

FIGURE 3.6. Cost Comparison of Jet-Pumping Options

addition to an ongoing evaporation operation. The base program and maintenance costs include routine support and facilities' maintenance along with the cost of supporting the pumping program and the cost of single-shell tank storage. Storage costs for the double-shell tanks are based on the cost of replacing the storage space used in the tanks. This method was used because the doubleshell storage tanks are used by other programs on the Hanford Site for other waste management purposes.

If the jet-pumping program were completely terminated, the annual cost of routine tank farm operations (e.g., facility maintenance) would be 
acproximately $\$ 5$ million/yr, FY-1983 costs. Similar costs would also be applicable to the three jet-pumping options upon completion of the pumping program. Tank-farm maintenance costs would continue at least until such time as final disposal of the tank waste is completed. Again, this cost does not include maintenance of monitoring and surveillance programs used for environmental control.

\subsection{RELATIONSHIP OF JET PUMPING TO FINAL DISPOSAL}

Jet pumping is an interim step toward final disposal of high-level tank wastes, designed to minimize the possibility and the consequences of tank leakage during the short term, until final disposal is implemented.

Two final disposal methods are being considered for HDW, in-situ and geologic disposal. However, discussion of the relationship of jet pumping to disposal is complicated by the fact that the preferred disposal method for HOW has not been defined, and it may well be that different techniques would be selected for different waste tanks, depending on the particular circumstances and tank contents.

Specific in-situ and geologic disposal techniques; described in Sections 3.3 .1 and 3.3 .2 , respectively; were studied to determine their compatibility with the four jet-pumping options. None of the disposal techniques would be precluded by adoption of any of the jet-pumping options. (a) However, since techniques for final disposal are still in the experimental/demonstration stage, the optimum level of liquid waste remaining in a tank prior to implementation of in-situ or geologic disposal has not be determined.

\subsubsection{In-Situ Disposal Methods}

In this approach, the wastes would be left in the underground tanks in which they are now stored, and additional engineered barriers would prevent the loss of contents or human access. The techniques for in-situ disposal discussed in this section are all used for stabilizing the waste in the tanks. Also, since the concrete tank domes constitute a potential structural failure

(a) For the particular case of complete termination of jet pumping, disposal would become an "alternative" to jet pumping rather than a subsequent step following jet pumping. 
problem, any planned in-situ disposal methodology includes filling the dome voids with material to reinforce the tank dome and walls during subsequent disposal steps (Rockwell 1982).

Feasible approaches to stabilizing the waste preparatory to in-situ disposal currently appear to be restricted to methods involving water removal by drying or by chemical combination. Five of these approaches: resistance heating, microwave heating, air sweep, in-situ vitrification, and solidification, are briefly described below.

\subsubsection{Resistance Heating}

In this process, heat is generated by passing an ac current between electrodes in the tank to raise the tank contents to about $250^{\circ} \mathrm{F}$. At this temperature water will migrate as vapor from the bottom part of the tank into the vapor space and will be swept away by the air flow. Potential difficulties with this process include heat transfer through the waste, diffusion of the vapor up through the mass of salt cake and sludge, and possible conversion of the salt cake to a hard cohesive mass which would be much more difficult to remove at a later date from the tank (should this become necessary).

\subsubsection{Microwave Heating}

This process is similar to the resistance-heating process except that the necessary heat is supplied by microwave radiation. The bulk of the tank contents would be heated to about $250^{\circ} \mathrm{F}$ to drive the water to the surface to be swept away. Similarly, this process has the same potential difficulties as the resistance-heating process.

\subsubsection{Air Sweep}

This process in its simplest form would consist of sweeping air across the surface of the tank contents. Removal of water at an appreciable rate would probably occur only if the tank contents were warm enough for adequate diffusion of water vapor to the surface to occur. However, it is not known whether a sufficiently large air flow through the salt cake/sludge could be established in order to move the water vapor to the surface. 


\subsubsection{In-Situ Vitrification}

This approach would take the resistance heating process one step further, i.e., adding glass-formers to the waste and heating to the point of vitrification. This process, described in Brouns and Timmerman (1982) has not been demonstrated for an in-tank situation. Areas of potential difficulty in implementation of this process include the possible effect of vitrification temperatures on the chemical stability of the waste and the resultant immediate impact on integrity of the concrete tank and its steel liner.

\subsubsection{Solidification}

In this process the waste is mixed with clay and/or cement to form a mixture that will set up in a water-free form after its return to a tank. The major drawback of this process is the need to remove the waste from the tanks in order to adequately mix the clay/concrete with the wastes to ensure a final waste form that is stabilized. In this process, the final volume of the solidified waste would be about four times the original volume. This is not necessarily a disadvantage since in-situ disposal requires that material be added to the tanks for dome support.

\subsubsection{Geologic Disposal Methods}

In this approach, the wastes would be placed in a geologic repository excavated using conventional mining techniques. Again, the waste would be in a stabilized form and in containers designed to meet repository criteria. The DOE has decided to construct a large defense waste processing facility at the Savannah River Plant (SRP) (47 FR 23801) for the integrated processing of sludge and salt cake to form:

- borosilicate glass for geologic disposal in a federal repository

- decontaminated salt for disposal at SRP as low-level waste.

A similar scheme could be considered for the single-shell tank wastes at the Hanford Site. Both of these two final waste forms would be compatible with any of the jet-pumping options or with the option to terminate pumping. However, while the wastes could be processed without jet pumping, they could not be processed immediately, as the necessary processing facility does not exist at Hanford and could not be designed and built for several years. 



\subsection{DISCUSSION OF RELEASE SCENARIOS AND RADIONUCLIDE TRANSPORT}

Scenarios for release of radioactive wastes from the single-shell tanks to the soil or the atmosphere environments need to be studied (in an attempt) to analyze the various options available for waste management. This is often done by postulating a sequence of events that lead to a release or release scenario. It is important to distinguish events from scenarios because single events do not always supply a mechanism for waste release, and al though the probability of an event occurring exists, it does not necessarily mean a release scenario will take place. To adequately analyze the impacts of jet pumping (Chapter 5.0), a number of release scenarios are described that are believed to have some bearing on the desirability of terminating pumping immediately or pumping to preselected levels. Those scenarios addressed are tank leaks, tank dome collapse, and a group of "generic" release scenarios.

\subsection{TANK LEAKS}

Twenty-six of the 149 existing single-shell tanks have developed confirmed leaks of various sizes. The existence of these leaks and the possibility of future leaks was the primary reason for initiating the jet-pumping program. The intent of this section is to determine the importance (consequence) of these leaks and potential future leaks as a function of the pumping termination volume chosen. A brief discussion of the historical leaks is included in the discussion to provide some insight into the overall problem.

\subsubsection{Transport Models}

Leakage of drainable liquid into the soil from the Hanford single-shell waste tanks is a likely event and considerable effort has been expended through modeling efforts to predict the transport and consequences of leakage.

For this study the assumption was made that all of the tanks leak over a short period and all of the drainable liquid escapes to the unsaturated zone. This is a "worst-case" situation because it is expected that the tanks will begin leaking over a period of several decades and each tank will leak at a rate of about $0.03 \mathrm{gal} / \mathrm{min}$ into the unsaturated zone (Isaacson and Gasper 1981). 
The basic hydrogeology of the Hanford Site has been described in detail and is well documented. The Final Environmental Statement on Waste Management Operations (USERDA 1975) contains a summary of much of the available hydrogeologic data as well as descriptions of the major models available to predict ground-water transport. A detailed description of the particular geology below the 200-East and 200-West Area tank farms is included in Brown (1960), Tallman (1980), Graham (1981a,b), Wilbur and Graham (1982), and Price and Fecht (1976a-1). The physical and chemical properties of the sediments underlying the tank farms retard the movement of leaked radionuclides to the water table. These properties are adsorption, a low initial moisture content, thickness of the unsaturated zone, and layering which enhances lateral spreading. The physical and chemical properties of the saturated zone and the flow dynamics of the aquifer further delay transport and reduce contaminant concentrations. These properties could provide an impediment to the transport of leaked materials through the saturated and unsaturated zone.

Many of the radionuclides are permanently bound in the tank salt cake and sludge as insoluble compounds or complexants and are not available for transport in the event of a leak. (a) Only intrusions of large amounts of water could alter the chemical balance within the tanks and leach additional radionuclides. The major radionuclides of concern which can be transported out of the tank are technetium-99, ruthenium-106, strontium-90, cesium-137, and neptunium-237. Plutonium is also of concern. However, experience at Hanford has shown that plutonium in slightly acid to basic solutions (waste is highly basic) does not migrate more than about $3 \mathrm{ft}$ into the sediments from the point of release (ARHCO 1973). Other radionuclides such as europium-155, europium-154, cerium144, antimony-125, cobalt-60 and other rare earths are either highly sorbed in

(a) As of July 1982 an estimated $33 \mathrm{MCi}$ (16 percent of the total curies in single-shell tanks) were present in the total drainable IL compared to an estimated $200 \mathrm{MC} i$ in the entire 149 single-shell tanks. Radionuclides contributing to the $33 \mathrm{MCi}$ in the liquids are: $31 \mathrm{MCi}$ of cesium-137, $2 \mathrm{MC} i$ of strontium-90 and smaller amounts of technetium-99, iodine-129 and neptunium-237. Estimated americium-241 in the liquids in $0.05 \mathrm{Ci}$ compared to $9,300 \mathrm{Ci}$ in the salt cake plus sludge. The americium-241 content in smoke detectors (about 100 million units in use) may be estimated at $500 \mathrm{Ci}$ in the United States based on a $5 \mathrm{LCi} /$ detector (NCRP 1977). 
the soil or have short half-lives and are not of concern with regard to transport to the Columbia River. It is possible that some tanks may contain small amounts of americium-241 in complexed form. Adequate quantitative data are not presently available to completely evaluate the mobility and transport of this nuclide. The available information indicates that the small quantities of this nuclide combined with the expected retardation will not result in any significant contribution to the overall dose consequences, even if the nuclide reached the river. Work is presently underway at Rockwell to quantify the amounts of americium-241 in the tanks.

The nature of the sediments which inhibit movement of radionuclides and the patterns and rates of ground-water movement are well documented and investigations are continuing. The results available before 1974 were reviewed in ERDA-1538 (USERDA 1975). Additional material is available in a National Academy of Sciences-National Research Council study panel (NAS 1978) and in work directed toward reducing the number of uncertainties about the hehavior of fluids added to the unsaturated zone (Brownell et al. 1975; Arnett et al. 1977; Routson et al. 1979). The movement of ground water beneath the Hanford tank farms has been investigated (Arnett et a 1. 1977) as well as the mechanism of sorption of waste constituents on soils (Routson et àl. 1973, 1978, 1981; Mercer 1967; Routson 1973; Routson, Barney and Smith 1980, 1981).

The scope of this study (involving all single-sheil tanks) and the limited data readily available precluded the rigorous mathematical modeling of liquid flow and radionuclide movement through the unsaturated zone.

Rather than direct modeling, the approach taken for the investigation was to utilize extensive historical records and data which exist for disposal of wastes in cribs $(a)$ at the Hanford Site and subsequent direct measurement of ground-water contamination. Thus, the actual data from disposal of wastes can be used to directly predict the movement of the radionuclides through the unsaturated zone to the water table.

It is assumed that the use of crib data as a surrogate for tank leak data is reasonable and provides a physical model of a tank leak and actual

(a) Certain 1 iquid effluents were released to the ground via underground structures called cribs. These are described in detail in USERDA (1975). 
radionuclide transport. Both the cribs and tank farms are located in the same general vicinity, and migration of radionuclides from the cribs to the saturated zone is similar to that from a tank leak.

Crib selection was based on crib volumes, inventories, physical locations, and the adequacy of nearby well-monitoring data. In most cases, the selected cribs receiving high-salt wastes were used because of their similarity to IL in the single-shell tanks (i.e., similar to what might leak from the tank).

The crib data consists of the:

- quantity of fluid discharged to the cribs

- period of discharge to the cribs (estimated)

- discharge inventory of nuclides in curies

- location of crib and depth to the ground water

- location and depth of nearby monitoring wells

- contamination history of nearby wells.

There are many monitoring wells that are situated adjacent to or within $100 \mathrm{ft}$ of the disposal cribs (Graham 1981; Wilbur and Graham 1982). Consequently, the contamination data analyzed from the well samples represents breakthrough (time for individual nuclides to reach the well) concentrations of nuclides traveling through the unsaturated zone. The well contamination data contain in integrated form, the transport parameters of dispersion, retardation, and water velocity for the unsaturated zone.

The objective was to use existing, well defined data to estimate average soil parameters which could be used to predict the movement of radionuclides to the ground water from tank leaks in the 200-East or 200-West Areas. The approach estimated value for the various parameters of a one-dimensional, convective-dispersion model by using the measured data on discharges of radionuclides and liquids to disposal cribs, and subsequently measured the time to breakthrough (when specific radionuclides become detectable) at nearby monitoring wells.

The assumption made is that during infiltration (disposal), the pulse of radionuclides advances with some constant average velocity. Any remaining variations can be described by an effective dispersion coefficient, which is 
determined by fitting a "breakthrough" function to the concentration versus time data obtained from the monitoring wells. This dispersion coefficient is determined by using standard nonlinear least square curve fitting programs which fit the conceptual transport model to the experimental data. The actual program (model) employed is described in detail in Van Genuchten (1981). The model is "calibrated" by fitting to the experimental curves for the very-mobile and nonabsorbed radionuclide, ruthenium-106 discharged to the cribs.

Ruthenium-106 with a half-life of one year has been shown to move (essentially with the water) through soil columns of varying compositions (Coles and Ramspott 1982; Ames and Rai 1978). The remaining beta-emitting radionuclides (i.e., strontium-90, cesium-137, rare earths, etc.) are known to be held up in the soil by absorption mechanisms which greatly retard (or stop) their movement.

The well monitoring data indicate that the beta-emitting radionuclides arrived at the water table approximately one to three years after discharge to the cribs. Any contribution to the observed total beta counting at the monitoring wells for nuclides other than ruthenium-106 can be easily detected. Actual data indicate that the total beta count observed in the wells is primarily due to the ruthenium-106 alone. Van Genuchten's program does not consider radioactive decay, so all of the breakthrough data was corrected for the ruthenium-106 half-life depletion prior to fitting the model to the data.

The lack of dimension for the parameters used in Van Genuchten's program required that observed concentrations of ruthenium breakthrough curves be expressed relative to the initial concentration of solution entering the crib. In several cases it was not possible to directly determine the initial waste concentration entering the disposal crib. To overcome this difficulty, Van Genuchten's program was modified to provide an estimate of the initial concentration. An iterative process was used where at the end of each curve fit, the concentration was adjusted until the sum of the squares of residual between the observed and predicted concentrations was minimized.

Another problem to overcome was to determine the starting time of the actual pulse release of radionuclides to the crib, since this was not accurately specified in the data in many cases. This was necessary because decay corrections are based on this time; and because velocity, dispersion, and retardation 
estimates would be affected by this input. Two independent methods of estimating the flow velocity were used and the program was run varying the initial pulse release times until consistent estimates for water velocity were obtained using both methods.

Each data set was analyzed in exactly the same manner and it is believed that the consistent methodology provides reliable estimates for the unsaturated zone transport parameters. The results of the curve fitting are shown in Figures 4.1 and 4.2 . The fit of the experimental data to the predicted concentration is very good and indicates that the derived parameters will be valid and suitable for this analysis.

Many of the disposal cribs are situated close to each other and in some cases the measured relative concentrations affect the breakthrough of betaemitting radionuclides from surrounding cribs. (This effect is seen in Figure $\left.4.2^{(b)}\right)$. In these instances the curve fitting procedure was applied only to data points in the first portion of the curve to exclude the influence of breakthrough data of unknown origin.

By this method it is possible to model the effects of hypothetical singleshell tank leaks in the unsaturated zone for the various tank residuals of interest $(100,000,50,000,30,000$ and current inventory gal). Each tank farm area is treated separately because of the different underlying geology between the 200-East and 200-West Areas. The model was supplied with a contaminant pulse iength ( $t$ ime required for waste disposal) determined from each residuai volume, the depth to the water table, the tank farm surface area, a soil porosity of 0.3 (typical of soils in the area), in addition to the parameters determined from the experimental ruthenium-106 fitting. The resulting breakthrough curves were integrated to provide a nondimensional release rate function (i.e., fraction of inventory remaining to flow from the unsaturated zone) for the contaminant transport modeling in the saturated zone. It is assumed that the leakage is controlled by the flow velocity of the soil rather than the leak rate. For the 200-East Area the parameters chosen from the best fit of the ruthenium-106 breakthrough curve data were: 


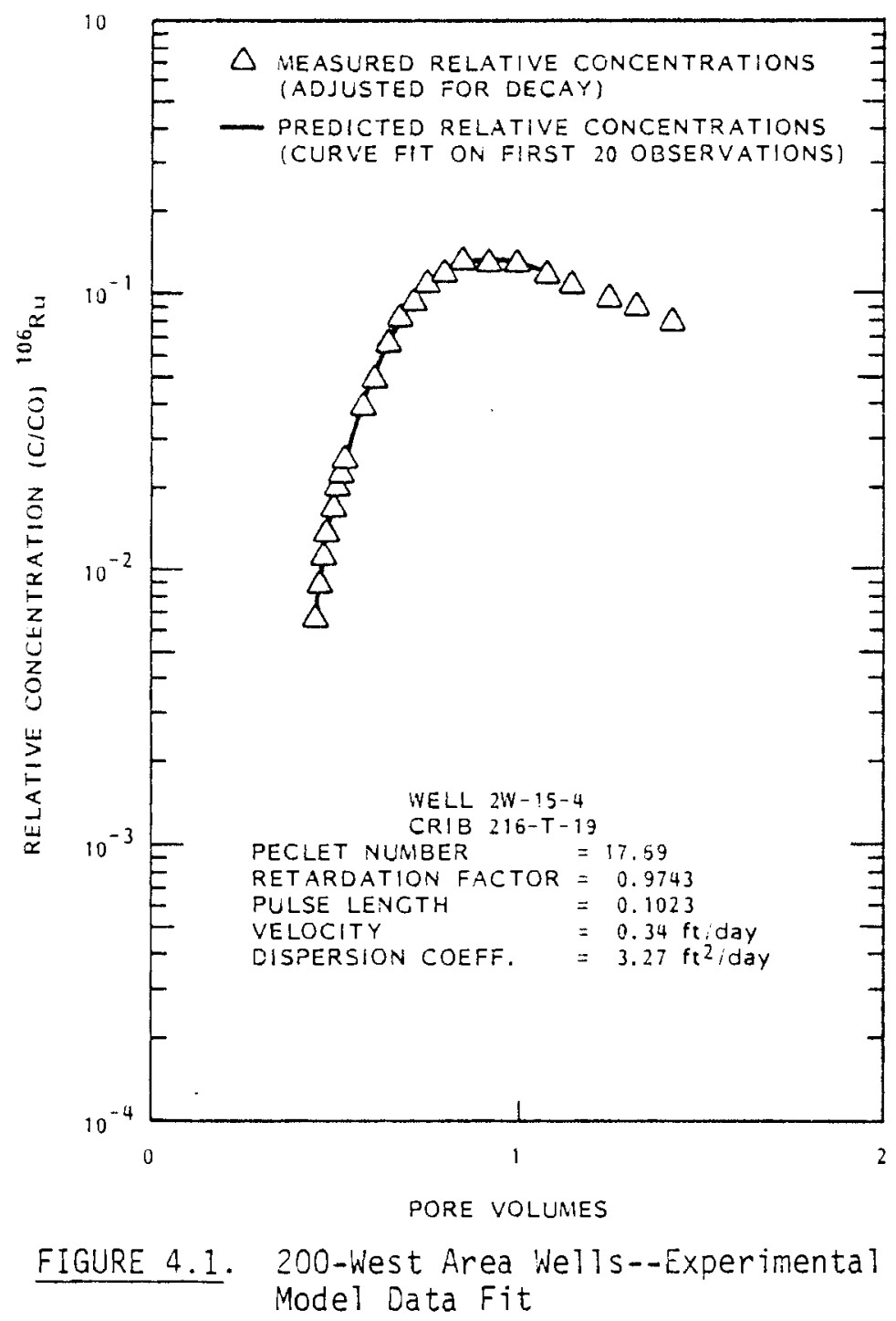

\section{0-East Area}

$\begin{array}{lr}\text { Velocity } & 0.7 \mathrm{ft} / \text { day } \\ \text { Dispersion } & 10.0 \mathrm{ft}^{2} / \text { day } \\ \text { Retardation } & 2.0\end{array}$

For the 200-West Area the parameters were chosen by fitting the ruthenium106 data to wells adjacent to the $S$ and $T$ tank farm areas, respectively. These parameters were: 

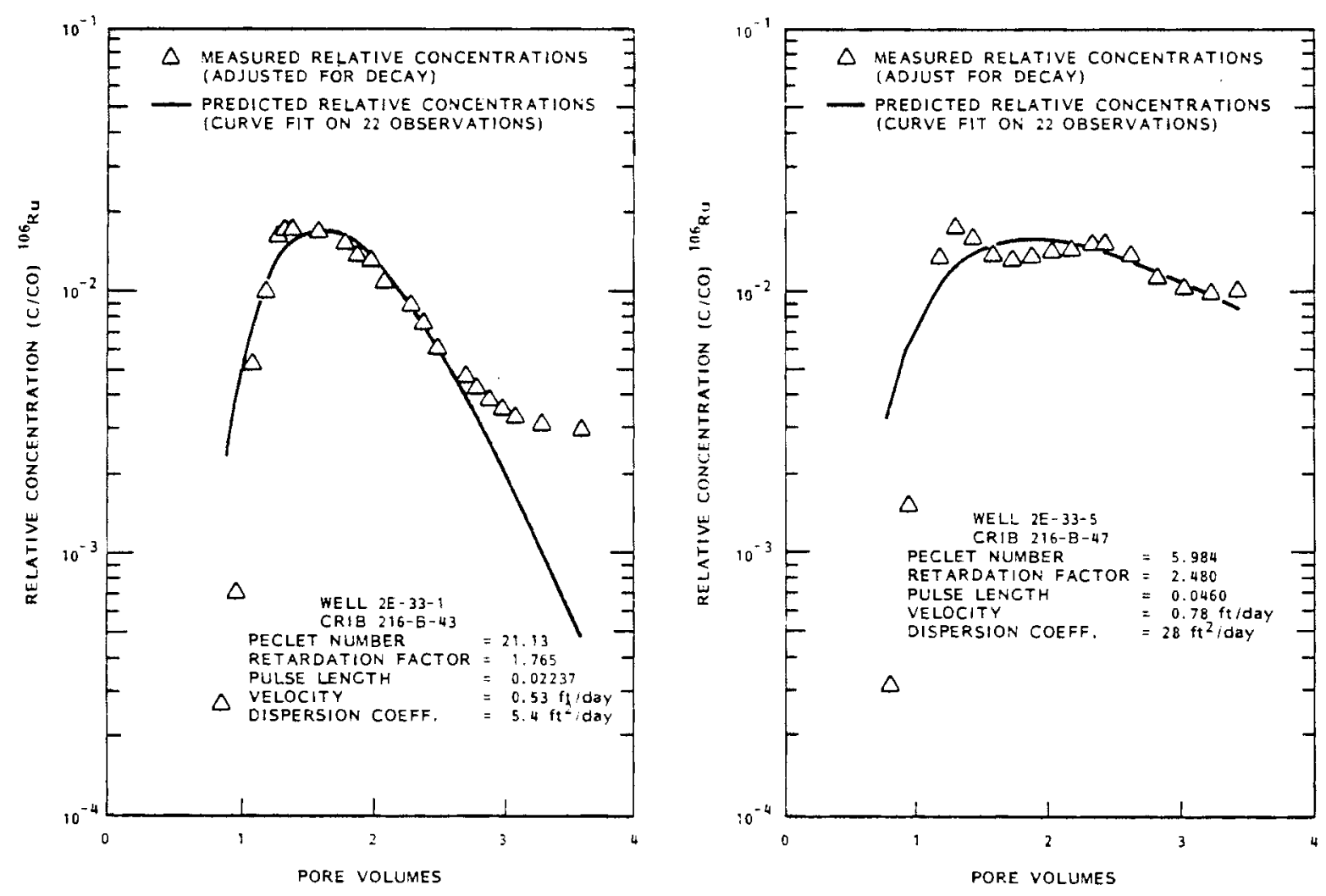

FIGURE 4.2. 200-East Area Wells--Experimental Model Data Fit

\section{0-West Area}

\begin{tabular}{lllll}
\multicolumn{1}{c}{ S- and U-Tank Farm } & & T, TX, and TY Tank Farm \\
Velocity & $0.26 \mathrm{ft} /$ day & & Velocity $0.34 \mathrm{ft} /$ day \\
Dispersion & $0.79 \mathrm{ft}^{2} /$ day & & Dispersion $3.27 \mathrm{ft}^{2} /$ day \\
Retardation & 1.63 & & Retardation 0.974
\end{tabular}

The distance between the various 200-West tank farms and the differences in stratigraphy beneath the farms indicated that better results could be achieved by modeling these farms separately than by averaging the results for the whole 200-West area. This was not necessary for the 200-East Area.

This approach does not take into consideration the volume of liquid that would be retained by capillary forces in the soil above the water table. This is a conservative assumption which results in complete release over time of a 11 the inventory of 1 iquid and radionuclides in the tanks into the ground water. 


\subsubsection{Nonradioactive Components}

Nonradioactive components of the waste tank liquids that could present a health hazard if dispersed in the environment include cadmium, mercury, lead, and nitrates. Cadmium is generally solubility limited to less than $10^{-8}$ molar because it forms precipitates in the presence of carbonates. Carbonates are a major component in the waste tanks and in the Hanford soils. Cadmium also exhibits sorption characteristics similar to strontium and is retarded significantiy in the Hanford soil. Mercury tends to be solubility limited near $10^{-16}$ molar and is also highly sorbed on iron oxides that occur in the Hanford soils. Bacterial action, which could form methyl-mercury is not possible in the tanks or in the soil at depths of any leak. Lead has a solubility limit of $10^{-10}$ molar in the presence of sulfates, carbonates, nitrates, hydroxides, phosphate ions, and also exhibits high retardation in the basic conditions of the Hanford soil. Thus, all of these nonradioactive components of the liquid waste will be retained in the soil in the event of a tank leak and none is expected to reach the ground water.

Nitrates are known to be nonsorbed and will move with the leaked liquid (and ground water) at a rate equal to that of technetium-99. Considering the high concentrations and volumes of drainable liquid and the rates of the assumed leaks, the nitrates will reach the ground water. The nitrate level could reach approximately 3,000 ppm directly beneath a tank farm if all of the nitrates eventually reach the water table. Past data show that dilution, dispersion, and spreading in the ground water will greatly reduce these levels. Although relatively high concentrations of nitrates presently persist beneath cribs which received high salt wastes during the 1950-1960 period, there are only a few wells outside the 200-Area boundaries that show concentrations of nitrate greater than $40 \mathrm{ppm}$ (Eddy and Wilbur 1981). Since none of this water is used for irrigation or human consumption, no danger to public health and safety will result from the nitrate migration to the ground water. The concentrations that would eventually reach the Columbia River from the combination of tank leaks would provide an immeasurable increment to the levels presently occurring. 


\subsubsection{Modeling the Saturated Zone (Ground-Water Aquifer)}

The conceptual Hanford Ground-Water Model (Kipp et al. 1976) utilizes the known geology through a variable hydraulic conductivity distribution developed from pump tests, the aquifer bottom, and the water table elevations (Reisenauer 1979). The computer code, Variable Thickness Transient (VTT) Ground-water Model, is designed to simulate the hydraulic head response (water velocity, watertable height, transit time, etc.) to natural or man-made stress in an aquifer system. The steady-state version of the model was used to simulate 1980 ground-water conditions.

With VTT the stream or flow lines from each tank farm area were modeled and flow tubes characterized through which the saturated ground water would move from the tank farm areas to the Columbia River. Figure 4.3 shows the water table contours and the flow tubes starting from the various tank farm areas. The width and height of flow tubes were selected from the width of the tank farm area perpendicular to the direction of ground-water flow. The height was selected at a nominal mixing depth of $20 \mathrm{ft}$ (Eddy, Myers and Raymond 1978). The results of the flow-tube modeling for each tank farm area are presented in Table 4.1. These flow-tube data were then used as input to the one-dimenional, multicomponent mass transport model, (MMT) (Washburn et al. 1978). A brief technical description of the VTT and MMT models is given in Appendix A.

Nuclides not interacting with the porous media (such as ruthenium-106 are transported with a velocity equal to the average velocity of the ground water along the streamlines defined from the hydrologic model. Nuclides that are absorbed move with a retarded velocity equal to the average velocity multiplied by a retardation factor or "retardation coefficient" $K$, given by:

$$
K=1+\beta \text { Kd (Relyea, Serne and Rai 1980) }
$$

The $\mathrm{Kd}$ is a measure of the ability of a geologic medium (soil) to retard a given nuclide (i.e., the larger the value of $\mathrm{Kd}$, the greater the retention). $B$ is the ratio of bulk porosity or density to the effective porosity. If the bulk density is assumed to be 1.8 for an effective porosity of 0.33 , the value 


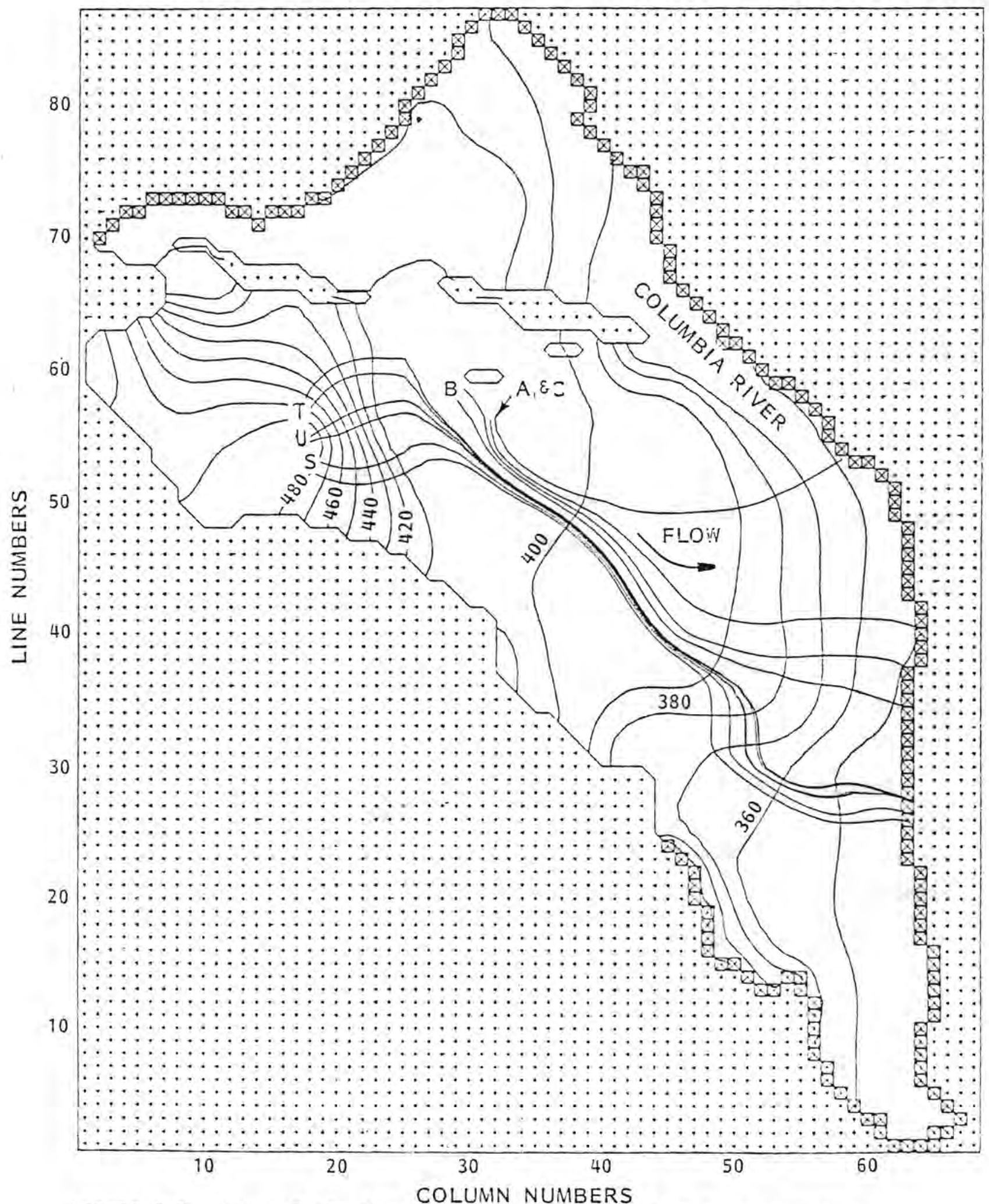

FIGURE 4.3. Water Table Contours and Flow Tubes from Tank Farm Areas to the Columbia River for 1980 Steady-State Conditions 
TABLE 4.1. Input Parameters for the Multicomponent

Mass Transport Model Flow Tubes for Each

of the Modeled Tank Farm Areas

\begin{tabular}{|c|c|c|c|c|c|c|c|c|c|}
\hline Tank Farm & $\begin{array}{c}\text { Average } \\
\text { Travel Time } \\
\text { (yr) }\end{array}$ & $\begin{array}{l}\text { Average } \\
\text { Velocity } \\
\text { (ft/yr) } \\
\end{array}$ & $\begin{array}{c}\text { Average } \\
\text { Path Length } \\
\text { (ft) }\end{array}$ & $\begin{array}{r}\text { Fiux } \\
(\mathrm{ft} 3 / \mathrm{day}) \\
\end{array}$ & $\begin{array}{r}\text { Widrn } \\
(\mathrm{ft})\end{array}$ & $\begin{array}{l}\text { Height } \\
(f \mathrm{t}) \\
\end{array}$ & $\begin{array}{r}\text { Gispersion } \\
\text { Coefficient } \\
\text { (ft) } \\
\end{array}$ & $\begin{array}{l}\text { Release } \\
\text { Length } \\
(\mathrm{ft}) \\
\end{array}$ & $\begin{array}{l}\text { Release } \\
\text { Center } \\
(\mathrm{ft}) \\
\end{array}$ \\
\hline \multicolumn{10}{|l|}{$A, A X, C$} \\
\hline Tude : & 127.3 & 580.7 & 73,866 & 15.8 & 579 & 20 & 586.9 & 720 & 360 \\
\hline Tube 2 & 164.9 & 427.9 & 70,573 & $16 . E$ & $1,174.5$ & 20 & 370.6 & 720 & 360 \\
\hline$B, B X, B Y$ & $54: 4$ & $1,581,6$ & 86,040 & 51,4 & 1,741 & 20 & 234.1 & 1,400 & 700 \\
\hline $5,5 x$ & 88.7 & $1,326.9$ & 117,625 & 31.6 & 1.345 & 20 & 21.8 & 500 & 250 \\
\hline T. TX, TY & 190 & 651,6 & 123,843 & 11,3 & $2,792.6$ & 20 & 110.7 & 600 & 300 \\
\hline$\theta$ & 124.8 & 943.6 & 118,724 & 6.33 & 627.3 & 20 & $5 z .7$ & 500 & 250 \\
\hline
\end{tabular}

of $\beta$ becomes 5.5. Immobilization or retardation is primarily viewed as an adsorption process but can occur by other chemical mechanisms. The water velocity is assumed to be low enough that the ground-water system is in continual equilibrium.

The selection of a single kd value for radionuclides such as strontium-90, cesium-137, and neptunium-237 is difficult, as it is clear that $\mathrm{Kd}$ is highly dependent on the soil types and on the concentrations of other ions in the soil and tank liquid such as sodium, calcium, and potassium.

For this reason, in this study, two sets of Kd values were used to better define the retardation of the various radionuclides of interest in the soil regions directly below the tanks and in the water table. Table 4.2 shows the radionuclides of concern, their half-lives and the $K d$ coefficients chosen.

From these factors it can be shown that the cesium-137 would be sorbed on the soil and retarded well beyond the amount of time it takes to drain the major part of the leaked liquid from the soil above the water table. From the unsaturated zone modeling, the breakthrough of the liquid from the tanks to the groundwater is predicted to be between 0.75 and $2 \mathrm{yr}$ (depending on location). The cesium is predicted to arrive at about 56 times that time or between 42 and $112 \mathrm{yr}$. The drainage of fluid would have long since stopped and the isotopes would be fixed in the soil. 
TABLE 4.2. Radionuclides of Concern, Their Half-Lives

and Kd Coefficients Chosen

\begin{tabular}{|c|c|c|c|}
\hline Radionuclide & Half-Life (yr) & $\begin{array}{l}\text { High Salt (unsaturated } \\
\text { zone) } \mathrm{Kd}(\mathrm{mL} / \mathrm{g}) \\
\end{array}$ & $\begin{array}{l}\text { Diluted (saturated } \\
\text { zone) Kd }(\mathrm{mL} / \mathrm{g}) \\
\end{array}$ \\
\hline $905 r$ & 27.7 & 0.3 & 7 \\
\hline${ }^{99} \mathrm{TC}$ & $2.13 \times 10^{5}$ & 0 & 0 \\
\hline${ }^{129}$ I & $1.57 \times 10^{7}$ & 0 & 0 \\
\hline${ }^{137} \mathrm{Cs}$ & 30 & 10 & 20 \\
\hline${ }^{237} \mathrm{~Np}$ & $2.14 \times 10^{6}$ & 4 & 10 \\
\hline
\end{tabular}

The situation for strontium-90 is slightly more complex and there are several factors which determine that strontium-90 will never reach the river in significant (to the dose modeling) concentrations.

On the basis of the $\mathrm{Kd}$ value ( 0.33 for the unsaturated zone) it can be predicted that the strontium-90 would reach the water table in about two years, which is within the estimated drainage period predicted for the tank 1 iquid. A major factor in the case of strontium-90 is the dilution of the salt concentration as the liquid drains from the linsaturated zone to the water table. It can be shown that the lowest dilution factor expected is approximately 100 for the short period of peak release to the ground water. Much larger factors would be evident at other locations and times away from the peak release rate. This would cause the kd values to rise significantly. From Table 4.1, the shortest travel time beginning when the liquid enters the ground water to the Columbia River is about 54 years. A Kd of 1.5 for strontium-90 would provide a decay time of about 18 half-lives which is sufficient to reduce high levels of strontium-90 to insignificant levels at the river.

Another mechanism also assures that strontium-90 from tank leaks will never be a problem in the river. Hanford tanks contain high solution concentrations of carbonate ion which is stable in the presence of appreciable $\mathrm{Ca}^{+2}$ ion. However, when a tank leak occurs, the high concentration of $\mathrm{Na}^{+}$exchanges with $\mathrm{Ca}^{+2}$ in the soil. The solubility product of calcium carbonate is exceeded 
and the precipitation of $\mathrm{CaCO}_{3}$ does an effective job of scavenging strontium-90 from solution and essentially all of the strontium-90 is retained near the tank (Routson et al. 1979, 1981). Additional evidence that this phenomenon occurs comes from $U$ plant waste disposed primarily at the $B$ cribs in the north end of the 200-East Area and south of the 200-East Area. No significant strontium-90 has been detected in the ground water below these disposal sites (Routson, Barney and Smith 1980; Wilbur and Graham 1982).

The situation for neptunium-237 is not as definitive, although the current consensus is that it is highly improbable that the neptunium-237 (based on considerations similar to those expressed for strontium-90) would ever reach the Columbia River. In view of the long half-life of this radionuclide $(2.14 \mathrm{x}$ $10^{6} \mathrm{yr}$ ), the concern over long-term exposure to the population, as well as a lack of definitive $\mathrm{Kd}$ values; the modeling effort included predictions on the arrival of neptunium-237 at the river based on very conservative assumptions.

The dose consequences presented in Section 5.0 do not include the neptunium237 contribution since it is very probable that significant amount will never reach the river. Information in Appendix $B$ describes the effect of the neptunium-237 assuming that, in spite of all the natural retarding effects, it does eventually arrive at the river. The results indicate that the inclusion of the neptunium-237 produces an insignificant dose (see Section 5.0).

\subsubsection{Results of Modeling Efforts}

Several of the tank farms were grouped and their volumes were added together for modeling because of their proximity to each other. Table 4.3 lists the residual tank volumes for each hypothetical case.

The radionuclides considered were cesium-137, strontium-90, technetium-99, iodine-129, and neptunium-237. The inventory for each was taken from the TRAC computer runs of July 1982. Their residual levels by tank and tank farm group for each case are shown in Table 4.4.

Although the soil layers above the water table will retain approximately an increase of five percent moisture by volume against gravitational drainage, the conservative assumption was made that the total volume of residual liquid was presumed to drain from the unsaturated zone and was transported through the aquifer. 
TABLE 4.3. Residual Volumes by Tank Farm Areas at

Various Termination Levels (in 1,000 gal)

\begin{tabular}{|c|c|c|c|c|}
\hline $\begin{array}{c}\text { Tank Farm } \\
\text { (Single-Shell Only) } \\
\end{array}$ & $\begin{array}{l}\text { Terminate } \\
\text { Pumping } \\
\text { Immediately } \\
\end{array}$ & $\begin{array}{c}\text { Pump to } \\
100,000 \text {-ga }] \\
\text { Limit } \\
\end{array}$ & $\begin{array}{l}\text { Pump to } \\
50,000-g a] \\
\text { Limit } \\
\end{array}$ & $\begin{array}{c}\text { Pump to } \\
\text { Maximum } \\
\text { Liquid Removal } \\
(30,000 \text {-gal Limit) }\end{array}$ \\
\hline$A, A X$, and $C$ & 1,396 & 738 & 571 & 342 \\
\hline$B, B X$, and $B Y$ & 2,682 & 1,751 & 1,159 & 538 \\
\hline$S$ and $S X$ & 2,761 & 1,672 & 926 & 447 \\
\hline$T, T X$, and $T Y$ & 2,581 & 1,620 & 1,053 & 465 \\
\hline U & 1,268 & 819 & 435 & 205 \\
\hline Total & 10,688 & 6,600 & 4,144 & 1,997 \\
\hline
\end{tabular}

Predictions of radionuclide discharge rates $(\mathrm{Ci} / \mathrm{yr}$ ) for each flow tube are produced by the transport simulations. For the purpose of dose calculation, the Columbia River is treated as a single receiving point. The discharge concentration in each flow tube equals the radionuclide flux divided by the groundwater flow rate. Typical discharge concentrations over time at the river for the two radionuclides of primary interest (technetium-99 and iodine-129) are shown in Figures 4.4 and 4.5 , for the "worst case"--where no further jet pumping of the tanks takes place. Similar plots were obtained for all hypothetical cases 100,000-, 50,000-, and 30,000-gal termination residual). In addition, neptunium-237 curves were also obtained to provide the dose calculations given in Appendix $B$. These curves provided the necessary input for the dose caiculations of Section 5.0 .

A1 1 tank farm areas were treated as separate components except for tank farms $A, A X$ and $C$ (Figures 4.4 and 4.5 ). The flow of ground water passing beneath them forms a flow tube which expands greatly before reaching the river, so their volumes and inventory were added together and two flow tubes were run, each with half the inventory. The results were added together on the final graphs to yield, in these cases, a double peak. In all cases the flow tubes output curves are spatially resolved in as much as the release time is short with respect to the travel time of the ground water and distances covered. 
TABLE 4.4. Inventory of Radionuclides of Concern Remaining in Drainable Liquid

Terminate Pumping Immed iate ly

$A, A X$ and $C$

$B, B X, B Y$

$S$ and $S X$

$T$, TX and TY

U

\begin{tabular}{|c|c|c|c|c|}
\hline$\overline{90} \mathrm{Sr}$ & ${ }^{99} \mathrm{TC}$ & $129_{I}$ & $137 \mathrm{Cs}$ & $237 \mathrm{NP}$ \\
\hline $2.1 \times 10^{6}$ & 2,611 & 3.85 & $5.3 \times 10^{6}$ & 0.69 \\
\hline $2.4 \times 10^{3}$ & 6,530 & 10.5 & $1.3 \times 10^{7}$ & 1.45 \\
\hline $9.2 \times 10^{4}$ & 4,700 & 7.5 & $5.9 \times 10^{6}$ & 0.87 \\
\hline $4.9 \times 10^{3}$ & 428 & 6.3 & $5.4 \times 10^{6}$ & 0.91 \\
\hline $1.8 \times 10^{4}$ & 420 & 0.59 & $1.1 \times 10^{6}$ & 0.02 \\
\hline
\end{tabular}

Pump to

100,000-gal Limit
$A, A X$ and $C$
$B, B X$ and $B Y$
$S$ and $S X$
$T, T X$ and $T Y$
$\mathrm{U}$

$8.5 \times 10^{5}$

1,121

1.61

4,030

6.32

$2.2 \times 10^{6}$

0.33

$1.5 \times 10^{3}$

2,800

4.6

$7.5 \times 10^{6}$

0.89

$3.0 \times 10^{3}$

2,580

3.83

$3.7 \times 10^{6}$

0.51

$1.8 \times 10^{4}$

270

0.38

$3.3 \times 10^{6}$

0.55

$7.1 \times 10^{5}$

0.01

Pump to

50,000-gâ] Limit

$\begin{array}{llllll}\text { A, AX and C } & 5.2 \times 10^{5} & 719 & 1.05 & 1.4 \times 10^{6} & 0.22 \\ \text { B, BX and BY } & 9.6 \times 10^{2} & 2,490 & 3.93 & 4.4 \times 10^{6} & 0.56 \\ \text { S and SX } & 3.8 \times 10^{4} & 1,590 & 2.53 & 2.1 \times 10^{6} & 0.29 \\ \text { T, TX and TY } & 1.8 \times 10^{3} & 1,580 & 2.33 & 2.0 \times 10^{6} & 0.34 \\ \text { U } & 9.6 \times 10^{6} & 140 & 0.2 & 3.8 \times 10^{5} & 0.01\end{array}$

Pump to Maximum Liquid Removal (30,000-gal Limit)
$A, A X$ and $C$
$4.1 \times 10^{5}$
532
0.79
$1.0 \times 10^{6}$
0.24
$B, B X$ and $B Y$
$4.5 \times 10^{2}$
1,170
1.84
$2.0 \times 10^{6}$
0.26
$S$ and $S X$
$T, T X$ and $T Y$
$1.6 \times 10^{4}$
760
1.21
$9.8 \times 10^{5}$
0.14
$1.7 \times 10^{2}$
714
$9.5 \times 10^{5}$
$4.5 \times 10^{3}$
68
1.03
$1.8 \times 10^{5}$
0.15
0.10
0.003 


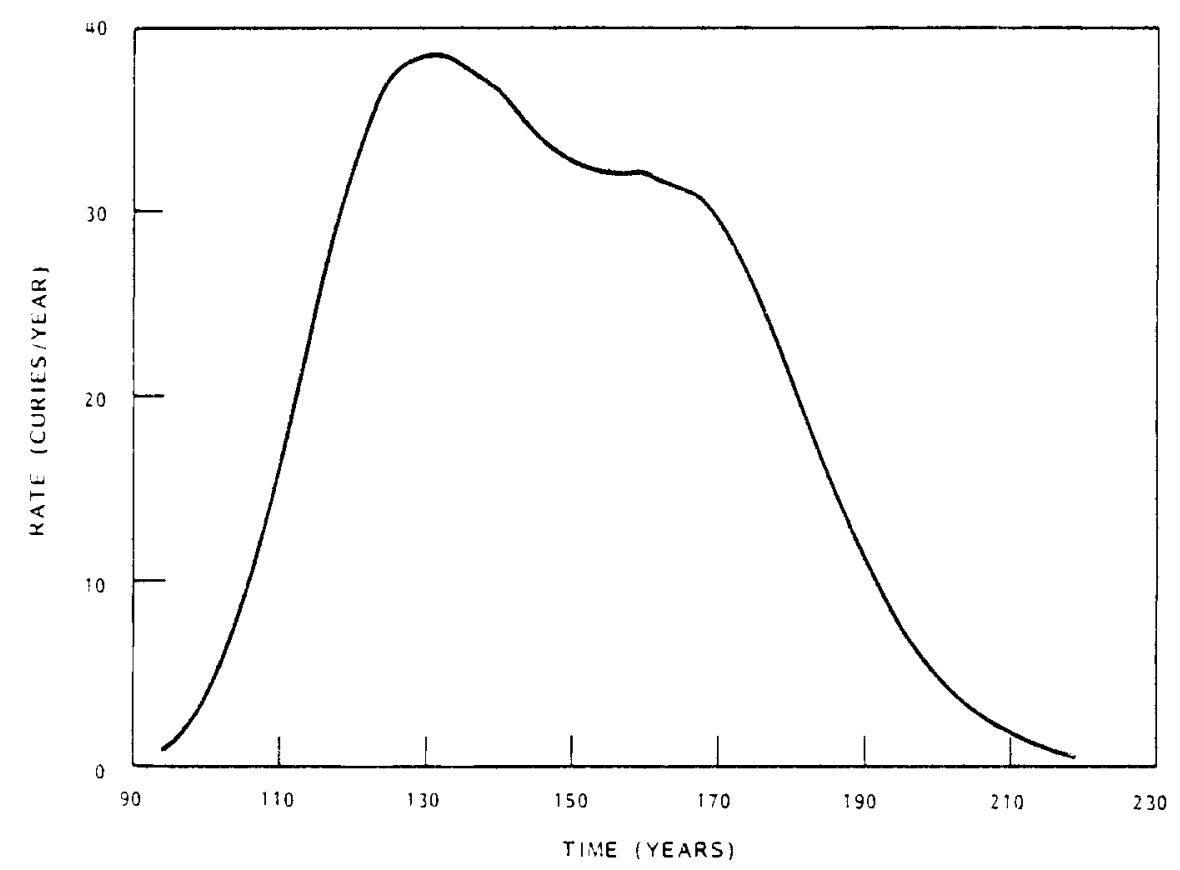

FIGURE 4.4. Discharge of ${ }^{99}$ TC to the Columbia River from $A$ and $C$ Tank Farms

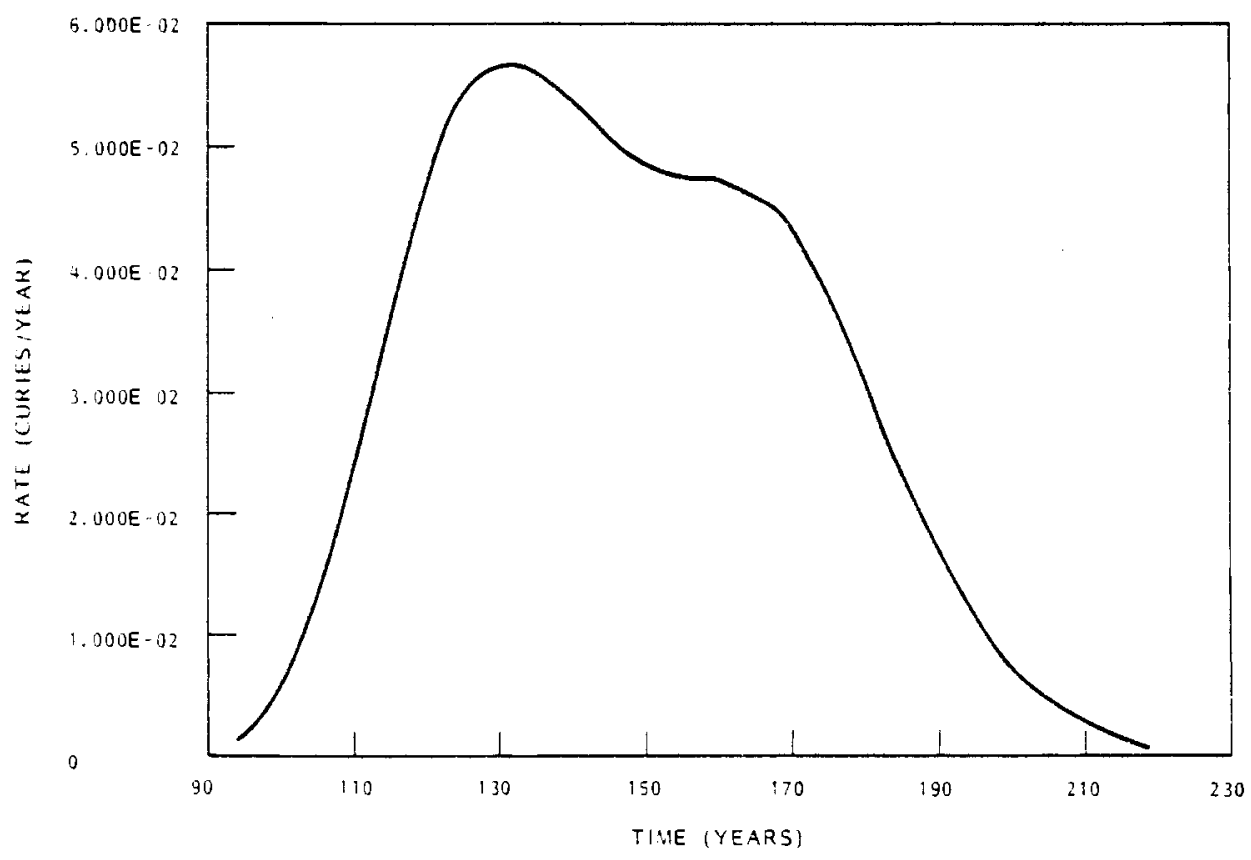

FIGURE 4.5. Discharge of ${ }^{129}$ I to the Columbia River from the $A$ and $C$ Tank Farms 


\subsubsection{Historical Leaks}

Of the 149 single-shell waste storage tanks at Hanford, 26 are presently designated as confirmed leakers, and an additional 31 are of questionable integrity (McCann 1982). Reasons for suspecting tank integrity include: a) anomalies in fluid-level measurement that might indicate leakage but could not be confirmed as such by separate measurements, b) excessive pitting or corrosion of the carbon-steel liner as determined by photographic inspection, c) experience recorded with other tanks of the same age and type of use, and d) detection of radioactivity in one or more drywells with no other verification of a leak. Tanks with confirmed leaks have released around 500,000 gal of stored wastes to the surrounding soil. Nearly half of the total leakage volume was from three of the oldest tanks; 241-U-104 in 1956 (55,000 gal) 241-BX-102 in 1971 (70,000 gal), and 241-T-106 in 1973 (115,000 gal). The leaks from tanks 241-BX-102 and 241-T-106 presently account for about 40 percent of the radionuclides released to the soil. The 241-BX-102 tank is located in the 200-East Area and the 241-T-106 tank is located in the 200-West Area. These major leaks are discussed further in Sections 4.1.2.1 and 4.1.2.2. A number of studies have examined the consequences of radionuclide release from tank leaks (Quinn et a1. 1980; Routson et a1. 1979; NAS 1978; USERDA 1975; ARHCO 1973; Womack and Larkin 1971). A majority of the following discussion is an update of the review by the National Academy of Sciences (NAS 1978).

The minimum volume that can be detected after a tank leak varies with tank design, type of waste stored, and length of tank service:

- for the newer single-shell tanks (AX tanks), special leak collection sumps permit detection of leaks of less than 100 gal

- for those single-shell tanks that have radiation monitoring lateral wells directly beneath them (the A tank farm and some tanks in the $S X$ farm), a leak as small as 5,000 gal can be detected

- for the older tanks, where detection depends on the measurement of liquid levels in the tank and radiation levels in nearby dry wells, the smallest detectable leak ranges from 2,000 to $117,000 \mathrm{gal}$. The variation depends 
on the degree of evaporation of the contents, the amount of fioating salt crust in the tank, and the proximity of the leak to a dry well (Isaacson and Gasper 1981).

Improved detection systems and increased frequency of monitoring established in the wake of the 241-T-106 leak have helped to ensure that in the future large leaks are very unlikely under normal operating conditions.

\subsubsection{241-BX-102 Tank Leak}

Tank 241-BX-102 was confirmed as leaking in 1970 based on an analysis of the liquid-?evel history, dry-well radiation profiles, and soil-sample analysis. The tank leaked approximately 70,000 gal of waste. Nineteen new dry wells and one original monitoring well were used to determine the extent of the contamination. Soil samples were taken at one-foot intervals during the drilling of one of the dry wells. The soil profile under the tank is:

- grade to tank bottom $40 \mathrm{ft}$ - sand and silt backfill

- tank bottom to $70 \mathrm{ft}$ - coarse sand and silt

- 70 to $120 \mathrm{ft}$ - coarse sand and sitt

- 120 to $150 \mathrm{ft}$ - sand

- 150 to $170 \mathrm{ft}$ - coarse sand and si1t

- 170 to $210 \mathrm{ft}$ - sand and gravel

- $210 \mathrm{ft}$ to water table $(260 \mathrm{ft})$ - coarse sand and si1t.

Analysis of scintillation and neutron-probe examinations performed ras resulted in the contamination profile shown in Figure 4.6 (Womack and Larkin 1971). An estimated $31,000 \mathrm{ft}^{3}$ of soil has been contaminated by the waste from the leak. The contamination extends eastward in a 1- to 6-ft wide band for approximately $100 \mathrm{ft}$. It is held for the most part in the upper portions of the sand and silt lens starting $70 \mathrm{ft}$ below grade; however, a small amount percolated to the bottom of this layer $120 \mathrm{ft}$ below grade. During the drilling of one of the monitoring wells, a small amount of contamination was spread to the ground water, but the bulk of the contamination is stable in the sand and silt layer $130 \mathrm{ft}$ above the water table.

The dominant isotope leaked with the waste from Tank 241-BX-102 was about $51,000 \mathrm{Ci}$ of cesium-137. The wetting plume from the leak is no longer moving, 


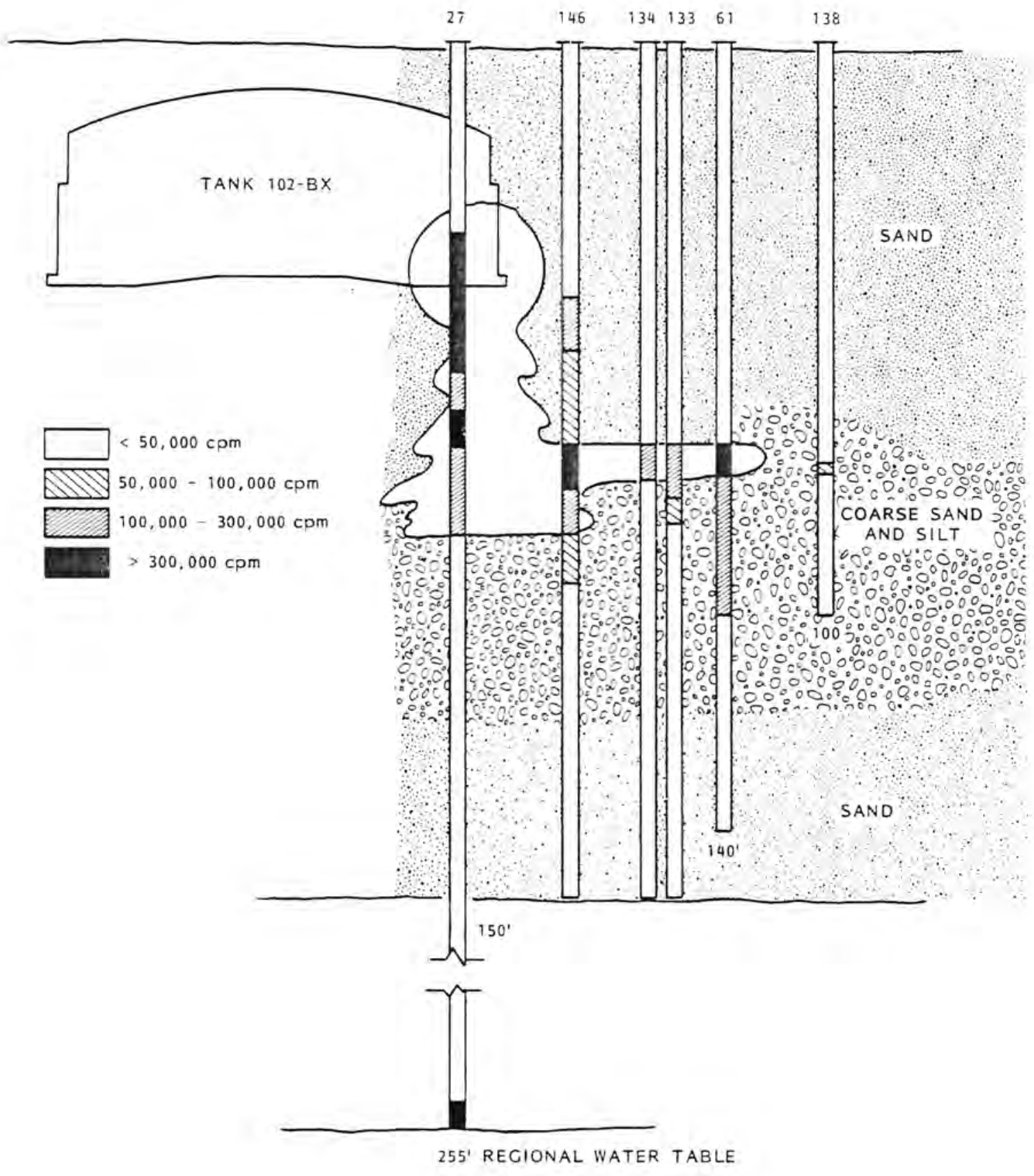

FIGURE 4.6. Subsurface View of Wells with Readings $>50,000 \mathrm{cpm}$ and Estimated Leak Pattern for Tank 241-BX-102 as of January 1971 (Womack and Larkin 1971) 
and the quantity of cesium is gradually being reduced by radioactive decay, from $51,000 \mathrm{Ci}$ in 1970 to around 39,000 $\mathrm{Ci}$ at present. Other than the smal1 amount carried to the ground water during the exploratory drilling phase, no cesium-137 is expected to reach the ground water from this leak. No measurable increase in radiation dose rate has been observed at the ground surface from this leak, and no increase in the contamination level of accessible ground water or surface water has been seen. Thus, the radiological impact of this leak has been insignificant and is expected to remain insignificant.

\subsubsection{241-T-106 Tank Leak}

Tank 241-T-106 was confirmed to be leaking in 1973 following a series of liquid-level measurements. The tank leaked around 115,000 gal to the surrounding soil. Sixteen new dry wells were used to characterize the fate of the escaped waste. The stratigraphy of the sedimentary units beneath the $T$ tank farm is more complex than that in the 200-East Area beneath the BX tank farm described above. There are nine major lithologies (layers) between the water table and the land surface, not including the backfill. These are considered to fall into four groupings; the Hanford, Eolian silt, the Upper Ringold, and the Middle Ringoid formations. Including the backfilled area around the tanks, the soits are:

- surface to $40 \mathrm{ft}$ - cobbles, pebbles, sands, and silt backfill

- 40 to $60 \mathrm{ft}$ - Hanford formation, consisting of completely bedded glaciofluvial deposits of pebbly-to-medium sand

- 60 to $70 \mathrm{ft}$ - fine grained, wind-deposited silts and sands of the Eolian silts

- 70 to $100 \mathrm{ft}$ - well sorted, fine-grained, arkosic sands and silts of the Upper Ringold formation. Two distinct caliche (calcium carbonate) horizons are present near the top of the unit, the lower of which forms a well developed crust with low permeability

- 100 to $200 \mathrm{ft}$ (water table) - cobbles and pebbles in a sand matrix, with numerous sand lenses, the lower portion of which is partially cemented with calcium carbonate. This is the Middle Ringold formation. 
Soon after the leak volumes and radiochemical constituents of the waste Tiquid were determined, it was predicted that the waste liquid would be sorbed onto the dry sediments near the tank and not percolate to the underlying water table. To validate this prediction, a study was conducted to define the boundary of the contaminated zone (ARHCO 1973). The most mobile radionuclide, ruthenium-106, was found to have moved downward from the tank about $50 \mathrm{ft}$ to a depth below grade of about $90 \mathrm{ft}$, and radial1y about $65 \mathrm{ft}$ (Figure 4.7). (It should be noted that the lowermost depth of penetration is approximately the depth of the caliche layer in the Upper Ringold formation). The less mobile nuclides were retained closer than the ruthenium-106 to the tank by sorption on the soil. A reasonable estimate of the maximum extent of the migration of the leaked material is obtained by the $1 \mathrm{\mu Ci} / \mathrm{L}$ isopleth of the ruthenium-106. This isopleth enclosed a volume of about 6.6 million gal in 1973 in an ellipsoid with radii $70 \mathrm{ft}, 90 \mathrm{ft}$, and $30 \mathrm{ft}$. About 70 percent of the activity that leaked into the sediments was retained in a much smaller volume of sediments, in about $83,000 \mathrm{ft}^{3}$ in an ellipsoid with radii $15 \mathrm{ft}, 20 \mathrm{ft}$, and $8 \mathrm{ft}$. These volumes are illustrated in Figures 4.7 and 4.8 . This is an indication of the sorption of most of the radionuclides. A conclusion of the early investigation was that the wastes would show negligible migration from their initial positions.

A follow-on study was performed on the 241-T-106 leak in 1978 (Routson et a 1. 1979). This study used available data obtained from an additional 14 dry wells and the deepening of several others, as well as enhanced instrumentation. Figure 4.8 is a comparison of the boundaries of the contaminated zone in 1973 and 1978. The volume enclosed by the 1978 ruthenium-106 $1 \mathrm{\mu Ci} / \mathrm{L}$ isopleth is only slightly greater than that enclosed by the 1973 isopleth. The figure shows that five years after the leak occurred, the maximum vertical penetration of the liquid was located $110 \mathrm{ft}$ below the ground surface. The maximum horizontal spread was approximately $75 \mathrm{ft}$.

Annual measurements indicated that the movement of the waste occurred mostly in the five-year period between 1973 and 1978. Following that time, the wastes have been quite stable.

The initial leak of $115,000 \mathrm{gal}$ of HLW contained about $270,000 \mathrm{Ci}$ of ruthenium-106, 40,000 Ci of cesium-137, 13,000 Ci of strontium-90, $4 \mathrm{Ci}$ of 

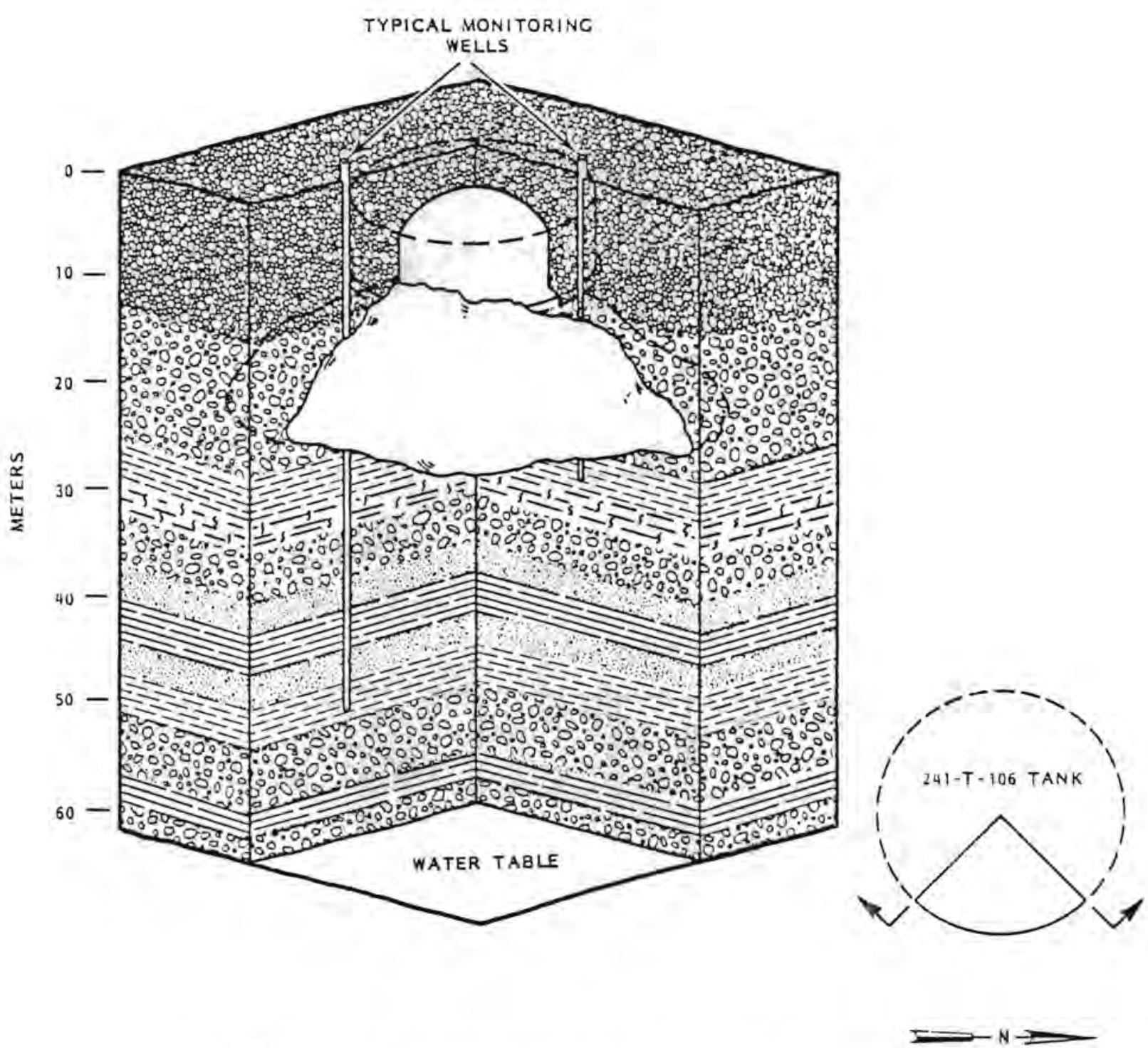

FIGURE 4.7. Three-Dimensional Drawing of Zone of Contamination with Respect to the tank 241-T-106, etc.

plutonium-239 and plutonium-240, and $0.6 \mathrm{Ci}$ of americium-241. Radioactive decay processes have reduced these amounts to around $270 \mathrm{Ci}$ of ruthenium-106, $32,000 \mathrm{Ci}$ of cesium-137, 10,000 Ci of strontium-90, $4 \mathrm{Ci}$ of plutonium, and $0.6 \mathrm{Ci}$ of americium-241. The dry well monitoring data indicate that ail of this activity is retained in the soil near the tank. Additionally, ground-water monitoring is routinely performed in the tank farm area. There is no indication 


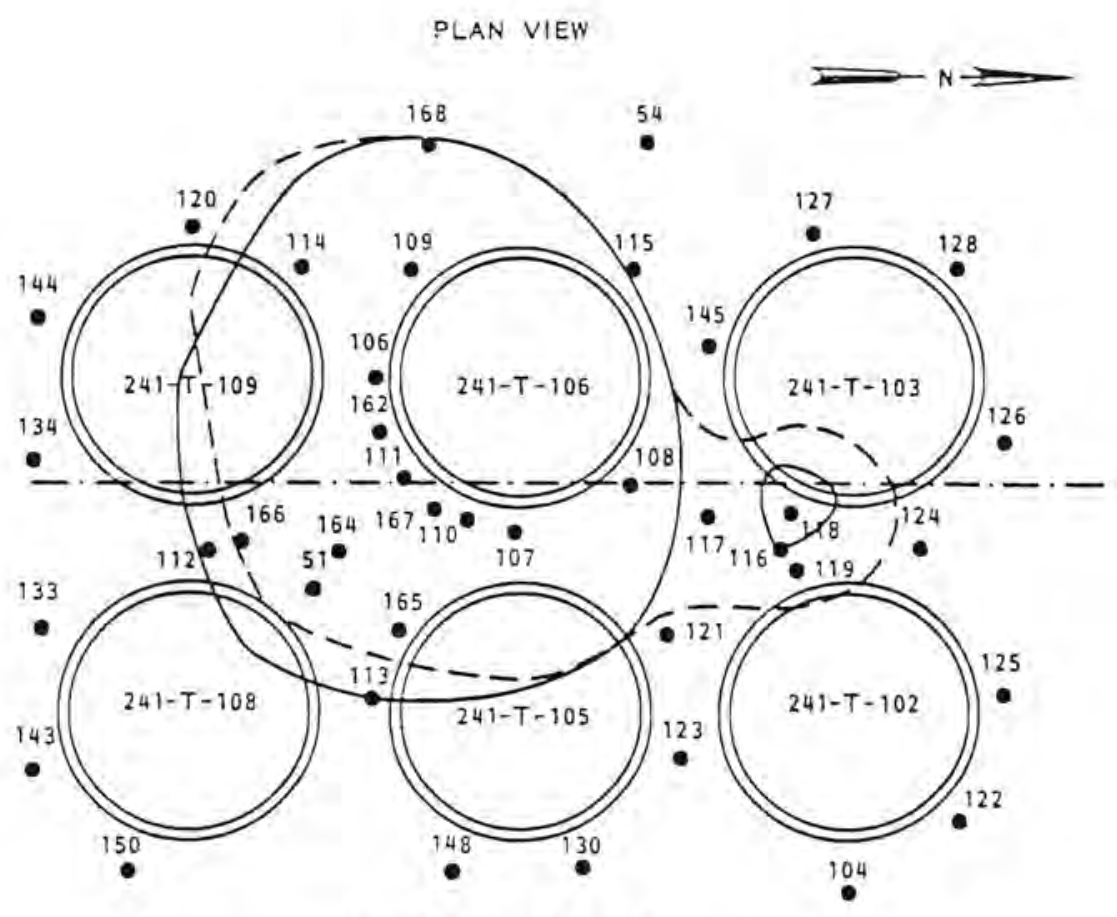

CROSS SECTION VIEW

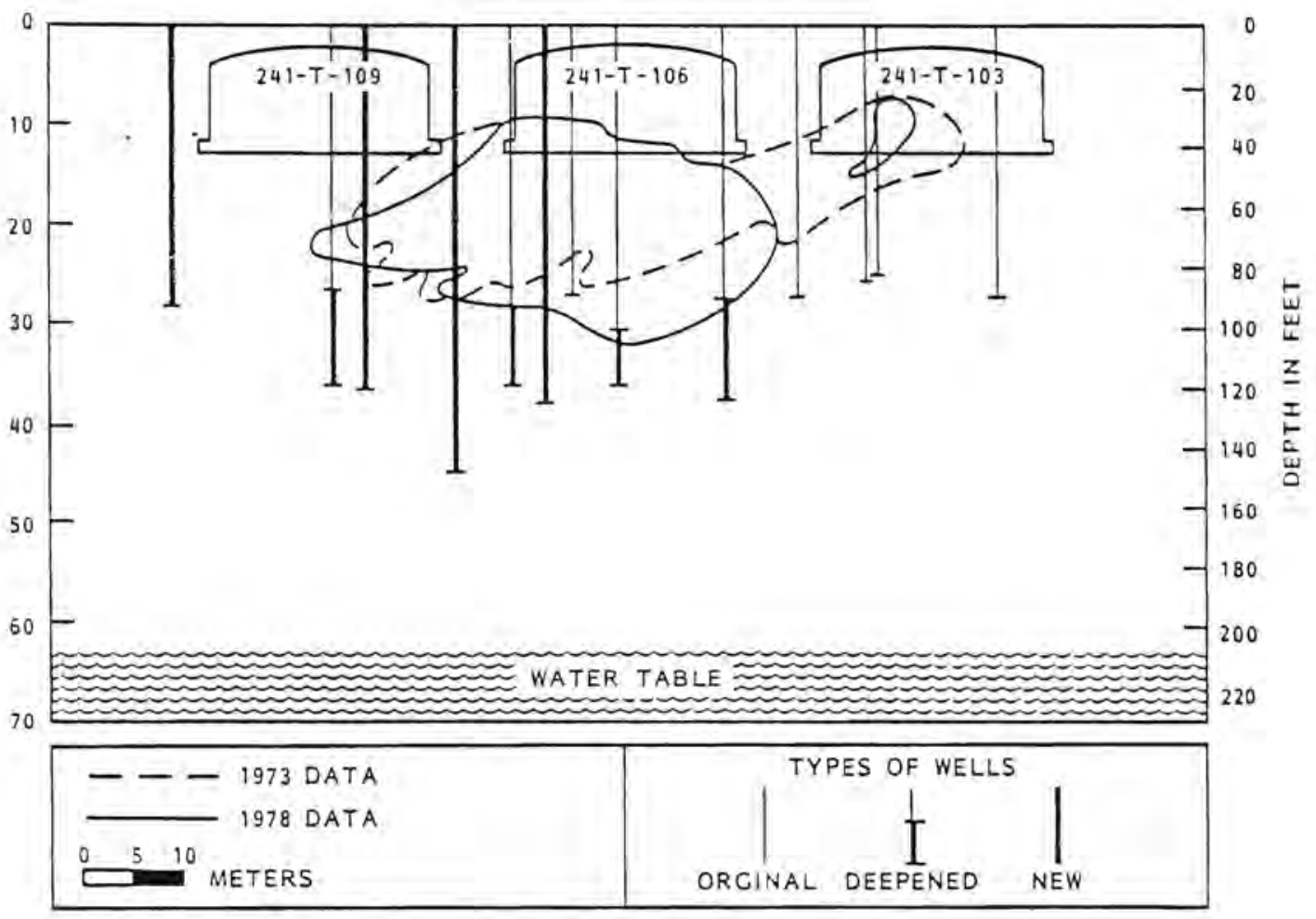

FIGURE 4.8. A Comparison of the Boundaries of the Contaminated Zone from 1973 and 1978 from the 241-T-106 Tank Leak 
of ground-water contamination from these anaiyses. Thus, it seems certain that further movement of the radioactivity from its present location will be negligible.

No migration of the leaked wastes to the surface has been noted. The radiation dose rate in the $T$ tank farm has not been measurably increased by the existence of the leak. Since none of the waste has reached the ground water, and none is likely to, radiation dose to the offsite general public has been and is expected to remain nit. Radiological consequences of the 241-T-106 leak have been and will continue to be minimal (unmeasurable).

\subsection{OTHER RELEASE SCENARIOS}

The potential for tank leaks is the main impetus for pumping the IL from the single-shell tanks. However, changing the condition of the stored waste (increasing the dryness) changes the probability for or potential effect of some other release scenarios as well. One of these is described here.

\subsubsection{Tank Dome Collapse}

No failures of the HLW tank domes have occurred at Hanford or at any other DOE site. Modeling tesis have indicated a margin of safety of four to five times the earth load over the tanks. A life of $100 \mathrm{yr}$ could reasonably be expected based on the life of other reinforced concrete structures (USERDA 1975). However, the dome-failure scenario is one that has received considerable investigation (USERDA 1975, Quinn et a1. 1980, Egger 1981). If the dome on a waste tank were to collapse onto salt cake, particulate salt cake could be released to the atmosphere.

The initial assessment of a dome failure in the Hanford waste management EIS (USERDA 1975) assumed a free space of 100,000 ft inside a tank, and a mass loading of $3 \times 10^{-4} \mathrm{lb} / \mathrm{ft}^{3}$ of soil and sait cake in equal proportion based on aerosol behavior. More recent work by Sehmel on resuspension stresses for vigorous activity in enclosed spaces results in estimates of from 2 to $4 \times 10^{-4} \mathrm{~Tb} / \mathrm{ft}^{3}$ for dry material (Sehmel 1979). Work by Sutter implies that most of the particulates would be generated from the falling dome- and dirtoverburden, not the salt cake (Sutter 1980), so the assumed division of 50 percent 
soil and 50 percent salt cake is probably conservative. However, the assumption that approximately 15 lb of salt cake, as particulates $4 \times 10^{-4}$ in. in diameter or less, might escape still appears to be reasonable and conservative.

The radionuclides contained in 15 lb of salt cake in the year 1985 are estimated and given in Table 4.5. This estimate is developed by decaying the source given in (USERDA 1975), but it compares very closely with an estimate derived from a more recent source (Rockwell 1980). A11 of the referenced analyses of tank collapse have assumed the salt cake to be as free from moisture as possible (IL) as the surface would be at the completion of the present jet-pumping program. The presence of liquids in the tank (surface layer) would act to reduce the emission of particulate salt cake in the event of a dome failure, through liquid surface tension, or viscous effects. The Hanford EIS (USERDA 1975) estimated that the reduction in release could be as much as two orders of magnitude. This is reflected in the second column of Table 4.5.

TABLE 4.5. Radionuclides Released to the Atmosphere by a Catastrophic Tank Dome Collapse(a)

\begin{tabular}{|c|c|c|}
\hline & \multicolumn{2}{|c|}{ Release $(\mathrm{C} i)$} \\
\hline Radionucl ide & Damp Waste & Wet Waste \\
\hline${ }^{3} \mathrm{H}$ & $5.5 \times 10^{-8}$ & $5.5 \times 10^{-10}$ \\
\hline${ }^{90} \mathrm{Sr}$ & $6.7 \times 10^{-4}$ & $6.7 \times 10^{-6}$ \\
\hline${ }^{106} \mathrm{Ru}$ & $1.8 \times 10^{-6}$ & $1.8 \times 10^{-8}$ \\
\hline${ }^{137} \mathrm{Cs}$ & $7.9 \times 10^{-4}$ & $7.9 \times 10^{-6}$ \\
\hline${ }^{144} \mathrm{Ce}$ & $3.7 \times 10^{-7}$ & $3.7 \times 10^{-9}$ \\
\hline${ }^{147} \mathrm{Pm}$ & $1.2 \times 10^{-3}$ & $1.2 \times 10^{-5}$ \\
\hline${ }^{238} \mathrm{Pu}$ & $1.3 \times 10^{-7}$ & $1.3 \times 10^{-9}$ \\
\hline $239_{I}$ & $1.4 \times 10^{-9}$ & $1.4 \times 10^{-11}$ \\
\hline${ }^{239} \mathrm{Pu}$ & $3.3 \times 10^{-7}$ & $3.3 \times 10^{-9}$ \\
\hline${ }^{240} \mathrm{Pu}$ & $1.1 \times 10^{-7}$ & $1.1 \times 10^{-9}$ \\
\hline${ }^{241}{ }_{\mathrm{Pu}}$ & $3.6 \times 10^{-6}$ & $3.6 \times 10^{-8}$ \\
\hline $241_{A m}$ & $8.2 \times 10^{-6}$ & $8.2 \times 10^{-8}$ \\
\hline
\end{tabular}

(a) Adapted from (USERDA 1975) by assuming radioactive decay to 1985 . 


\subsubsection{Other Potential Scenarios}

A number of more "generic" release scenarios were investigated for this study. Many are of a catastrophic nature, such as major floods, meteorite impacts, crashing airplanes, or sabotage (Wallace et a1. 1980; Quinn et al. 1980).

Scenarios of this type do not differentiate between moist salt cake and tanks with residual moisture. None were found to be appropriate for further analysis on the subject of jet pumping. 


\section{.}




\subsection{POTENTIAL IMPACTS OF JET PUMPING}

The present jet-pumping program for removing IL from the single-shell tanks will result in no significant radiation hazard to public health and safety. However, there are some minor sources of atmospheric release that may result in radiation doses to the offsite general public, as well as operating conditions that provide sources of worker exposure. Any reduction in operation of the jet-pumping program would result in reductions for both worker and public radiation exposures. However, reduced pumping would leave greater quantities of liquid in the tanks, with the attendant potential for long-term leakage and possible public exposure to the leaked material. The magnitude of doses that may be received from continued operations will be a function of the quantity pumped, and the potential hazard of future releases will be an attendant function of the quantity allowed to remain.

A comparative summary of the amount of drainable liquids left in the tanks by tank farm at Hanford was shown in Table 3.8. The quantities of liquids pumped for each of the three alternate termination levels investigated in this study are given in this table as are the quantities remaining following cessation of pumping. The table shows that the presently planned program (of pumping to a nominal 30,000-gal termination) could remove over 80 percent of the drainable in-tank liquids. Pumping to a termination value of $50,000 \mathrm{gal}$ would remove over 60 percent, while pumping to a level of 100,000 gal would remove approximately 40 percent of the drainable liquid in all the tanks. Because of their close physical proximity, the tanks are considered to be clustered in groupings of $A, A X$, and $C$ farms; and B, BX, and BY farms in the 200-East Area, and $S$ and SX farm; T, TX, and TY farm; and $U$ farm in the 200-West Area in the following analyses.

Radiation doses for both exposed workers and the general public for the different levels of continued pumping are presented in the following sections. Estimated doses are also given for the releases that might be expected following leakage of the liquids remaining once the pumping program has stopped. 


\subsection{OCCUPATIONAL DOSE}

Since the processes involved in pumping, handling, and storing the liquids pumped from the single-shell tanks require manpower, exposure to radiation fields is unavoidable. The installation, operation, and maintenance of the jet-pumping system and associated piping result in most of the exposure.

The liquids are pumped from the single-shell tanks using a system of transfers and holding tanks to an evaporator, where they are concentrated to doubleshell slurry and stored in double-shell tanks. The operation of the evaporator facility also adds a portion of the worker dose. A summary of the doses resulting from the installation, operation, maintenance, and monitoring of the jetpumping facilities is given in Table 5.1. The average annual individual dose to workers associated with these facilities has been found to be $0.44 \mathrm{rem} / \mathrm{yr}$ for operations in 1981. (a) This is approximately equivalent to the average dose to Hanford radiation workers in general, and is less than 10 percent of federal limits. While recent methods have been developed to reduce pump pit exposure, increasing maintenance of the jet pumps will tend to counteract this; therefore, the average dose rate can reasonably be used to extrapolate to total projected worker exposure. For the present case of pumping to the level of maximum liquid removal (nominally $30,000 \mathrm{gal}$ ), the dose is projected to be about 500 man-rem. A change in the termination level to 100,000 - or 50,000-gal per tank reduces the projected worker dose to 300 and 200 man-rem, respectively. Based on the approximate schedules for pumping completion, the total worker doses accrue at a rate of 40 to $60 \mathrm{man}-\mathrm{rem} / \mathrm{yr}$. For comparative purposes, Table 5.1 also includes an estimate of current dose rates to workers involved in other tank farm activities. Maintenance and operation of the tank farms results in an average worker dose rate of about $0.62 \mathrm{rem} / \mathrm{yr}$ to individuals, or about $80 \mathrm{man}-\mathrm{rem} / \mathrm{yr}$ (USDOE 1980). The jet-pumping program contributes an additional 40 to 70 percent to the overall worker exposure from tank farm operations. A termination level of 100,000- or 50,000-gal would reduce the worker dose from jet-pumping operations by approximately 50 percent. Upon completion of jet pumping, the need for

(a) Internal from J. A. Bates to R. L. Koontz dated August 23, 1982, "Salt Well Program Exposure History", 72320-82-301, Rockwell Hanford Operations, Richland, Washington. 
TABLE 5.1. Summary of Occupational Doses Resulting from Continued Pumping to Various Termination Levels

\begin{tabular}{|c|c|c|c|c|}
\hline $\begin{array}{l}\text { Termination Level } \\
\text { (thousands of gal) } \\
\end{array}$ & $\begin{array}{c}\text { Work-Force } \\
\text { Requirements } \\
\text { (man-yrs) } \\
\end{array}$ & $\begin{array}{l}\frac{\text { Approxima }}{\text { Ind ividua }} \\
\text { (rem/yr) }\end{array}$ & $\begin{array}{l}\text { Dose Rate } \\
\frac{\text { Group }}{\text { (man-rem/yr) }}\end{array}$ & $\begin{array}{l}\text { Totals } \\
\text { (man-rem) }\end{array}$ \\
\hline 100 & 472 & 0.44 & 30 & 200 \\
\hline 50 & 611 & 0.44 & 40 & 300 \\
\hline 30 (Present Case) & 1,125 & 0.44 & 60 & 500 \\
\hline Tank Farm Annuai (a) & -- & 0.62 & 80 & $\cdots$ \\
\hline
\end{tabular}

(a) Taken from USDOE (1980a), Table 5.2, for a total of 130 monitored tank farm workers in 1978.

routine tank farm maintenance would be decreased somewhat, resulting in a slightly lower dose rate at the tank farms. This reduction has not been estimated.

While there have been some spills of HLW on the soil surface during waste management operations (USERDA 1975, Appendix II.1-C), none of the major tank leaks has resulted in increased radiation dose rates at the ground surface (see Section 4.1.2). One study has modeled the potential upward migration of radionuclides from a tank leak (Quinn et ai. 1980). This study made a theoretical analysis of the amount of material that might migrate to the surface in $10 \mathrm{yr}$ following a leak of 30,000 gal of waste. The ratio of curies in the top $3 \mathrm{ft}$ of soil $10 \mathrm{yr}$ after the leak, to total curies available was estimated to be $1.0 \times 10^{-5}$ for strontium-90, $5.5 \times 10^{-6}$ for cesium-137, $7.1 \times 10^{-5}$ for ruthenium-106 (and the equally mobile nuclide technetium), and zero for actinides. Application of these fractions to the material available in an example tank farm (the TX farm is used) results in the contamination levels given in Table 5.2, following a postulated loss of all drainable liquid. Radiation dose rates, calculated using the shieiding code ISOSHLD (Engei, Greenborg and Hendrickson 1966), for these contamination levels are given in Table 5.3. These dose rates, while higher than those that generally prevail in the tank farms away from certain tank facilities, would not result in greatly increased worker doses even if the worker were to spend a great deal of time in the area. 
TABLE 5.2. Potential Tank Farm Surface Soil Contamination Levels Following Leakage of All Drainable Liquids at Various Termination Levels

\begin{tabular}{|c|c|c|c|c|}
\hline \multirow[b]{2}{*}{ Radionuclide } & \multicolumn{4}{|c|}{ Radionuclide Concentrations, $\mathrm{Ci} / \mathrm{m}^{3}$} \\
\hline & $\begin{array}{c}\text { Terminate } \\
\text { Pumping } \\
\text { Immediately }\end{array}$ & 100,000 gal & 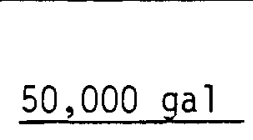 & 30,000 gal \\
\hline${ }^{90} \mathrm{Sr}$ & $1.2 \times 10^{-6}$ & $6.9 \times 10^{-7}$ & $3.9 \times 10^{-7}$ & $1.8 \times 10^{-7}$ \\
\hline${ }^{99} \mathrm{TC}$ & $1.7 \times 10^{-6}$ & $9.8 \times 10^{-7}$ & $5.5 \times 10^{-7}$ & $2.6 \times 10^{-7}$ \\
\hline${ }^{106} \mathrm{Ru}$ & $3.4 \times 10^{-13}$ & $1.0 \times 10^{-13}$ & $1.1 \times 10^{-13}$ & $5.3 \times 10^{-14}$ \\
\hline${ }^{137} \mathrm{Cs}$ & $7.2 \times 10^{-4}$ & $4.2 \times 10^{-4}$ & $2.4 \times 10^{-4}$ & $1.1 \times 10^{-4}$ \\
\hline
\end{tabular}

TABLE 5.3. Potential External Dose Rate from Contamination Levels of Table 5.2

\begin{tabular}{|c|c|}
\hline $\begin{array}{l}\text { Termination Level } \\
\text { (thousands of gal) } \\
\end{array}$ & $\begin{array}{l}\text { Dose Rate } \\
(\text { rem/hr) }\end{array}$ \\
\hline 100 & $9.5 \times 10^{-5}$ \\
\hline 50 & $5.3 \times 10^{-5}$ \\
\hline 30 (Present Case) & $2.4 \times 10^{-5}$ \\
\hline $\begin{array}{l}\text { Terminate Pumping } \\
\text { Immediately }\end{array}$ & $1.6 \times 10^{-}$ \\
\hline
\end{tabular}

Since no upward migration of the wastes has been monitored to date and none is expected, and the analys is by Quinn et al. (1980) is quite conservative, tank leaks should not result in increased radiation fields in the tank farms or increased worker dose.

\subsection{PUBLIC DOSE}

The radiation doses projected for members of the general public from normal jet pumping and waste concentration are calculated using standard Hanford methods (Napier 1981). These are presented in Section 5.2.1. Doses resulting from the potential release scenarios discussed in Chapter 4.0 are developed from the enhanced models described in Appendix $B$. These doses are given in given in Section 5.2.2. 


\subsubsection{Doses from Normal Operations}

In the pumping and handling of the $I L$, the radioactive material is contained in underground single-shell tanks, transfer lines, storage vaults, and associated facilities. There is little chance for release of waste to the environment in these activities. Volume reduction of the wastes occurs in an evaporator-crystallizer facility. This facility is a forced-circulation evaporator that concentrates the IL and produces a slurry with up to 30 volume percent crystalline solids. The evaporated and condensed water from the waste is routed through an ion-exchange column and disposed of in underground cribs. The evaporator is maintained at operating temperatures and pressures of about $140^{\circ} \mathrm{F}$ and 0.8 psia (Petrie et al. 1976). These relatively low temperatures prevent the volatilization of mobile radionuclides. The evaporator has a capacity of 40 to $50 \mathrm{gal} / \mathrm{min}$, which is a rate well in excess of $1,000,000 \mathrm{gal} / \mathrm{mo}$. Since each of the options in this study requires that the jet-pumping program produce 1 iquid wastes at a rate of around $1,000,000 \mathrm{gal} / \mathrm{yr}$, only a small fraction of the capacity of the evaporator is required.

Since most of the condensate is routed to cribs, very little radioactive material escapes from the evaporator to the atmosphere. Operating records show that the evaporator emissions average about $2.0 \times 10^{-6} \mathrm{Ci} / \mathrm{mo}$ of plutonium and around $2.0 \times 10^{-5} \mathrm{Ci} / \mathrm{mo}$ of combined beta emitters (Rockwell 1981). Using the conservative assumption that all of the emissions from the evaporator result from processing wastes from the jet-pumping program (actually only about 8 percent do) radiation doses to the offsite general public can be calculated. These doses are presented in Table 5.4. The doses given in Table 5.4 are very sma11. They are split approximately evenly between contributions from inhalation and ingestion. The doses calculated are a very small fraction of the 0.4 millirem and 4 man-rem calculated for the Hanford maximum individual and general population from normal Hanford operations in 1981 (Sula et al. 1982), and are an even smalier fraction of the dose received from natural sources (background radiation) of 100 millirem to a member of the general public, and 30,000 man-rem to the 50-mi population (population within 50-mi radius of the 200 Areas). Any modifications in the jet-pumping program would produce negligible (undetectable) radiological changes in the environment. 
TABLE 5.4. Radiation Doses to the General Public from Routine Atmospheric Releases During Processing of JetPumped Liquids (242-A evaporator)

\begin{tabular}{|c|c|c|c|c|c|c|c|c|}
\hline \multirow[b]{2}{*}{ Organ } & \multirow{3}{*}{$1-y r$ Dose ${ }^{(a)}$} & $70-y r^{(b)}$ & \multicolumn{3}{|c|}{$\begin{array}{l}\text { Lifetime Dose from Pumping to } \\
\text { Designation Termination }(c)\end{array}$} & \multirow{2}{*}{$\begin{array}{l}\text { Hanford Region } \\
\text { Hanford Operation } \\
\text { Annual Dose }(j) \\
\end{array}$} & \multicolumn{2}{|c|}{$\frac{\text { Background Doses }}{\text { Natural Background (e) }}$} \\
\hline & & Conmitment & 30,000 ga & 50,000 gal & 100,000 oal & & Annual Dose & Lifetime Dose \\
\hline & & \multicolumn{7}{|c|}{ Maximum Individual (rem) } \\
\hline Total Body & $1.6 \times 10^{-9}$ & $7.2 \times 10^{-8}$ & $3.2 \times 10^{-6}$ & $2.4 \times 10^{-6}$ & $1.6 \times 10^{-6}$ & $4.0 \times 10^{-4}$ & $1.0 \times 10^{-1}$ & 7 \\
\hline Bone & $1.3 \times 10^{-8}$ & $1.0 \times 10^{-6}$ & $1.7 \times 10^{-5}$ & $1.3 \times 10^{-5}$ & $8.4 \times 10^{-5}$ & $1.3 \times 10^{-3}$ & $\cdots$ & $\cdots$ \\
\hline Lung & $1.8 \times 10^{-8}$ & $2.3 \times 10^{-8}$ & $1.8 \times 10^{-7}$ & $1.3 \times 10^{-7}$ & $8.9 \times 10^{-8}$ & $2.0 \times 10^{-5}$ & -- & $\cdots$ \\
\hline \multirow[t]{2}{*}{ GI-LLI } & $2.4 \times 10^{-9}$ & $2.4 \times 10^{-9}$ & $2.3 \times 10^{-7}$ & $1.7 \times 10^{-7}$ & $1.2 \times 10^{-7}$ & $5.0 \times 10^{-5}$ & $\cdots$ & $\cdots$ \\
\hline & & \multicolumn{6}{|c|}{ 50-mi Population (man-rem) } & \\
\hline Total Body & $4 \times 10^{-5}$ & $2 \times 10^{-3}$ & $6 \times 10^{-2}$ & $4 \times 10^{-2}$ & $3 \times 10^{-2}$ & 4 & $3.0 \times 10^{4}$ & $2.0 \times 10^{6}$ \\
\hline Bone & $4 \times 10^{-4}$ & $4 \times 10^{-2}$ & $4 \times 10^{-1}$ & $3 \times 10^{-1}$ & $2 \times 10^{-1}$ & 6 & $\cdots$ & $\cdots$ \\
\hline Lung & $7 \times 10^{-4}$ & $9 \times 10^{-4}$ & $7 \times 10^{-3}$ & $6 \times 10^{-3}$ & $4 \times 10^{-3}$ & 3 & $\cdots$ & $\cdots$ \\
\hline$G I-L L i$ & $5 \times 10^{-5}$ & $5 \times 10^{-5}$ & $4 \times 10^{-3}$ & $3 \times 10^{-3}$ & $2 \times 10^{-3}$ & 3 & $\cdots$ & $\cdots$ \\
\hline \multicolumn{9}{|c|}{$\begin{array}{l}\text { (a) The dose during one year from exposure in that year. } \\
\text { (b) The } 70 \text {-year oose commitment from one year of exposure. } \\
\text { (c) The total accumulated dose from continuous exposure from a } 4 \text { - to } 8 \text {-year release and resulting environmentai } \\
\text { contamination. } \\
\text { (d) From Sula et al. (1982). } \\
\text { (e) Contribution from external sources of penetrating radiation only, such as cosmic rays. }\end{array}$} \\
\hline
\end{tabular}

\subsubsection{Doses from Unplanned Releases}

Unplanned releases, as described in Chapter 4.0, can be either abrupt emissions to the atmosphere from collapse of the tank domes or long-term leaks with attendant migration to the environment. The impact of abrupt releases is immediate, and while there may be lingering contamination, most of the human exposure occurs soon after the event. However, for underground tank leaks, radionuclide release to the accessible environment is delayed, and the total impact will not be felt for many years, if ever. Therefore, each type of release is analyzed separately.

\section{Atmospheric Releases}

The only scenario described in Chapter 4.0 having the potential for an acute atmospheric release is the failure of a tank dome. Potential radiation doses to members of the offsite general public from a dome failure are presented in Táble 5.5 for both "damp" waste, which will result if the present $(30,000$ gal per tank) termination value is used, and for "wet" waste, which might result if the pumping were terminated now or at a higher termination value. Doses 
TABLE 5.5. Potential Radiation Doses to the General

Public Resulting from a Tank Dome Collapse

\begin{tabular}{|c|c|c|c|c|c|c|}
\hline \multirow[b]{2}{*}{ Organ } & \multicolumn{3}{|c|}{ Maximum Individual(a) (rem) } & \multicolumn{3}{|c|}{ Population $^{(b)}$ (man-rem) } \\
\hline & $\begin{array}{c}\text { First-yr } \\
\text { Dose }\end{array}$ & $\begin{array}{c}70-y r \\
\text { Commi tment }\end{array}$ & Lifetime & $\begin{array}{c}\text { First-yr } \\
\text { Dose }\end{array}$ & $\begin{array}{c}70-y r \\
\text { Commi tment }\end{array}$ & Lifetime \\
\hline \multicolumn{7}{|l|}{ Damp Wastes } \\
\hline Tota 1 body & $1.9 \times 10^{-2}$ & $2.0 \times 10^{-1}$ & $9.1 \times 10^{-1}$ & $4 \times 10^{1}$ & $4 \times 10^{2}$ & $1 \times 10^{3}$ \\
\hline Bone & $1.5 \times 10^{-1}$ & $2.5 \times 10^{0}$ & $5.1 \times 10^{0}$ & $3 \times 10^{2}$ & $5 \times 10^{3}$ & $8 \times 10^{3}$ \\
\hline Lung & $3.0 \times 10^{-1}$ & $6.3 \times 10^{-1}$ & $6.6 \times 10^{-1}$ & $5 \times 10^{2}$ & $1 \times 10^{3}$ & $1 \times 10^{3}$ \\
\hline Thyroid & $8.0 \times 10^{-4}$ & $8.1 \times 10^{-4}$ & $2.7 \times 10^{-2}$ & $2 \times 10^{0}$ & $2 \times 10^{0}$ & $7 \times 10^{1}$ \\
\hline GI-LLI & $9.0 \times 10^{-3}$ & $9.6 \times 10^{-3}$ & $9.2 \times 10^{-2}$ & $2 \times 10^{1}$ & $2 \times 10^{1}$ & $2 \times 10^{2}$ \\
\hline
\end{tabular}

Wet Wastes

$\begin{array}{llllllll}\text { Total body } & 1.9 \times 10^{-4} & 2.0 \times 10^{-3} & 9.1 \times 10^{-3} & 4 \times 10^{-1} & 4 \times 10^{0} & 1 \times 10^{1} \\ \text { Bone } & 1.5 \times 10^{-3} & 2.5 \times 10^{-2} & 5.1 \times 10^{-2} & 3 \times 10^{0} & 5 \times 10^{1} & 8 \times 10^{1} \\ \text { Lung } & 3.0 \times 10^{-2} & 6.3 \times 10^{-3} & 6.6 \times 10^{-3} & 5 \times 10^{0} & 1 \times 10^{1} & 1 \times 10^{1} \\ \text { Thyroid } & 8.0 \times 10^{-6} & 8.1 \times 10^{-6} & 2.7 \times 10^{-4} & 2 \times 10^{-2} & 2 \times 10^{-2} & 7 \times 10^{-1} \\ \text { GI-LLI } & 9.0 \times 10^{-5} & 9.6 \times 10^{-5} & 9.2 \times 10^{-4} & 2 \times 10^{-1} & 2 \times 10^{-1} & 2 \times 10^{0}\end{array}$

(a) Compare to a background dose rate of $0.1 \mathrm{rem} / \mathrm{yr}$, or about $7 \mathrm{rem}$ for a lifetime.

(b) Compare with a background dose rate of 30,000 man-rem/yr, or a $70-y r$ accumution of 2 million man-rem.

in the first year following the collapse, the dose commitment from the exposure in that year, and the 70-yr lifetime dose that could be received from continued exposure to the material dispersed in the environment are presented. The dose in the early years is due primarily to inhalation of particulate strontium-90 and americium-241. Over the total lifetime, an increase in the dose results from continued exposure to the mobile strontium-90 and strong gamma-producing cesium-137. After a few half-lives following the release, the radiation levels would return to those of essentially the background level preceding the accident. The doses shown in Table 5.5 correspond closely with those estimated in USERDA (1975). There are some differences, primarily the inclusion of ingestion pathways in the result. Newer modeling techniques account for any remaining difference. (The major difference is in the calculation of the atmospheric 
dispersion coefficients to the general public; a more conservative "worst case" is now the standard Hanford method (Napier 1981)).

The dose to the maximum individual following a tank dome collapse would be about three orders of magnitude greater than that received annually from routine Hanford operations. However, it would still be less than the $0.5 \mathrm{rem} / \mathrm{yr}$ DOE standard for the offsite general public.

\section{Ground-Water Releases}

The principal reason for pumping the $I L$ out of the single-shell tanks has been to prevent the occurrence of large leaks to the ground. Historical evidence from past leaks indicates that liquids from individual leaks will not even reach the ground water (see Section 4.1.2). However, the long-term potential is for multiple leaks in each tank farm, so for modeling purposes, all tanks are assumed to leak their contents simultaneously. This is an extreme assumption and is used only to evaluate the consequences of a "worst-case" leak scenario. In reality, the tanks would not all leak simultaneously. If no remedial actions were taken, a few tanks might begin to leak each year, at low rates (the most probable leak rate is only $0.03 \mathrm{gal} / \mathrm{min}$ (Isaacson and Gasper 1981)). It would take many years for the total quantity of liquids to be released to the vadose zone beneath the tanks. The quantity of liquid is then assumed to contaminate the ground water beneath the Hanford 200 Areas. Since it can be shown that about five percent moisture is held up by capillary forces in the soil, and thus will not drain, this is a further conservatism in the calculation. The radionuclides are assumed to reach the water table at a rate distributed in time depending on their sorptive properties and the quantity of liquid available for transporting them. Once in the ground water, they could be carried to the Columbia River in the natural ground-water flow. See Chapter 4.0 (4.1.1) for a more complete discussion of vadose-zone and saturated-zone modeling.

Population doses from slow discharge of radionuclides to the Columbia River have been calculated and integrated for a 10,000-yr period. Doses are given in Table 5.6 for each tank farm grouping, assuming that all drainable liquids remaining for each of the three termination levels escape the tanks. 
TABLE 5.6. Integrated Population Doses Over 10,000 Years (a) Resulting from Leakage of Residual Interstitial Liquids from Tank Farm Groups at Various Pumping Termination Levels

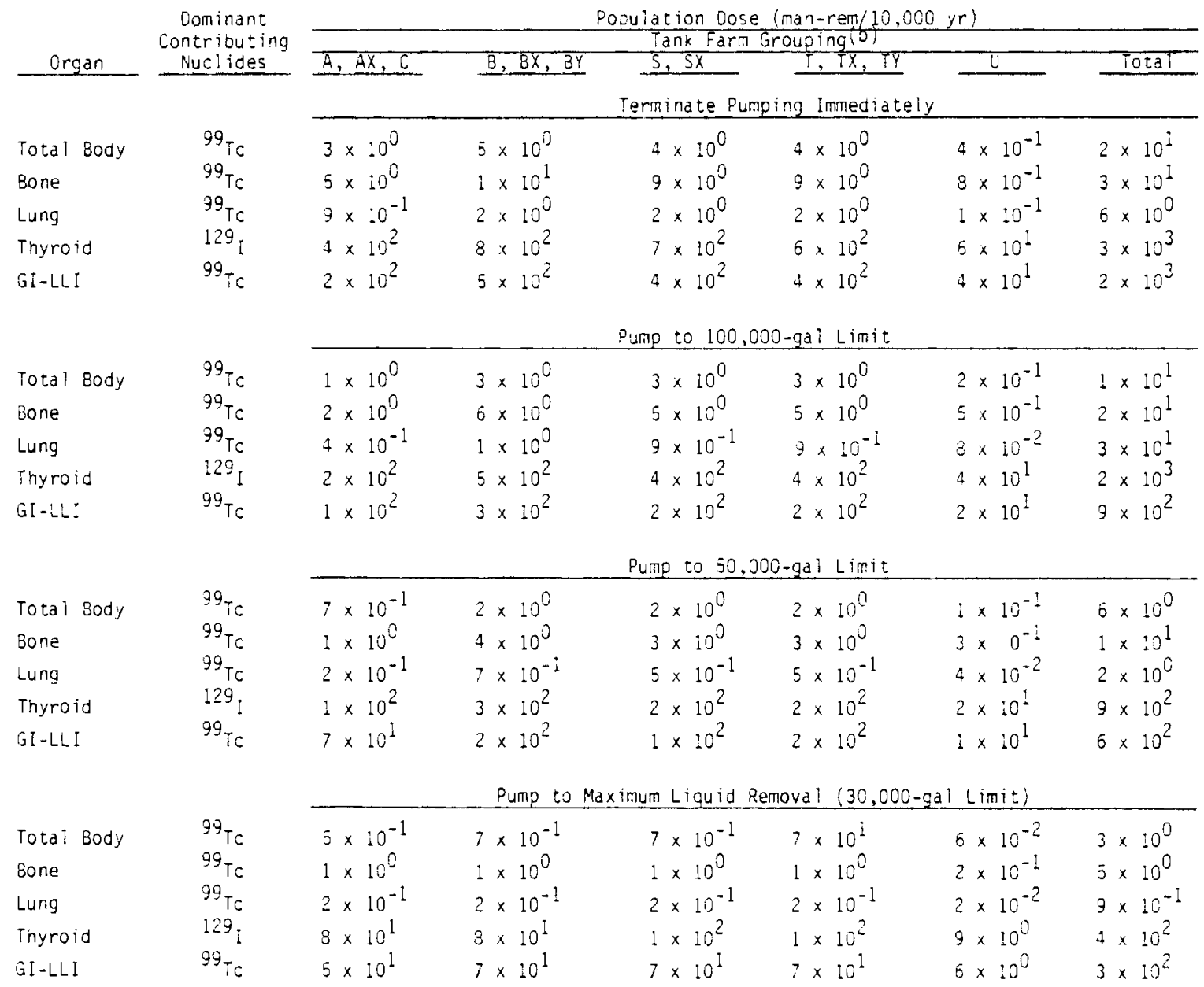

(a) Vatural background radiation doses to the same population would be approximateiy $2.0 \times 10^{9}$ man-rem over the 10,000-year period.

(b) See text.

The total 10,000-yr integrated population dose from leakage of all tank farms is also given. As described in Appendix $B$, these doses include contributions from exposure to contaminated river water, and to materials that might possibly become contaminated by the river water. These include sediments, fish, irrigated crops, soils, and animal products. Exposure pathways include direct exposure through swimming and standing on contaminated beaches and farms, ingestion of contaminated products, and inhalation of resuspended material. 
Calculations of radiation doses to the general public at times far into the future are necessarily inexact. The calculations require predictions of population density and public activities which are, at best, guesses over the time period of concern. Therefore, for the calculations, a large growth in the population is assumed, as is increased use of Columbia River water for drinking and irrigation. These assumptions are used to provide an upper bound of the dose that might be expected. Since there are, by necessity, so many assumptions required, the ultimate population dose for each scenario may vary considerably from those given. However, should there be a bias to the results, it applies equaliy to each of the four pumping termination options discussed. Thus, while the actual results may be greater or less, each predicted result is affected in the same way, and the relative difference in the options is the same. Given the overall magnitude of the predicted results $\left(10^{-6}\right.$ of natural background), the possibility of small errors in the calculation is unimportant.

The rate of dose accumulation is shown for several organs in Figures 5.1 through 5.3. The figures contain results for the $S$ and $S X$ tank farms, for the termination of pumping option. These figures were chosen to illustrate the dependence of organ dose on radionuclide release rate. Very similar curves could be shown for all tank farm groupings for all pumping termination volumes; all have the same basic shape, slightly offset in time or peak magnitude. (These curves also correspond with the examples given in Appendix B). Many factors are immediately evident in these figures. The radionuclides technetium-99 and iodine-129, the only ones considered to be mobile enough to reach the ground water from a tank leak, are calculated to enter the Columbia River in a pulse about 100 to $300 \mathrm{yr}$ following the initiation of the leaks, depending on the distance of each tank farm group from the river. These pulses result in the highest potential dose rates to people living at those future times. However, because these two nuclides are so environmentally mobile, they eventually wash into deeper soil zones, back into the river, or are otherwise removed from the accessible local environment. Therefore, the dose rate to individuals decreases rapidly once the source of radionuclide contamination (the ground water) is again free of contaminants. Figures 5.1 through 5.3 all show this behavior. Figures 5.2 and 5.3 illustrate the organ dependence 


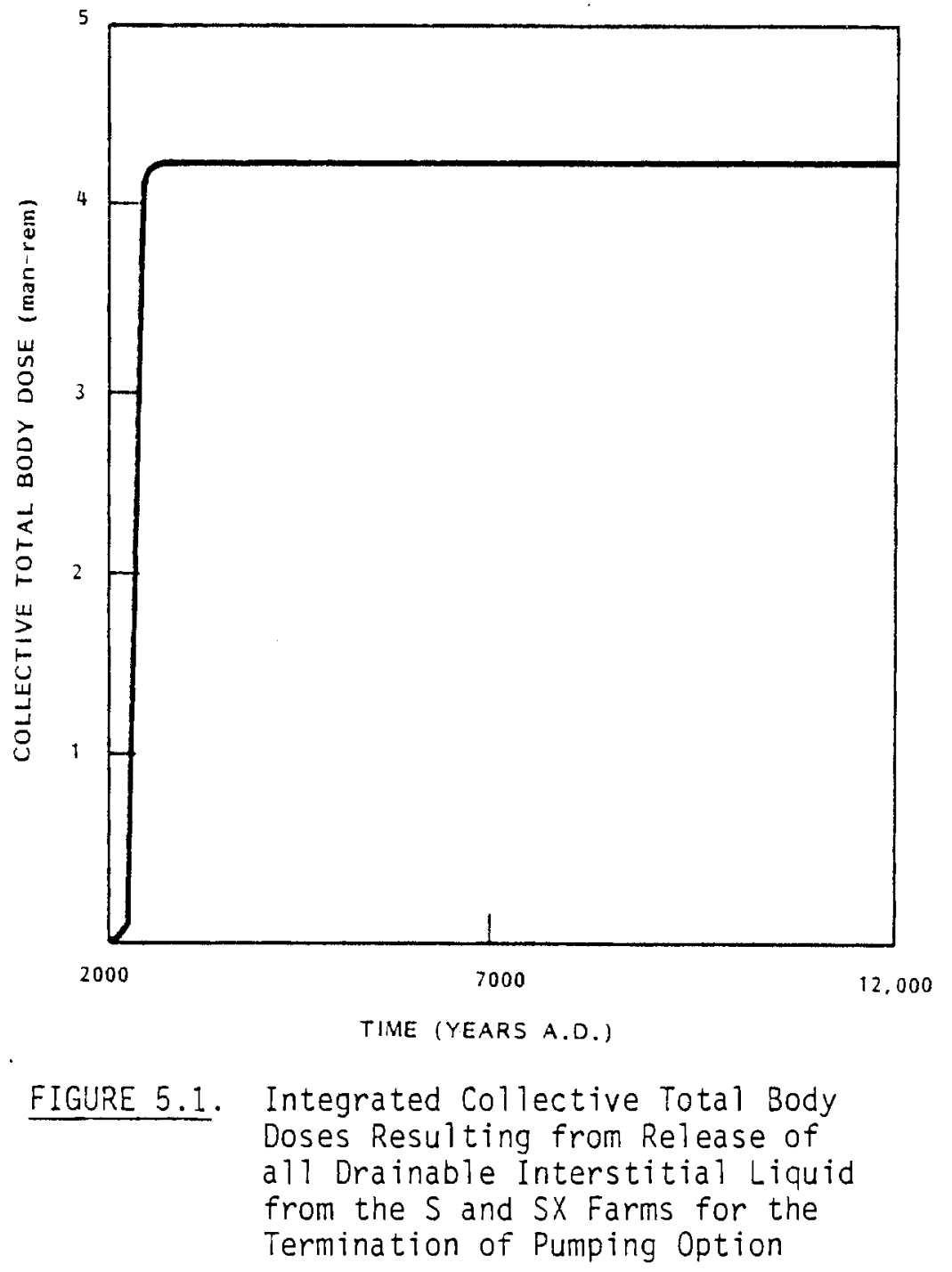

of radionuclides on the calculations. The iodine-129 is preferentially taken up by the thyroid gland, while most of the technetium-9g assumed to be ingested is passed through the GI tract and rapidly eliminated from the body.

Of interest also is the time period at which the dose rate to any individual is the highest. The highest dose rate occurs during the period of highest radionuclide release to the river, during the peaks of the iodine-129 and technetium-99 release, about $150 \mathrm{yr}$ following the assumed tank leaks. Peak 1 ifetime dose rates to individuals are given in Table 5.7. The greatest 


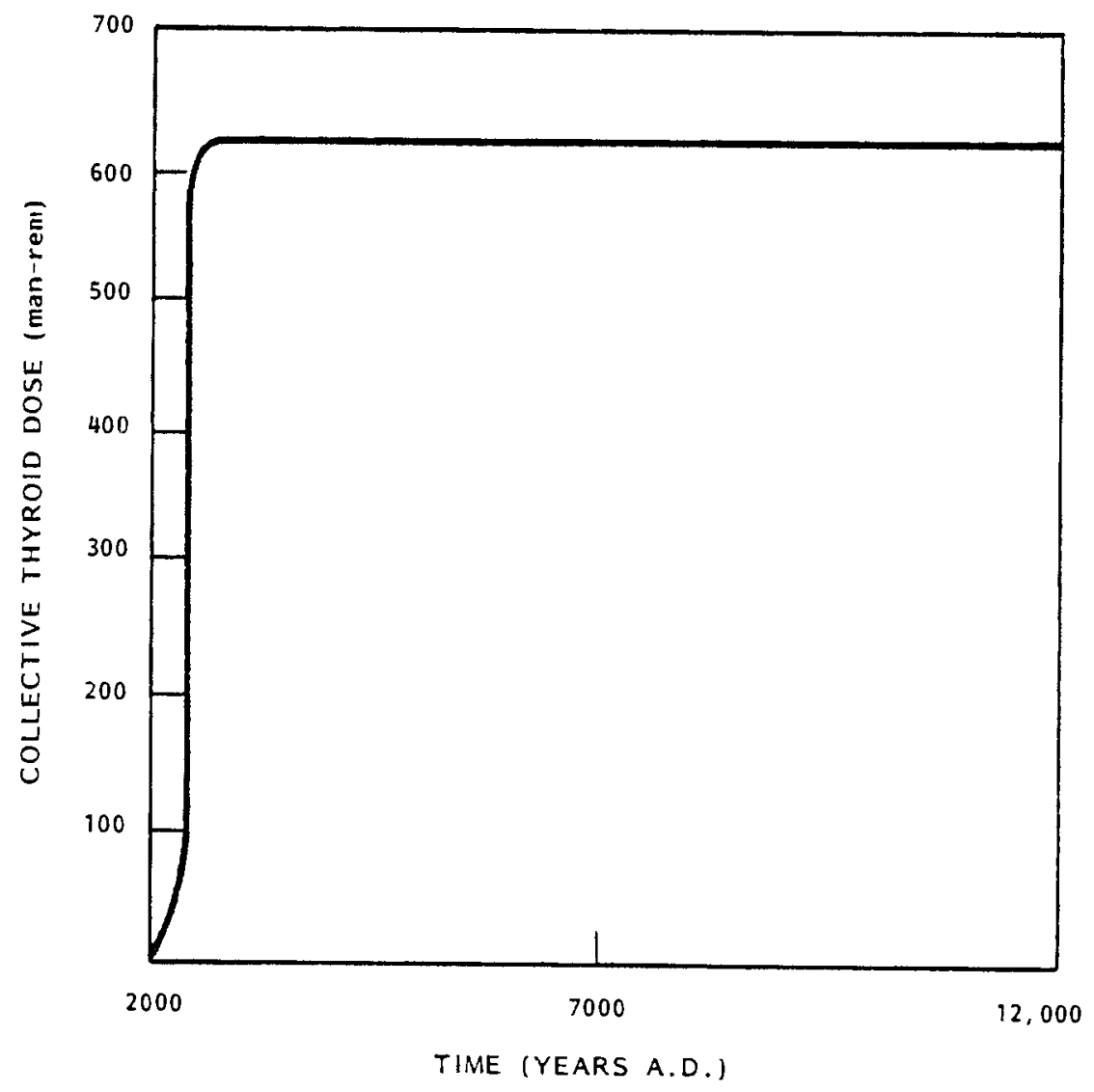

FIGURE 5.2. Integrated Collective Thyroid Doses Resulting from Release of all Drainable Interstitial Liquid from the $S$ and SX Farms for the Termination of Pumping Option

1 ifetime dose to an individual, should pumping cease and all the remaining IL leak, is about $4 \times 10^{-5}$ rem to total body, with a peak organ dose of about $6 \mathrm{mrem} / \mathrm{lifet}$ ime to the thyroid. These doses are negigible compared to the natural dose of about 7 rem/lifetime to an average individual in the Hanford environs.

The discussion above has highlighted the fact that the greatest dose rate from a tank leak could come from the mobile radionuclides technetium-99 and iodine-129 migrating to the Columbia River. It should be noted that radionuclides are presently reaching the river from Hanford operations. These 


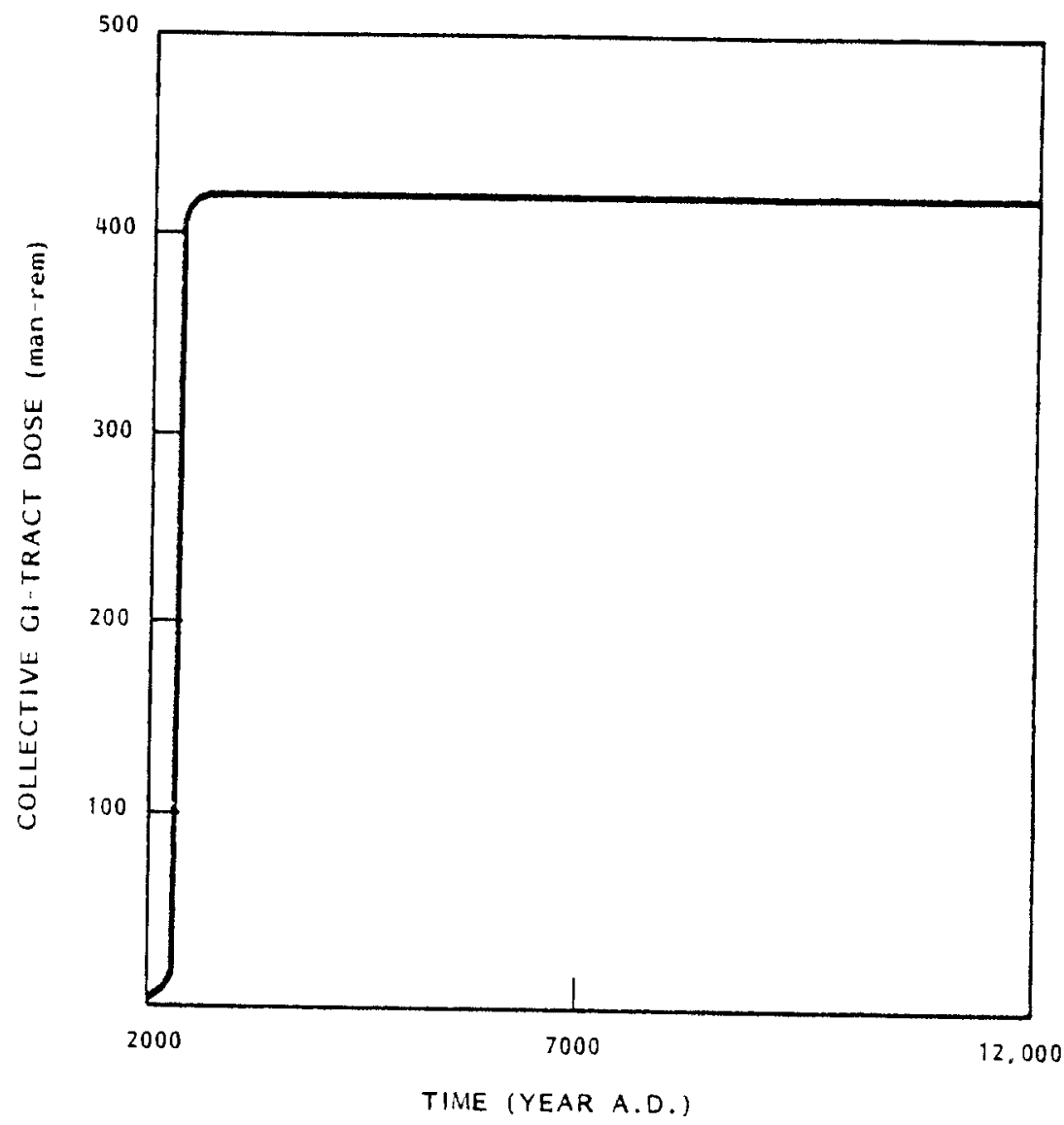

FIGURE 5.3. Integrated Collective GI-LLI Tract Doses Resulting from Release of a 11 Drainable Interstitial Liquids from the $S$ and $S X$ Farms for the Termination of Pumping Option

include tritium, strontium-90, and iodine-129. The report Environmenta? Surveillance of Hanford for CY-1981 Sula et al. 1982) states "The Hanford contribution to iodine-129 in the river is attributed to seepage of ground water from the unconfined aquifer underlying the site into which process cooling water and low-level liquid wastes have been discharged at the 200 Areas. The dose impact due to the net increase in iodine-129 in the river water is negligible." The net increase in Columbia River water concentration due to Hanford operations is measured at $3.9 \times 10^{-5} \mathrm{pCi} / \mathrm{L}$ (Sula et al. 1982; Eddy and Wilbur 1981); the maximum predicted concentration, assuming no further pumping 
TABLE 5.7. Peak Individual Lifetime Doses from Leakage of Interstitial Liquids from Tank Farm Groups at Various Pumping Termination Levels

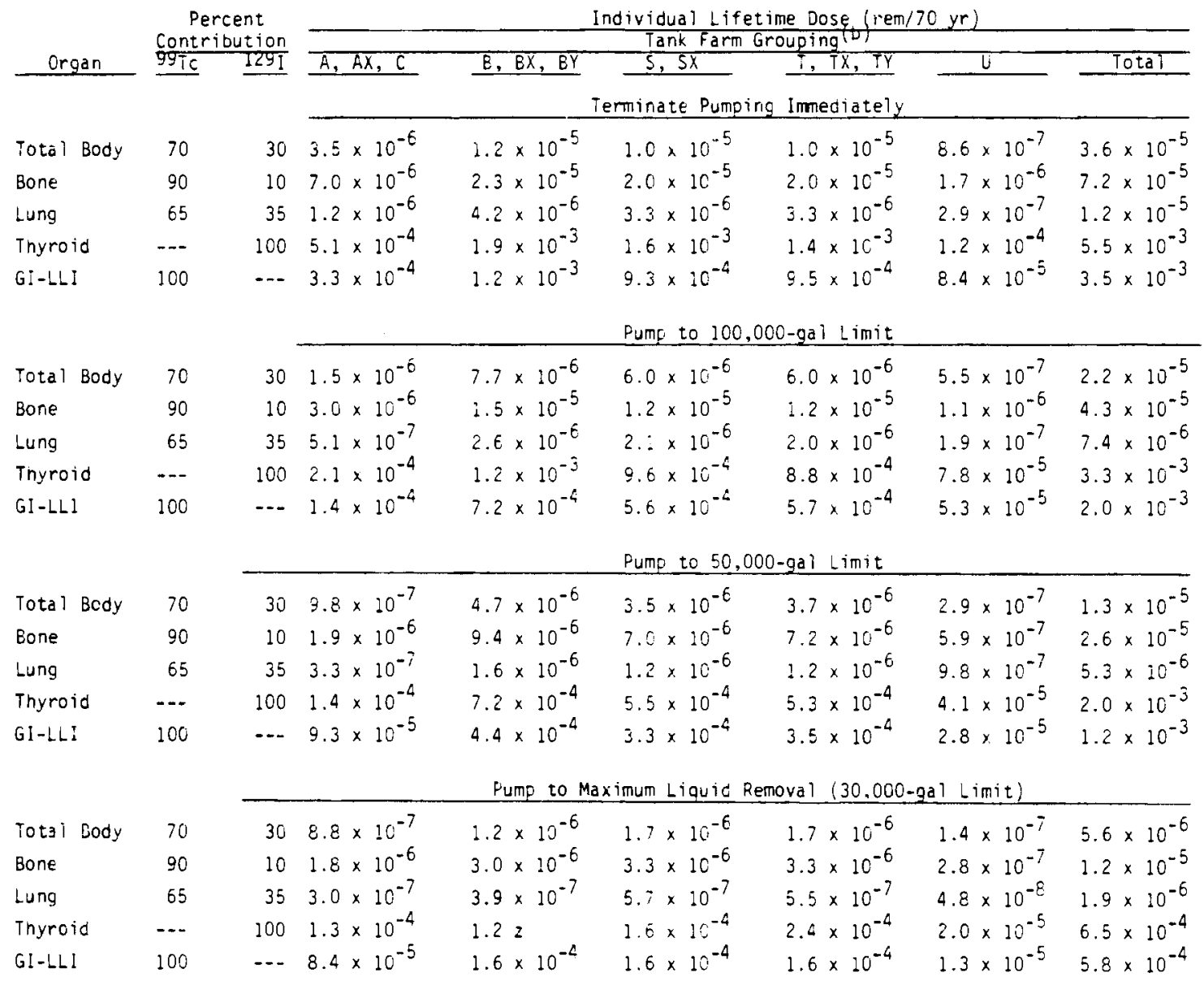

(a) Lifetime dose to the individual would be about 7 rem from natural background sources.

(b) See text.

and leaks of all tanks in all tank farms, is less than $1 \times 10^{-2} \mathrm{pCi} / \mathrm{L}$. For comparison purposes, domestic tap water in the United States averages about $20 \mathrm{pC} i / L$ of all radionuclides from natural sources (ANS 1976). The concentration guides for selected radionuclides in water above natural background for uncontrolled areas (USDOE 1981) allow $300 \mathrm{pCi} / \mathrm{L}$ of technetium-99 and $0.06 \mathrm{pCi} / \mathrm{L}$ of iodine-129. These are much higher than the maximum predicted concentration under even the worst conditions. This illustrates the small impact a total loss of a tank's liquid contents would have. 


\subsection{EVALUATION OF JET-PUMPING OPTIONS}

As stated previously, the major purpose of the jet-pumping program is to reduce the amount of high-level liquid waste that could potentially enter the environment through a single-shell tank leak. The costs and benefits of jet pumping to various termination levels are presented in this chapter in terms of the radiological consequences of pumping, potential consequences of unplanned releases, effect on future waste disposal methods, and expenditure. This information is summarized in Table 6.1.

\subsection{RADIOLOGICAL CONSEQUENCES OF JET-PUMPING OPERATIONS}

The dose to the general public from jet-pumping operations is negligible for all options. The lifetime doses to the maximum individual and population shown in Table 6.1 are approximately an order of magnitude lower than the annual dose from all Hanford operations. The annual dose to the maximum individual of $3.5 \times 10^{-5} \mathrm{mrem} / \mathrm{yr}$ is insignificant compared to the annual dose from background radiation of $100 \mathrm{mrem} / \mathrm{yr}$. The worker dose rate, $0.44 \mathrm{mrem} / \mathrm{yr}$, results in the total doses indicated in Table 6.1. While these doses do increase as more and more liquid is removed from the tanks, they are still less than the allowable dose as set forth in federal guidelines. An evaluation of the radiological consequences of normal jet-pumping operations indicates that they would be well below acceptable limits for all termination levels.

\subsection{POTENTIAL CONSEQUENCES OF UNPLANNED RELEASES}

Scenarios for the unplanned release of waste from single-shell tanks were analyzed, including tank dome collapse and leakage of liquid waste.

As stated in Chapter 5.0 (Section 5.2 .2 and Table 5.6), the dose to the maximum offsite individual following a tank dome collapse would be about three orders of magnitude greater than that received annually from routine Hanford operations. However, it would still be less than the $0.5 \mathrm{rem} / \mathrm{yr}$ DOE standard for members of the general public. This would be true for all jetpumping options, including termination of jet pumping. 
TABLE 6.1. Summary of Benefits and Costs of Jet-Pumping Options

(All doses are potential estimated doses)

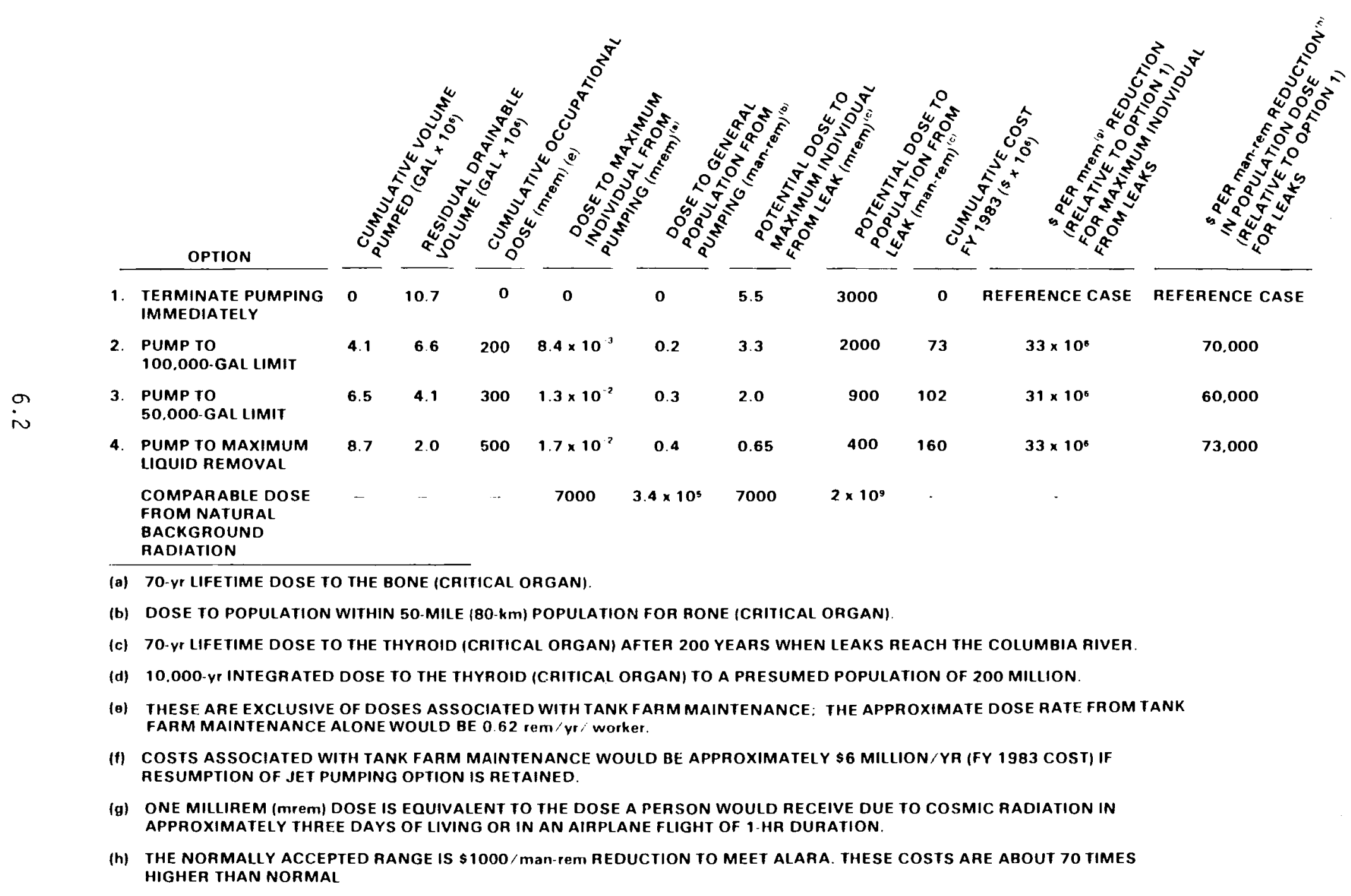


The doses to the critical organ (thyroid) for the maximum individual and general population from leakage of residual liquid from single-shell tanks are listed in Table 6.1 for each jet-pumping option. As indicated by the data in Table 6.1, the dose (thyroid) to the maximum individual and general population from the leakage of all drainable liquid currently in the tanks ( 8.6 million gal) would be $5.5 \times 10^{-3} \mathrm{rem} / 70 \mathrm{yr}$ and $3 \times 10^{3} \mathrm{man}-\mathrm{rem} / 10,000 \mathrm{yr}$, respectively. While this potential dose from leakage would be lowered by pumping the liquid from the tanks, it is already negligible when compared to the natural background dose of about $7 \mathrm{rem} / 70 \mathrm{yr}$ to an average individual in the Hanford environs.

\subsection{EFFECT ON FUTURE WASTE DISPOSAL METHODS}

No in-situ disposal methods would be precluded by adoption of any of the jet-pumping options. However, because the in-situ disposal methods evaluated (see Section 3.3) are in the experimental/demonstration stage, the benefits of continued-versus-restricted liquid removal by jet pumping cannot be determined at this time.

Similarly, no geologic disposal methods would be precluded by the jetpumping options, but the advisability of removing all the liquid possible or allowing some to remain in the tanks would depend on the method used.

\subsection{EFFECT ON EXPENDITURES}

The cost of each jet-pumping option is indicated in Table 6.1. Termination of jet pumping is estimated to cost $\$ 1$ million in program shutdown costs. The cost of continued jet pumping increases from $\$ 73 \mathrm{million}$ to $\$ 160 \mathrm{milition}$ as the allowable residual liquid volume left in the tanks decreases. After the completion of all jet-pumping options, tank farm maintenance along with monitoring and surveillance would still be required until such time as final disposal of the waste has been implemented.

The costs versus the benefits at each level of jet pumping can more clearly be seen through a comparison on an incremental basis. For example, pumping to a 100,000-gal termination level has certain costs and removes a specific volume of liquid from the tanks. Pumping to a 50,000-gal termination level will result 
in the removal of adcitional liquid and will have costs associated with it that are in addition to the expenditures already made to reach the 100,000-gal level. Similarly, continued pumping to the nominal 30,000-gal termination level would have additional costs over and above those already incurred to reach the 50,000-gal level. This is illustrated in Figure 6.1.

\subsection{COMPARISON OF BENEFITS AND COSTS}

The benefits and costs of each termination level, both in terms of expenditures and dose, are shown in Figure 6.1 on an incremental basis and as a percentage of the total. The unit cost for reduction of public dose and liquid volume removed is presented in Table 6.2 for each increment between the jetpumping options. Evaluation of this data indicates that decreasing from a 100,000 -gal to 50,000-gal termination level results in decreased costs for that increment, while a further decrease from 50,000 gal to the pumping 1 imit results in a marked increase in costs for that increment. Two major factors contribute to these results: 1) the increment between 100,000 and 50,000 gal does not add many more tanks so that a saving is achieved simply by continuing to operate those pumps already in place, and 2) the increment between 50,000 gal and the pumping limit has reached the flatter portion of the pumping curve (Figure 3.3) where the rate of liquid removal is very low. At this low rate of liquid removal, the benefit obtained (i.e., a decreased potential dose from leakage) is minimal compared to the cost of an increased worker dose and an increased rate of expenditure. This is especially apparent because the potential dose from leakage is orders of magnitude lower than background (Section 6.2). 


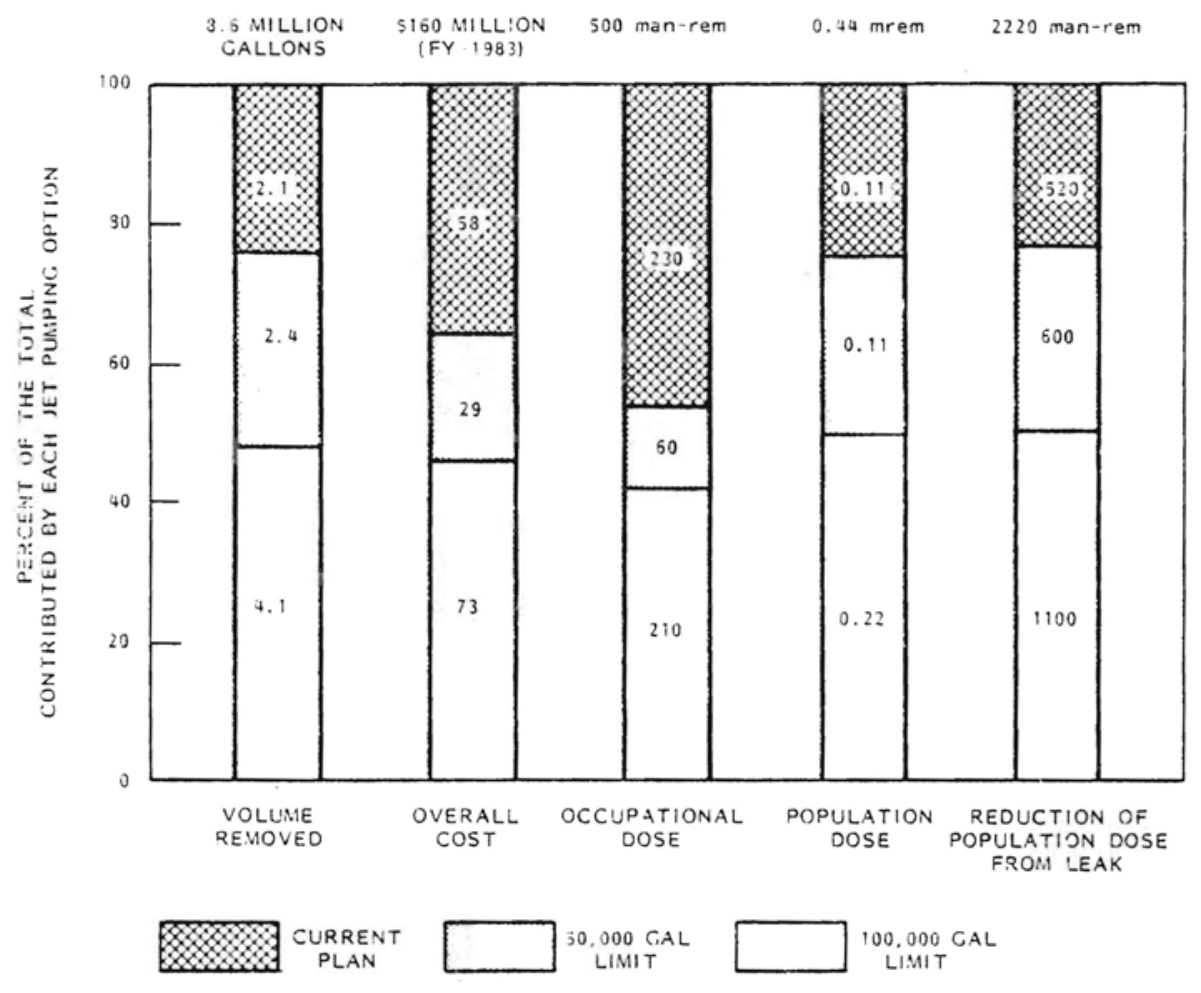

FIGURE 6.1. Incremental Costs, Doses, and Volumes for Each Jet-Pumping Option

\section{TABLE 6.2. Unit Costs of Each Incremental Level} of Interstitial Liquid Removed

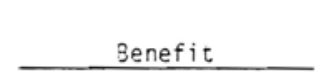

Cost ser additional

gallon removed

Dose per additional

million gallons

removed

Cost and dose to

reduce public dose(b)

by one man-rem

Cost to reduce dose ${ }^{(b)}$

to maximum individual

by one mrem.
Remove an Initial(a)

Volume of 4.1 Million gal (100,000-gal case)

$\$ 20$

50 man-rem worker 0.05 man-rem population

0.2 man-rem worker $\$ 70,000$

$\$ 30$ million
Remove an Additional

2.5 Million gal

(50,000-gal Case)

$\$ 10$

Remove an Additiona 1 2.1 Milition gal (current plan)

$\$ 30$

100 man-rem worker 0.05 man-rem population

20 man-rem worker
0.04 man-rem population

0.4 man-rem worker

0.1 man-rem worker $\$ 50,000$ $\$ 110,000$

$\$ 40$ million

(a) This increment is calculated relative to the option to terminate pumping.

(b) This dose is the potential future dose caused by tank leakage. 


\subsection{CONCLUSIONS}

In the preceding chapters the radiation doses, dollar costs and influence on in-situ disposal were presented for four jet-pumping options for the singleshell tanks:

- terminating pumping immediately

- jet pumping to a 100,000-ga 1 limit of IL

- jet pumping to a 50,000-gal limit of IL

- pumping to maximum liquid removal (30,000-gal 1imit) i.e., pump until a pumping rate of $0.05 \mathrm{gpm}$ is reached.

Significant conclusions of this report are:

1. Based on environmental health and safety results presented earlier, jet pumping is not a technically and economically practicable method of reducing undue risks to the safety and health of the public and workers.

2. Continued jet pumping or its immediate termination would not perceptibly increase or aiter the protection of public health and safety since doses from potential leaks would be insignificant $(0.0001$ percent of doses from natural background radiation).

3. Jet-pumping operations contribute small amounts to worker and public doses.

4. Jet pumping does not eliminate the fotential for leaks from single-shell tanks, although it reduces the size of a potential leak from a single-shell tank. In most cases the liquid that is transferred to a double-she11 tank has a greatly reduced leak potential compared to leaving it in a singleshell tank.

5. The jet pumping cost/benefit ratio is comparatively very high: about $\$ 70,000 /$ man-rem reduction of potential doses from maximum liquid leaks compared to the norma17y accepted $\$ 1000 /$ man-rem reduction to satisfy ALARA needs.

6. Available information shows that jet pumping will not preclude in-situ disposal. Intensive efforts would be needed to demonstrate disposal techniques in conjunction with a change in the jet-pumping orogram. Sufficient details of in-situ disposal methods are not available to definitively evaluate whether jet pumping has adverse effects on disposal. 


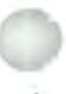

(b) 


\section{APPENDIX A}

BRIEF DESCRIPTION OF HYDROLOGIC MODELS AND MOOEL OUTPUT 
BRIEF DESCRIPTION OF HYDROLOGIC MODELS AND MODEL OUTPUT

\section{A.1 VARIABLE THICKNESS TRANSIENT (VTT) GROUND-WATER HYDROLOGIC MODEL}

Any modeling effort requires some simplifying assumptions to bridge the gap between reality and our current knowledge or understanding of the system being modeled. In most modeling fields, certain basic simplifying assumptions are routinely accepted, whereas others require justification based on data gathered and observations made on the real-world system being modeled. For the ground-water hydrologic model used for this report, an extensive modeling effort and associated assumptions have already been made (cf., Bear 1972). The set of assumptions and modeling effort discussed in Chapter 4.0 of Bear's report go from the complex world of porous media particles and the associated tortuous flow paths for ground water to the regime of representative elementary volumes and the fluid-flow continuum. These assumptions are generally accepted in the field of ground-water hydrology and are complex enough that they will not be presented here. The equations that are written to describe an aquifer system will be for a fluid-flow continuum in porous media. However, it is not sufficient for a mathematical model to be based on a sound set of equations which describe the physical system. The model must also be based on technically sound hydrologic information and reasonable simplifying assumptions regarding these hydrologic interpretations. The advent of high-speed digital computers has paved the way for making computer simulation of complex groundwater systems a practical reality.

The digital computer model is designed to simulate the hydrauiic-head response to natural and man-made aquifer stresses in a multilayered twodimensional aquifer system. The real ground-water system is, of course, a three-dimensional system, consisting of precipitation percolating from the surface through unsaturated soil into the uppermost aquifer. In some cases along rivers or streams or at the base of lakes and ponds, the aquifers are discharging into or being recharged from these surface-water bodies. These 
conditions formulate one type of boundary condition for the mathematical model. The units called separate aquifers are really water-saturated layers in the soil and rock matrix which make up the earth's crust (Figure A.1). These units are generally more permeable than the geologic units directly below them and sometimes more permeable than those above. As a result, the water in an aquifer tends to flow in a horizontal direction along the bedding plane of the more permeable geologic formation since the resistance to flow is 1ess. The less permeabie (aquitard) or sometimes impermeable (aquiclude) layers below, and sometimes above, the aquifer materials retard or completely block the vertical flow. These less permeable layers are designated as the base and top of the aquifer unit. When a more permeable layer exists below the upper aquifer unit's base, another aquifer may exist. When the aquitard material between aquifers is somewhat permeable, there can be water transfer between the aquifer units, depending on the water potential or pressure in the units. For most of the regional ground-water models currently in use, a simplifying assumption is made which tranforms this three-dimensional system to a layered two-dimensional system with interaquifer transfer via a potentialdriven leakage term. The mathematical model which utilizes this set of simplifying assumptions is the multiaquifer formulation of Boussinesq equations.

The conceptual Hanford Ground-Water Model (Kipp et al. 1976) utilizes the known geology through a variable hydraulic conductivity distribution developed from pump tests, the aquifer bottom, and the water-table elevations. The computer code, Variable Thickness Transient (VTT) (Reisenauer 1979) GroundWater Model, is designed to simulate the hydraulic-head response to natural or man-made stress in an aquifer system. Details of the mathematical formulation and usage will be found in Kipp et a1. (1976) and Reisenauer (1979) and will not be repeated here.

\section{A.1.1 Assumptions}

The basic assumptions of the Boussinesa flow model for describing saturated unconfined flow are:

- Flow is generated by an incompressible fluid that saturates a rigid, porous soil matrix. 


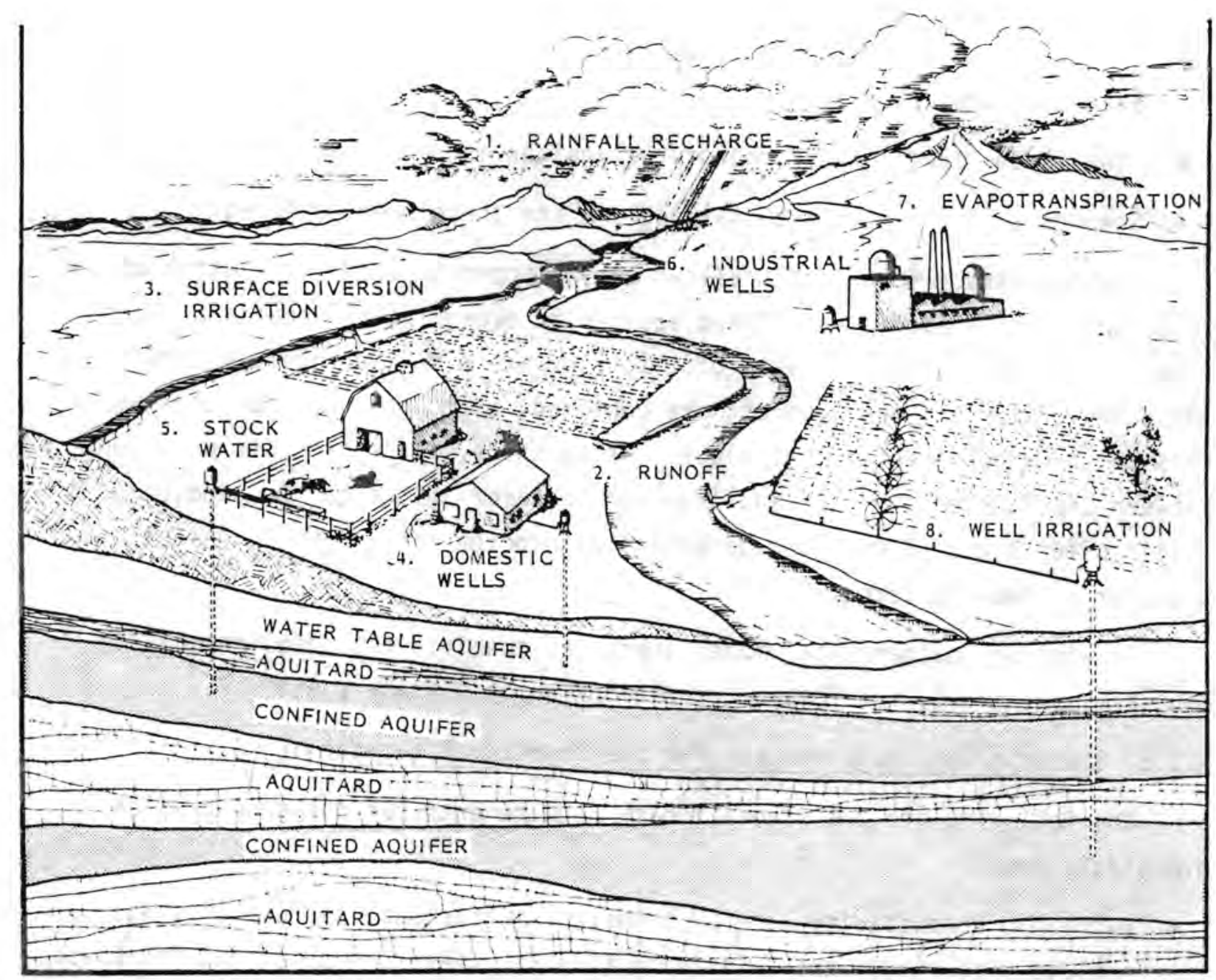

FIGURE A.1. Nodal Recharge/Withdrawal Phenomena

- Compressibility effects of the fluid and soil matrix can be neglected under conditions of unconfined or free-surface flow; however, they are incorporated into the storage term for confined flow.

- Hydraulic conductivity and effective porosity can be represented by the vertical average values and are isotropic but inhomogeneous throughout the region.

- The free-surface slope and the aquifer bottom slope are both assumed to be slight $\left(<5^{\circ}\right)$. 
- Vertical velocities are assumed to be small and therefore can be neglected.

- Coefficient distributions and dependent variables are assumed continuous over the simulation region.

- Flow in the capillary fringe of the aquifer is neglected.

- Seepage surfaces cannot be handled and are therefore neglected.

The Boussinesq formulation allows one to approximate the elevation of the free surface in a single unconfined aquifer at every $(x, y)$ location. Many times in a real system, it is helpful to simulate a multiaquifer system, in which one or more of the aquifers are confined, although these confined aquifers may be unconfined in some places. Also there may be transfer of water between the aquifers. This kind of a multiaquifer system can be handled by a multiaquifer set of Boussinesq equations with potential driven interaquifer transfer or leakage terms.

As with any mathematical model there are specific data requirements, boundary conditions, and initial conditions which must be specified.

\section{A.1.2 Specific Data Requirements for the Physical Parameters}

The following are the specific data requirements for the ground-water hydroiogic model:

- Hydraulic conductivity $(K=k / \mu$, where $k=$ intrinsic permeability and $\mu$

= fluid viscosity); transmissivity $(T=K b$, where $b=$ saturated thickness of the aquifer material).

The Boussinesq flow model requires as an input the saturated hydraulic conductivity or transmissivity distribution throughout the region being modeled and for each aquifer being modeled. The values required by the Boussinesq model must represent the vertical average of the $K$ or $T$ of the saturated thickness of the aquifer.

Hydraulic conductivity or transmissivity reflects the ability of the rock and soil matrix to allow water transmission. The $K$ or $T$ distribution is usually determined via appropriately conducted pumping tests, where the well is fully penetrating and perforated throughout saturated aquifer 
material. Data from these types of field measurements are expensive to obtain, and therefore the $K$ or $T$ distribution is extrapolated from a small number of these measurements. This initial distribution is further modified during the model-calibration phase to obtain better agreement between model-predicted potentials and observed potentials. Hydraulic conductivity can also be estimated from laboratory studies of aquifer material samples, lithologic data and inverse mathematical modeling methods.

- Storage coefficient (or effective porosity $n_{e}$ and vertical compressibility of the soil matrix $[a])$.

The transient form of the Boussinesq equation requires the distribution of the vertical averaged value of the storage coefficient for each aquifer throughout the region being modeled. This parameter controls the rate at which the water and disturbances in the potential surface propagate throughout the ground-water system. In the case of an unconfined systam, the storage coefficient is dominated by the effective porosity of the aquifer's soil matrix.

Contributions to the storage coefficient based on soil-matrix compressibility and water compressibility are ignored. In the case of confined systems, the storage is a function of the aquifer soil-matrix compressibility $(\alpha)$, effective porosity $\left(n_{e}\right)$, with storage $=p g\left(\alpha+n_{e} \beta\right)$.

Storage or effective porosity can be determined via pumping tests with observation wells, lithologic data from core samples, and laboratory or in-situ measurement techniques. In addition, storage coefficients can be determined during model calibration when adequate transient data on potentials exist.

- Interaquifer transfer coefficients $\left(C_{j \rightarrow i}\right)$

The multiaquifer Boussinesq Flow Model requires an interaquifer transfer coefficient, which is a measure of the hydraulic interconnection between aquifer systems. This value is a function of the thickness and hydraulic conductivity of the aquitard separating the aquifer systems; it must be determined at each $(x, y)$ location where an aquitard exists between the 
aquifers. This value arises naturally in the other three-dimensional

formulations in the form of $(x, y, z)$ hydraulic conductivity distributions.

It is generally obtained via model calibration of inverse modeling techniques.

Initial Conditions

The Boussinesq flow model requires initial conditions. The Boussinesq flow model requires one average potential value for each aquifer for each ( $x$, y) grid location throughout the region being modeled.

Boundary Conditions

Like all mathematical models, the Boussinesq model requires that boundary conditions be specified. Boundary conditions are difficult to formulate and result from interpretations of potential data, well logs, and lithologic data. The physical extent of the aquifer and or aquifers are defined. This includes a geometrical description of the positions in space of the aquifer materials such as:

- the lateral boundaries of the aquifer or aquifer systems

- contour maps of the base and top of the aquifer or aquifer systems.

Along each of the lateral boundaries, the conditions which describe the physical situation which exists must be determined. These include:

Lateral-Flow Boundary. This results from not extending the model to the geologic boundaries of the aquifer or aquifer systems. At these boundaries the rate that water is flowing into or out of the aquifer system must be specified.

No-Flow Boundaries. These occur when the model has been extended to the geologic boundaries of the aquifer where the aquifer materials and impermeable barriers meet.

Held or Time-Varying Potential Boundaries. These occur at large lakes and rivers, where the saturated aquifer materials are in contact with large bodies of water whose water surface elevations are essentially unaffected by aquifer potentials.

A. 6 


\section{A.1.3 Recharge - Discharge Locations and Rates}

Typically, when modeling an aquifer system which extends to the major recharge areas, the following types of data are used to estimate aquifer recharge:

- precipitation records

- surface slope

- temperature record

- surface soil types

- vegetation cover and land use

- evapotranspiration data.

Man-made recharge or discharge must also be accounted for by determining:

- location of pumping and recharge wells

- use of water and infiltration mechanisms (e.g., septic tanks, irrigation infiltrations, settling ponds).

Along flow boundaries where the area being modeled does not extend to geologic boundaries, the flow across this boundary must be determined via pump test and geologic studies conducted along this boundary.

Figure A.1 illustrates graphically the phenomena which must be considered in calculating the distribution of aquifer stress values throughout the region being modeled.

\section{A.2 MULTICOMPONENT MASS TRANSPORT (MMT) MODEL}

The MMT model uses a random walk form of the method of characteristics to numerically solve the transport equation. In this method, the convection and dispersion are simulated separately through the movement of a large number of parcels. Each of these parcels represents a small fraction of the total mass to be leached into the ground-water system. The amount of mass to be released is determined from the unsaturated, flow-column simulation, release-rate characterization that was dependent on the geology. The release source term curve reflects the details of the release scenario and is the primary factor for establishing the initial radionuclide concentrations during transport simulation. 
Without the effects of sorption and dispersion, released concentration levels propagate along the flow tube with the ground-water flow velocity, altered only by radioactive decay. Sorption differences among nuclides and dispersion cause separation in the concentration distributions. Another factor determining the initial radioisotope concentrations is the distribution of the source in the flow field. The MMT allows this source distribution to be accounted for by specifying a release center and release length. Parcels of mass released are then released uniformly over the extent of this source area. Specific input data requirements and mathematical details for MMT are described in Washburn et a1. (1978).

\section{A.2.1 Data Requirements for Multicomponent Mass Transport}

The data required by the MMT code include the following:

- Repository release characterization

- time of release into the ground-water aquifer

- release source-term description

- initial inventory

- radioactive decay constants (half-lives) for all nuclides in the inventory

- Flow-tube characterization

- description of the path to the biosphere release point

- flow-tube length

- flow dimensions, width, height

- flow-tube porosity

- ground-water velocity

- actual or effective dispersion in the longitudinal direction, lateral and hydrodynamic dispersion in the transverse directions

- Nuclide retardation data

- distribution coefficient (Kd)

- beta-ratio of the bulk mass density to porosity for unconsolidated granular deposits. 


\section{A.3 MODEL OUTPUT DATA}

Figures A.2 through A.4 illustrate the type of data as output from the modeling effort; Figure A.2 is for the no pumping case and $B$ tank farm, and shows the arrival time at the Columbia River and rate of the technetium-99 discharge. Figures A.3 and A.4 are similar except for iodine-129 and neptunium-237, respectively. Curves simiiar to these were obtained for all cases, tank farms and for each of the three radionuclides of interest (not included in this report). Table A.I is a summary of the data contained from al1 of the curves.

\section{TABLE A.1. Summary of Radionuclide Transport} Modeling to the Columbia River

Terminate Pumping Immediately

\begin{tabular}{l} 
Initial Release (a) $\begin{array}{l}\text { Duration of } \\
\text { Release (Num- Peak Release Rate } \\
\text { to River (Ci/yr) }\end{array}$ ber of years) \\
\hline
\end{tabular}
Tank Farm Radionuclide to River (Ci/yr) ber of vears)

$\begin{array}{cccrc}A \text { and C } & { }^{99} \mathrm{TC} & 94 & 124 & 38 \\ & { }^{129} \mathrm{I} & 94 & 124 & 5.7 \times 10^{-2} \\ & { }^{237} \mathrm{~Np} & 5.0 \times 10^{3} & 7,000 & 1.9 \times 10^{-4} \\ \mathrm{~B} & { }^{99} \mathrm{TC} & 44 & 26 & 600 \\ & { }^{129} \mathrm{I} & 44 & 26 & 1.1 \\ & 237 \mathrm{~Np} & 2.4 \times 10^{3} & 1,400 & 2.6 \times 10^{-3} \\ \mathrm{~S} & { }^{99} \mathrm{TC} & 87 & 16 & 780 \\ & 129 \mathrm{I} & 87 & 16 & 1.3 \\ & 237 \mathrm{~Np} & 4.6 \times 10^{3} & 600 & 3.5 \times 10^{-3} \\ \mathrm{~T} & 99 \mathrm{TC} & 168 & 48 & 220 \\ & 129 \mathrm{I} & 168 & 48 & 0.32 \\ & 237 \mathrm{~Np} & 9.4 \times 10^{3} & 2,600 & 8.3 \times 10^{-4}\end{array}$

(a) Assumes all tanks leak entire drainable liquid in the year 2000. Values are years after initial release when the radionuclide first reaches the Columbia River. 
Table A.1 (continued)

Terminate Pumping Immediately

Initial Release (a) Ruration of ${ }^{\text {Release (Num- Peak Release Rate }}$

Tank Farm Radionuclide to River ( $\mathrm{Ci} / \mathrm{yr})$ ber of years) $(\mathrm{Ci} / \mathrm{yr})$ u ${ }^{99} \mathrm{TC}$
${ }^{129} \mathrm{I}$
${ }^{237} \mathrm{~Np}$

\section{0}

120

$6.4 \times 10^{3}$

27

27

1,300

Pump to 100,000 -gal Limit

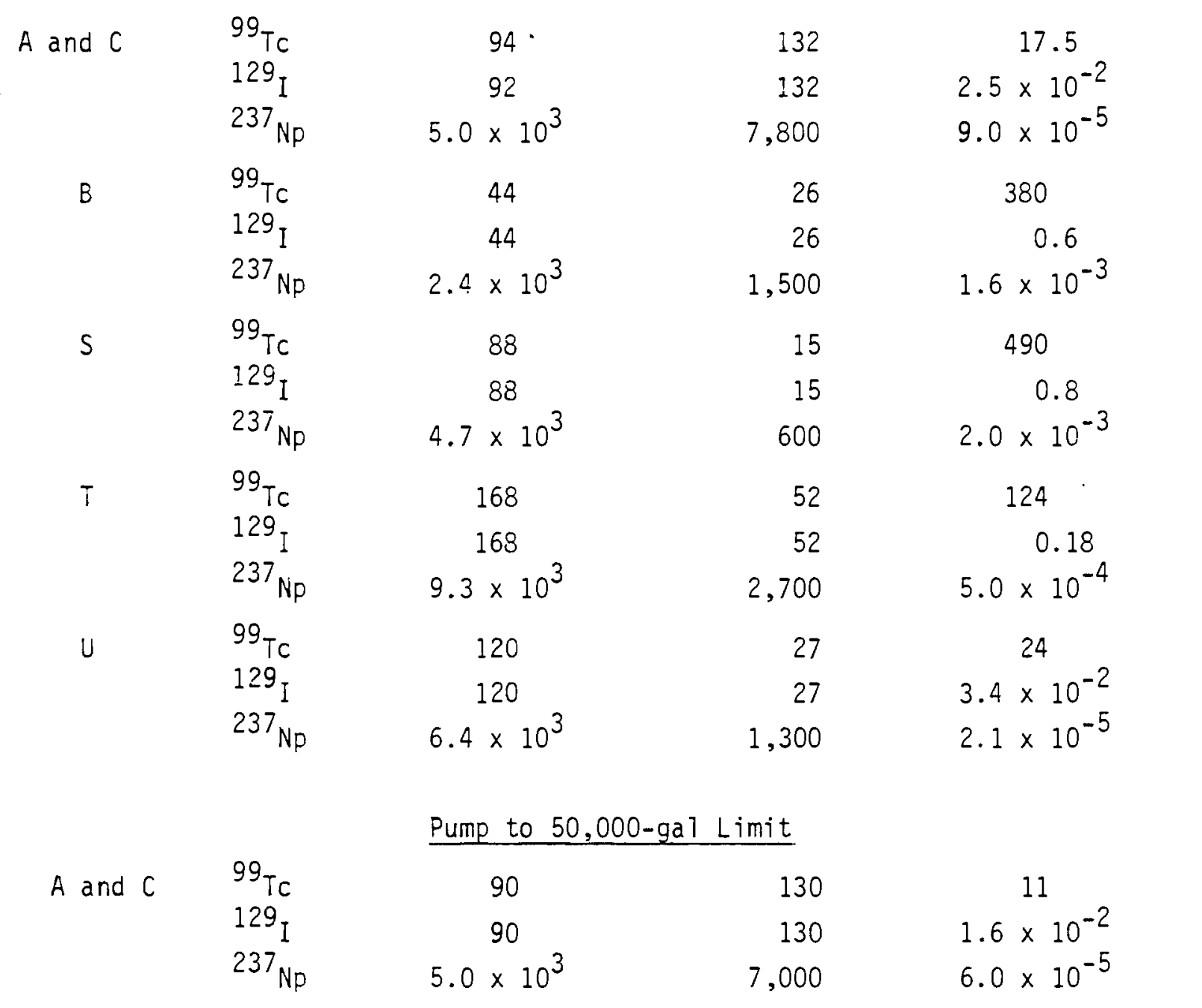


Tabie A.1 (continued)

\begin{tabular}{|c|c|c|c|c|}
\hline Tank Farm & Radionuclide & $\begin{array}{l}\text { Initial Release }{ }^{(a)} \\
\text { to River }(C i / y r) \\
\end{array}$ & $\begin{array}{l}\text { Duration of } \\
\text { Release (Num- } \\
\text { ber of years) }\end{array}$ & $\begin{array}{c}\text { Peak Release Rate } \\
(\mathrm{C} i / \mathrm{yr})\end{array}$ \\
\hline & \multicolumn{4}{|c|}{ Pump to 50,000 -gal Limit } \\
\hline \multirow[t]{3}{*}{ B } & \multirow{3}{*}{$\begin{array}{l}{ }^{99} \mathrm{TC} \\
{ }^{129} \mathrm{I} \\
{ }^{237}{ }_{\mathrm{Np}}\end{array}$} & 48 & 22 & 240 \\
\hline & & 48 & 22 & 0.37 \\
\hline & & $2.4 \times 10^{3}$ & 1,300 & $1.0 \times 10^{-3}$ \\
\hline \multirow[t]{3}{*}{$s$} & \multirow{3}{*}{$\begin{array}{l}{ }^{99}{ }_{T C} \\
129 \mathrm{I} \\
237_{\mathrm{Np}}\end{array}$} & 88 & 15 & 270 \\
\hline & & 88 & 15 & 0.44 \\
\hline & & $4.7 \times 10^{3}$ & 600 & $1.8 \times 10^{-3}$ \\
\hline \multirow[t]{3}{*}{$T$} & \multirow{3}{*}{$\begin{array}{l}{ }^{99} \mathrm{TC} \\
129 \mathrm{I} \\
{ }^{237} \mathrm{~Np}\end{array}$} & 168 & 49 & 78 \\
\hline & & 168 & 49 & 0.11 \\
\hline & & $9.3 \times 10^{3}$ & 2,900 & $3.0 \times 10^{-4}$ \\
\hline \multirow[t]{3}{*}{ u } & \multirow{3}{*}{$\begin{array}{l}{ }^{99} \mathrm{TC} \\
129 \mathrm{I} \\
237_{\mathrm{NP}}\end{array}$} & 120 & 28 & 13.4 \\
\hline & & 120 & 28 & $1.9 \times 10^{-2}$ \\
\hline & & $6.4 \times 10^{3}$ & 1,300 & $1.2 \times 10^{-5}$ \\
\hline \multicolumn{5}{|c|}{ Pump to Maximum Liquid Removal (30,000-gàl Limit) } \\
\hline \multirow[t]{3}{*}{$A$ and $C$} & \multirow{3}{*}{$\begin{array}{l}{ }^{99} \mathrm{TC} \\
{ }^{129} \mathrm{I} \\
237 \mathrm{~Np}\end{array}$} & 90 & 110 & 14 \\
\hline & & 90 & 110 & $2.1 \times 10^{-2}$ \\
\hline & & $5.0 \times 10^{3}$ & 7,000 & $6.4 \times 10^{-5}$ \\
\hline \multirow[t]{3}{*}{ B } & \multirow{3}{*}{$\begin{array}{l}{ }^{99} \mathrm{Tc} \\
{ }^{129} \mathrm{I} \\
237 \mathrm{~Np}\end{array}$} & 44 & 24 & 112 \\
\hline & & $44^{\circ}$ & 24 & 0.18 \\
\hline & & $2.4 \times 10^{3}$ & 1,400 & $4.4 \times 10^{-4}$ \\
\hline \multirow[t]{3}{*}{$\mathrm{s}$} & \multirow{3}{*}{$\begin{array}{l}{ }^{99} \mathrm{TC} \\
129_{\mathrm{I}} \\
237_{\mathrm{Np}}\end{array}$} & 88 & 15 & 140 \\
\hline & & 88 & 15 & 0.2 \\
\hline & & $4.7 \times 10^{3}$ & 600 & $5.4 \times 10^{-4}$ \\
\hline \multirow[t]{3}{*}{ T } & \multirow{3}{*}{$\begin{array}{l}{ }^{99} \mathrm{Tc} \\
{ }^{129} \mathrm{I} \\
{ }^{237} \mathrm{~Np}\end{array}$} & 168 & 52 & 30 \\
\hline & & 168 & 52 & $5.0 \times 10^{-2}$ \\
\hline & & $9.3 \times 10^{3}$ & 2,900 & $1.0 \times 10^{-4}$ \\
\hline \multirow[t]{3}{*}{ U } & \multirow{3}{*}{$\begin{array}{l}{ }^{99} \mathrm{TC} \\
129 \mathrm{I} \\
237_{\mathrm{Np}}\end{array}$} & 120 & 26 & 6.8 \\
\hline & & 120 & 26 & $9.5 \times 10^{-3}$ \\
\hline & & $6.4 \times 10^{3}$ & 1,300 & $5.0 \times 10^{-6}$ \\
\hline
\end{tabular}




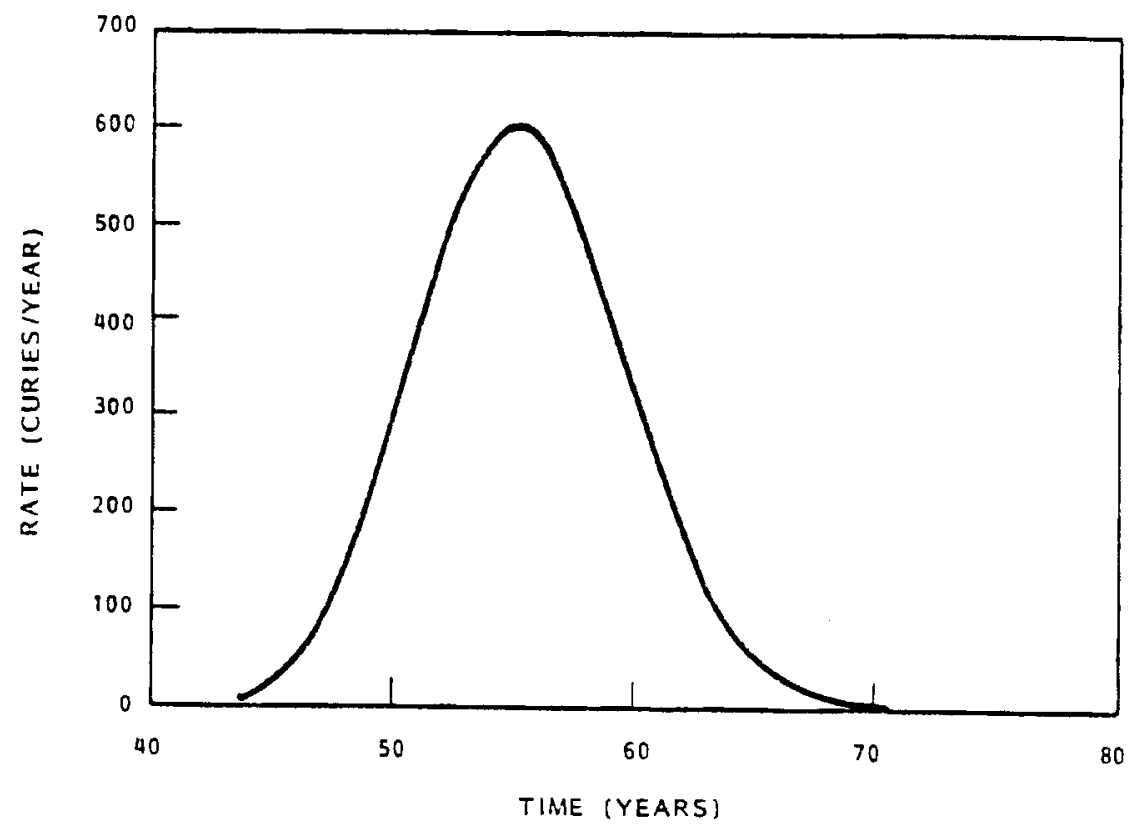

FIGURE A.2. Data Output from Flow Modeling of the B Tank Farm for Terminating Pumping Immediately $99 \mathrm{TC}$ Isotope

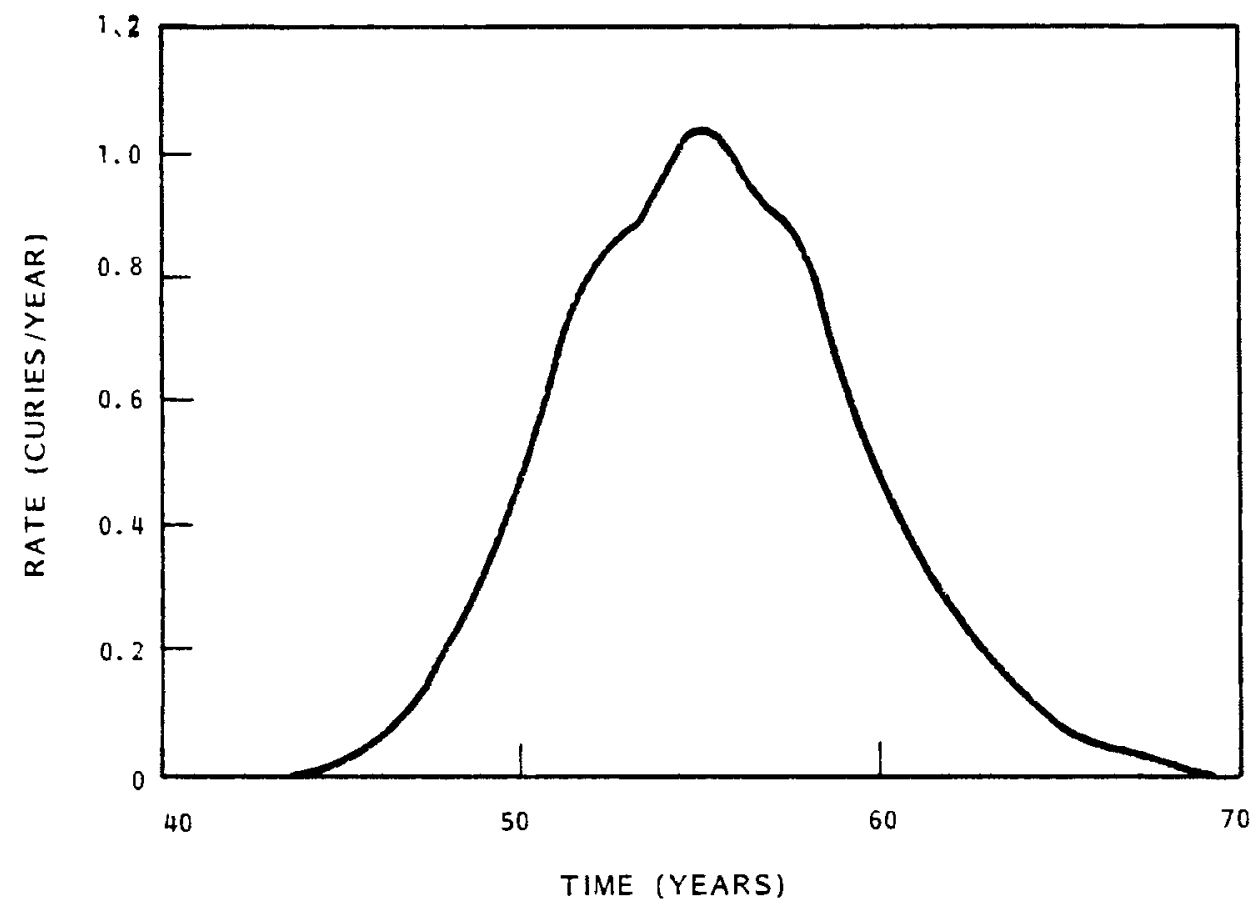

FIGURE A.3. Data Output from Flow Modeling of the B Tank Farm for Terminating Pumping Immediately ${ }^{129}$ I Isotope 


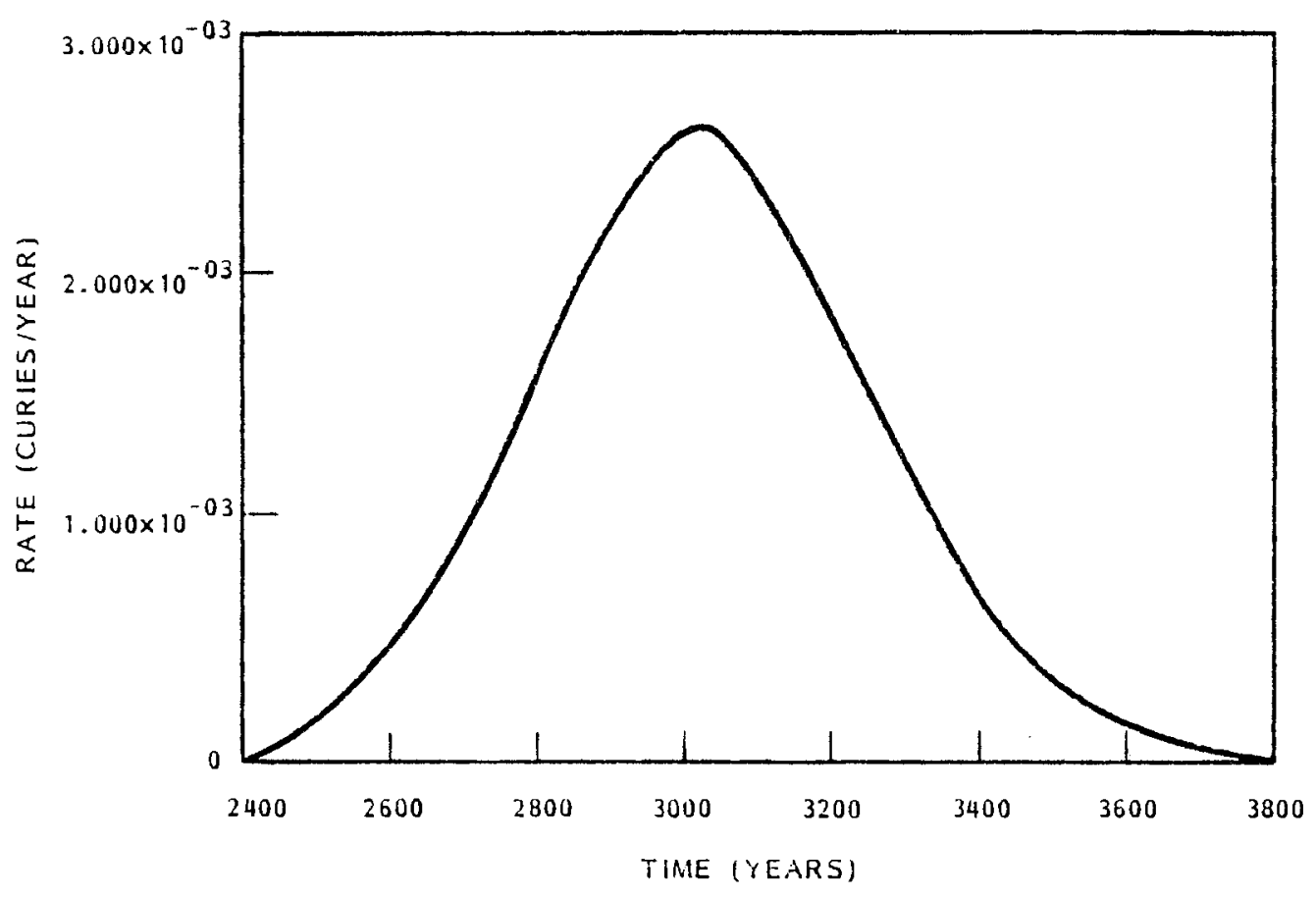

FIGURE A.4. Data Output from Flow Modeling of the B Tank Farm for Terminating

Fumping Immediately $237 \mathrm{~Np}$ Isotope 
APPENDIX B

METHOD FOR CALCULATING RADIATION DOSE ANO CONVERTING TO HEALTH EFFECTS 


\section{APPENDIX B}

METHOD FOR CALCULATING RADIATION DOSE

AND CONVERTING TO HEALTH EFFECTS

The computer programs and input data used in calculating potential radiation doses to members of the general public from jet pumping normal and abnormal operations are discussed below. All of these programs have been separately documented and only a brief summary will be presented here.

Releases of radionuclides from jet-pumping-related facilities can be either low-level releases that continue for a relatively long period of time, or abrupt, usualiy accidental, releases. In addition to direct exposure to material and foods contaminated during the release, exposure will result from residual soil contamination.

Information is provided in this appendix to enable the reader to convert calculated dose to calculated health effects in the population surrounding Hanford. Aiso included is a discussion of the effect that transport of neptunium-237 to the 200 Area ground water would have on long-term popuiation doses.

\section{B.1 COMPUTER PROGRAMS}

The computer programs used to calculate potential radiation doses from releases of radioactive material are summarized in Table B.1; their interrelation is illustrated in Figures B.1, B.2 and B.3.

Computer programs used to calculate dose to a maximally exposed individual and to the regional population from a chronic atmospheric release are shown in Figure B.1. The programs KRONIC (Strenge and Watson 1973) and DACRIN (Houston, Strenge and Watson 1974; Strenge 1975) take information about meteorology and population distribution and calculate air submersion and inhalation doses, respectively, for a given release term. A population weighted value of the annual average air concentration per unit release of radionuclides (chi/Q) calculated as a byproduct of KRONIC is used by the program PABLM (Napier, Kennedy and Soldat 1980), along with information on crops grown localiy, to calculate an accumulated dose from terrestrial pathways.

\section{B. 1}


TABLE B.1. Computer Programs Used to Caiculate Potential

Radiation Doses from Releases of Radionuclides

\begin{tabular}{|c|c|c|}
\hline Program & Type of Dose & Reference \\
\hline KRONIC & $\begin{array}{l}\text { One-yr air submersion dose from chronic releases, } \\
\text { individual and collective }\end{array}$ & $\begin{array}{l}\text { Strenge and } \\
\text { Watson (1973) }\end{array}$ \\
\hline HADOC & $\begin{array}{l}\text { One-yr individual and collective air submersion } \\
\text { and inhalation dose commitments from acute } \\
\text { reieases (semi-infinite cloud model for external } \\
\text { doses) }\end{array}$ & $\begin{array}{l}\text { Strenge and } \\
\text { Peloquin (1980) }\end{array}$ \\
\hline DACRIN & $\begin{array}{l}\text { Individual and collective inhalation doses from } \\
\text { chronic or acute releases, one-yr doses, dose } \\
\text { commitments, and accumulated doses }\end{array}$ & $\begin{array}{l}\text { Houston, Strenge } \\
\text { and Watson (1974) } \\
\text { Strenge (1975) }\end{array}$ \\
\hline PABLM & $\begin{array}{l}\text { Individual and collective doses from contaminated } \\
\text { farm products, from either air deposition or irri- } \\
\text { gation, one-yr dose, dose commitment, and accumu- } \\
\text { lated dose }\end{array}$ & $\begin{array}{l}\text { Napier, Kennedy } \\
\text { and Soldat (1980) }\end{array}$ \\
\hline & $\begin{array}{l}\text { Individual and collective doses from contaminated } \\
\text { water and aquatic foods and aquatic recreation, } \\
\text { one-yr dose, dose commitment, and accumulated dose }\end{array}$ & \\
\hline DITTY & $\begin{array}{l}10,000-y r \text { integrated collective doses from either } \\
\text { atmospheric or aquatic releases }\end{array}$ & $\begin{array}{l}\text { (Documentation } \\
\text { in preparation) }\end{array}$ \\
\hline
\end{tabular}

Figure B.2 illustrates the programs used to calculate doses from acute atmospheric releases of radionuclides. The program HADCC (Strenge and Peloquin 1980) uses meteorology and population data to calculate air submersion and inhalation doses. The inhalation doses are based on dose commitment factors precalculated using DACRIN. The program PABLM calculates the accumulated doses resulting from an acute deposition on crops and from residual environmental contamination.

Figure B.3 illustrates the programs used to calculate long-term integrated collective population doses from variable, long-term releases. The ground-water flow and transport codes VTT and MMT are further described in Appendix A. The program DITTY (document in preparation) is a refined version of PABLM, accounting for long-term environmental buildup and removal of radiocontaminants. 


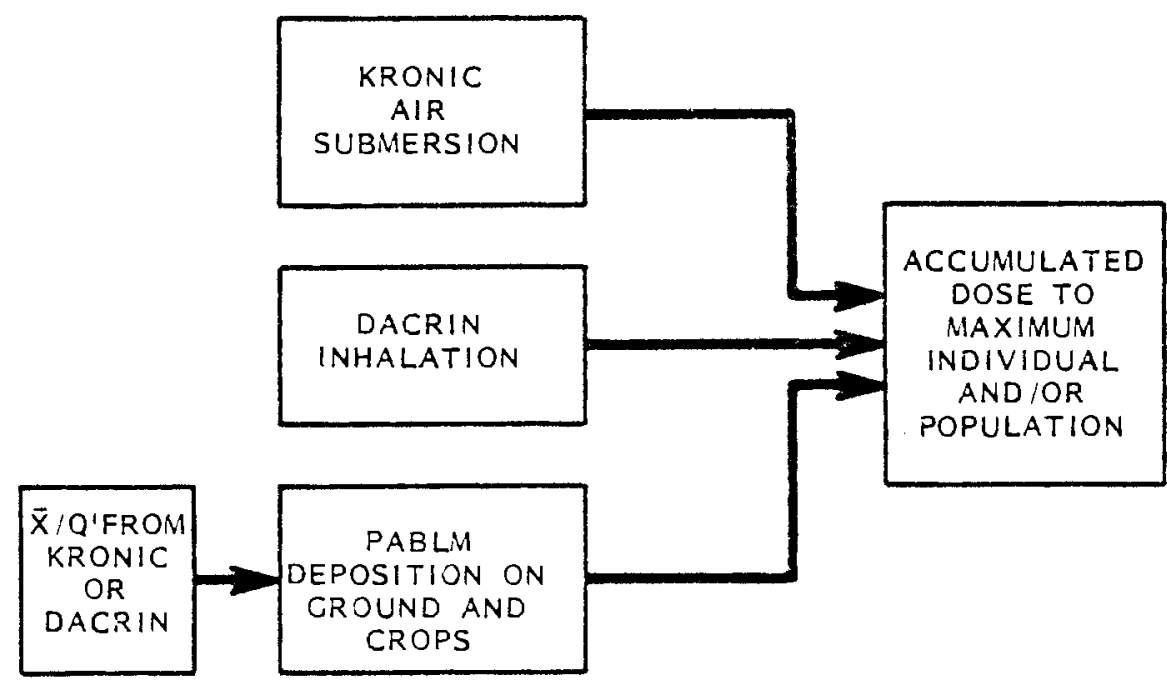

FIGURE B.1. Computer Programs for Calculating Public Doses from Routine Airborne Releases of Radionuclides

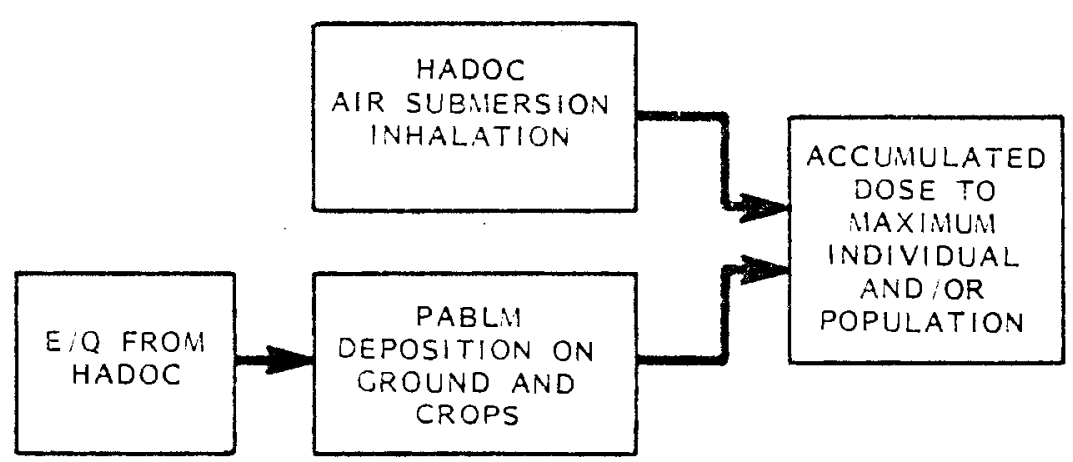

FIGURE B.2. Computer Programs for Calculating Public Doses from Accidental Airborne Releases 


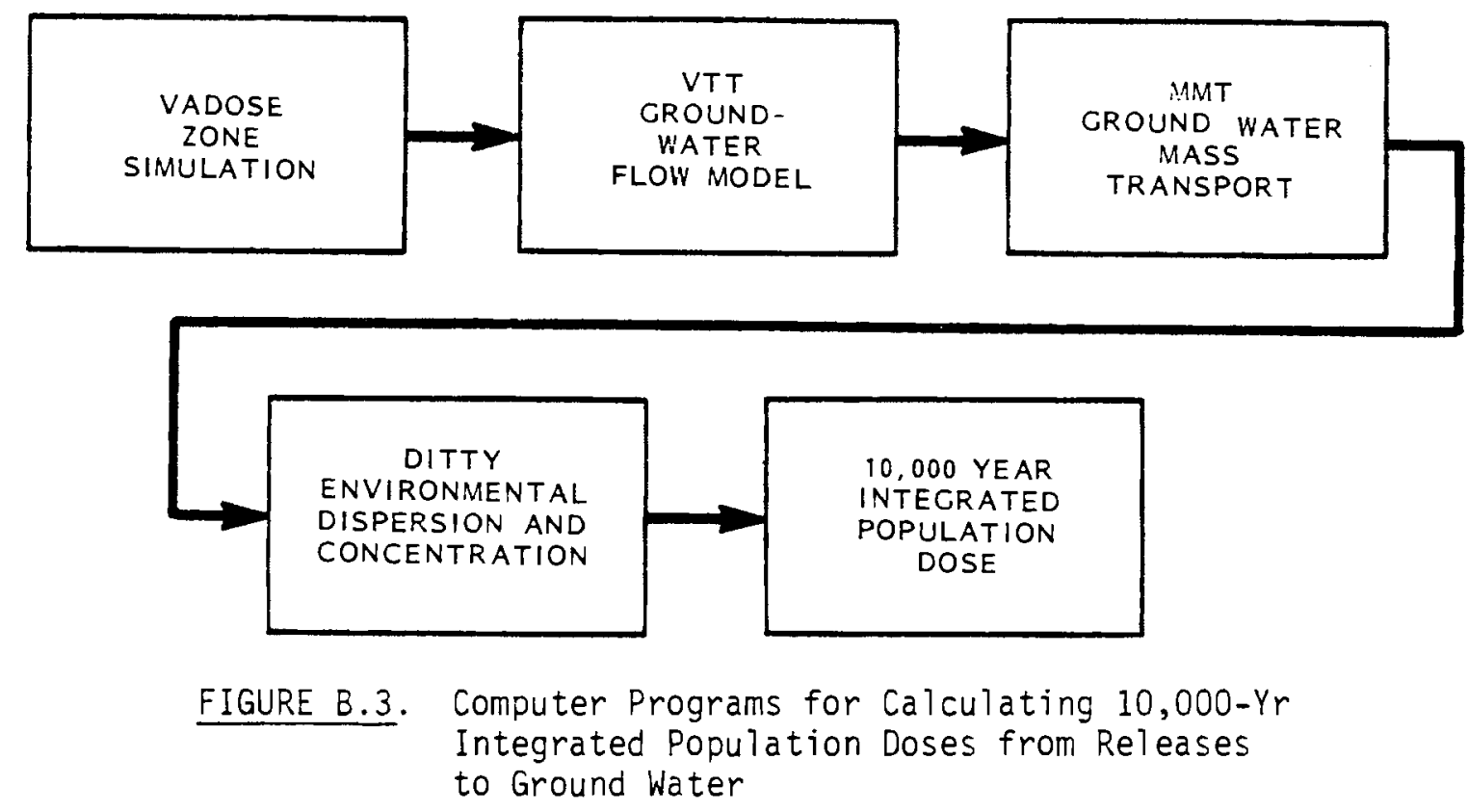

The program DITTY calculates doses with contributions from aquatic pathways such as drinking water, fish, and water recreation, and from terrestrial pathways contaminated with irrigation water, including food crops, animal products, and inhalation of resuspended material. A major enhancement of DITTY made for this study was the inclusion of environmental removal factors for radionuclides in soil.

\section{B.2 STANDARD HANFORD METEOROLOGICAL PARAMETERS}

Meteorological data have been collected at the Hanford Meteorological Station, near the 200-West Area, for the past 30 years. Values of the annual average atmospheric dispersion parameters are available in Hanford Annual Reports (such as Sula et a1. 1982) for the 200-ft release height.

Because the jet-pumping-related facilities are located a significant distance from the nearest residence, a special set of assumptions is usually used to determine the location of the maximum individual for accidental releases. For purposes of inhalation and air-submersion calculations, the maximum individual is assumed to be traveling on Highway $240,5.5 \mathrm{mi}$ southwest of the 200 Areas; but for ingestion calculations, he is assumed to farmin Franklin 
County, $15.5 \mathrm{mi}$ downwind in the southeast direction from the 200 Areas. For chronic releases, the maximum individual is assumed to live continuously on the farm in Franklin County for all pathway calculations.

For acute ground-level releases, the E/Q at the Hanford Highway 240 is $3.0 \times 10^{-5} \mathrm{sec} / \mathrm{m}^{3}$, and at the farm in Frankl in County it is $7.6 \times 10^{-6} \mathrm{sec} / \mathrm{m}^{3}$. The chi/Q value at the farm from chronic releases is $7.4 \times 10^{-9} \mathrm{sec} / \mathrm{m}^{3}$ for ground-level releases.

\section{B.3 STANDARD HANFORD EXPOSURE PARAMETERS}

Data required for the dose programs includes dietary and recreational preferences and habits in the general population, as well as agricultural practices in the general region. The standard Hanford terrestrial pathway data are given in Sula et al. 1982. The growing pericd, yield, and irrigation rate reflect agricultural practices in the Columbia River Basin. The parameters for the average member of the population reflect the dietary habits of Tri-Cities residents. Values used for the maximum individual represent a worst-case individual supporting himself and his family with a large garden and farm animals. Standardized input for Hanford-related dose calculations can be obtained from McCormack (1982) or from Napier (1981).

\section{B.4 HANFORD DEMOGRAPHIC PROJECTIONS}

Several studies have been made on population growth trends for the area around Hanford. The most recent is by Sommer, Rau and Robinson (1981), covering the period up to the year 1990. An earlier study by Yandon, Burlison and Rau (1980), covers the same geographical area, but carries the projections out a full 10,000 yr. It is this projection that was used for this study.

\section{B.5 RADIOLOGICALLY RELATED HEALTH EFFECTS}

The potential radiological impact on persons residing in the environs of the Hanford Reservation from the jet-pumping facilities and potential future waste leaks is given in this study as radiation dose to individual and population groups. The following information is given for the reader interested 
in making conversions to health effects. Less than one health effect would be expected for any of the dose levels reported in this document. Most of this discussion is taken from the detailed discussion found in Appendix $E$ of the Final Environmental Impact Statement on Management of Commercially Generated Radioactive Waste, DOE/EIS-0046F, Vol. 2 (USDOE 1980b).

The radiation dose to man from ingestion, inhalation, or external exposure to specified quantities of radionuclides can be calculated with reasonable confidence. The relationship in so-called "health effects" is less well defined.

The usual practice in making these estimates is that if an error is to be made, it will be made in a way that will overestimate the number of health effects that might occur.

Because expected releases of radionucides are very smal1, and the radiation dose to any individual is smal1, the effects considered are long-delayed somatic and genetic effects. Somatic effects are radiation-induced effects that become manifest in the exposed individual himself; at low doses and dose rates, these are primarily delayed cancers. Genetic effects are those that affect the descendants of the exposed individual; primarily mutations, these are also called "hereditary effects." These effects will occur, if at all, in a very small fraction of the persons exposed. At the dose rates encountered in this report, no possibility exists for an acute radiation health effect. The effects that must be considered are: 1) cancers that may result from whole-body exposures, and more specifically, from radionuclides deposited in lung, bone, and thyroid, and 2) genetic effects that are reflected in future generations because of exposure of germ cells.

Knowledge of these delayed effects of low doses of radiation is necessarily indirect. This is because their incidence is too low to be observed against the much higher background incidence of similar effects from other causes. Thus, for example, it is not possible to attribute any specific number of human cancers to the radionuclides present in everyone's body from weapons test fallout, because such cancers are known to be caused by other materials present in much more hazardous concentrations, and because cancers occurred before there were any man-made radionuclides. Even in controlled 
studies with experimental animals, one reaches a low incidence of effect that cannot be distinguished from the levei of effects in unexposed animals, at exposure levels far higher than those predicted to result from the activities described in this report. Hence, one can only estimate upon observations made at very much higher exposure levels, where effects have been observed in man, and carefully studied animal experiments. In this context the National Council on Radiation Protection and Measurements has said "The NCRP wishes to caution governmental policy-making agencies of the unreasonableness of interpreting or assuming 'upper 1 imit' estimates of carcinogenic risks at low radiation levels derived from linear extrapolation from data obtained at high doses and dose rates, of actual risks, and of basing unduly restrictive policies on such interpretation or assumption" (NCRP 1975, p. 4).

A range encompassing commonly used cancer risk factors is given in Table B.2. At the same time the possibility of zero risk at very low exposure levels is not excluded by the available data. The lower range of risk estimates in Table 8.2 may be considered more appropriate for comparison with other risks. The upper part of the range may be more appropriate for radiation protection considerations.

TABLE B.2. Health Effects Risk Factors Recommended in DOE/EIS-0046F (USDOE 1980b)

\begin{tabular}{lr} 
Type of Risk & $\begin{array}{c}\text { Predicted Incidence } \\
\text { per } 10^{6} \text { man-rem }\end{array}$ \\
\hline Fatal cancers from: & 50 to 500 \\
Total body exposure & 5 to 50 \\
Lung exposure & 2 to 10 \\
Bone exposure & 3 to 15 \\
Thyroid exposure & \\
Specific genetic effects & \\
to all generations from & 50 to 300 \\
tota! body exposure & 100 to 800 \\
Total &
\end{tabular}


A range of 50 to 300 specific genetic effects to all generations per million man-rem is also listed in the table. As in the case of the somatic risks, the lower end of the range may be considered more appropriate for comparative risk evaluations, while the upper end of the range may be more appropriate for radiation protection considerations.

The conversion factors may be applied to collective (worker and public) total-body doses from routine and accident situations as discussed in Chapter 5.0. Other conversion factors may be found in the literature. Some would indicate more effects, and others less, not excluding zero health effects.

\section{B. 6 CONSEQUENCES OF NEPTUNIUM-237 TRANSPORT TO RIVER}

As discussed in Chapter 4.0 (Section 4.1), the only radionuclides expected to reach the ground water beneath the tank farms in the event of tank leaks are the unsorbed (low Kd) nuclides technetium-99 and iodine-129. The only other dosimetrically important radionuclide present in IL in sufficient quantity and with sufficiently low Kd to possibly escape is neptunium-237. Unsaturated zone calculations indicate that there is insufficient liquid in the tanks to draw the neptunium as far as the ground water, but that the liquid quantity required to do so is not much greater than what is present. As a parametric study, radiation dose calcuiations were performed for this study to examine the increase in the radiological impact that would occur should the neptunium237 reach the ground water.

Integrated population doses from the release of technetium-99, iodine-129, and neptunium-237 to the ground water for each of the pumping termination volumes of this study are presented in Table B.3. As in Chapter 5.0, doses are given for each tank farm grouping, assuming that ali drainable liquids remaining escape the tanks. Comparison of the results in Table B.3 with those shown in Table 5.7 shows that the addition of neptunium-237 to the ground water does not have a major effect in increasing the doses to the critical organs. Doses to the organs: total body, bone, and lung are increased by about a factor of three. Doses to the critical organs: thyroid and GI-LLI are not noticably affected. 
TABLE B.3. Integrated Population Doses Over 10,000 Years

Resulting from Leakage of Interstitial Liquids (including $237 \mathrm{~Np}$ fraction) at Various Pumping Termination Levels

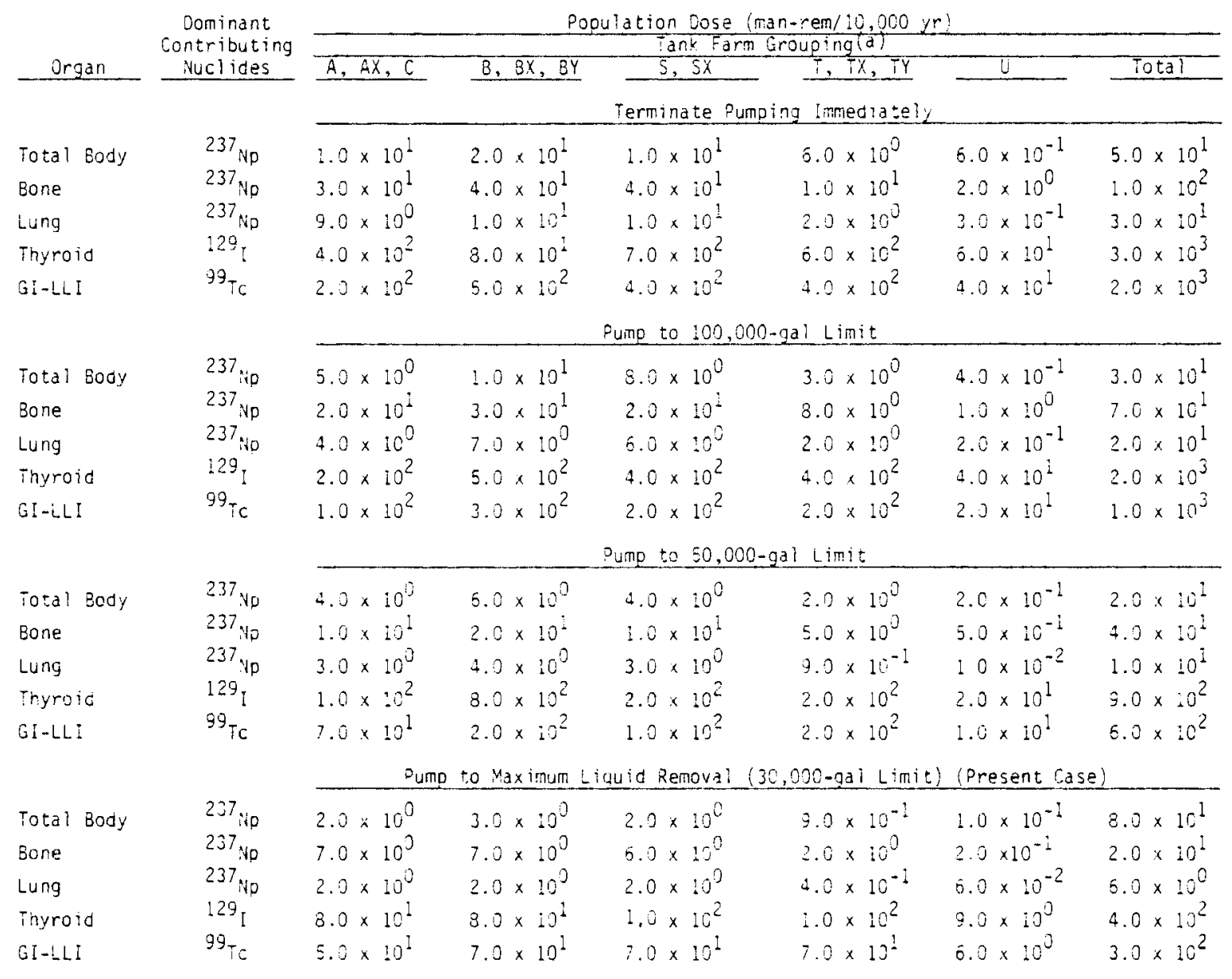

(a) See text.

The rate of accumulation of dose is shown for all organs in Figures 5.1 through 5.5. Many factors are evident in these figures. The nuclides technetium-99 and iodine-129 are the most mobile in the ground water and are thus the first to arrive at the river. They come out in a large pulse about 100 to $300 \mathrm{yr}$ following the initiation of the tank leaks, depending on the 
distance of each tank farm group from the river. These pulses result in the highest dose rates to people living at those future times. Because these two nuclides are so environmentally mobile, they eventually wash into the deeper soil zones or back into the river, are lost to the accessible environment, and therefore the dose rate decreases. The next most mobile radionuclide to arrive at the Columbia River is neptunium-237. This nuclide is held up moderately by its sorptive properties, and so comes out in a very low, broad peak starting about $2,400 \mathrm{yr}$ to $4,000 \mathrm{yr}$ after the leak. The dose rates to future individuals from the neptunium-237 are much lower than what their predecessors received from the technetium-99 and iodine-129, but since the neptunium-237 is much less mobile, it is retained in the soil much longer. Also, since the future population is assumed to be much larger than the present one, the total dose in man-rem is increased. The neptunium release peak results in a brief, sharp, upturn in the dose rate caused by assumed irrigation and subsequent foliar deposition. The dose rate at 10,000 yr has decreased to nearly the original background rate so that dose rate shown falls back to near zero. Figures B.1, B.2, and B.3 show this behavior best. Figures B.4, B.5, and $B .6$ show the organ-dependence of radionuclides on the calculations. In Figure B.7 the jodine-129 is preferentially taken up by the thyroid, much more so than the neptunium, so most of the thyroid dose occurs to an integrated population relatively soon after the tanks are assumed to leak. The same is true for the GI-tract dose, which is dominated by technetium-99 as shown in Figure B.8.

Also of interest, is the time period at which the dose rate to an individual is the highest. Although for total body dose, the radionuclide contributing the most over the 10,000-yr period is the neptunium-237, the largest dose rate to individuals occurs before any neptunium can migrate as far as the river. The highest individual doses occur during the peaks of the iodine-129 and technetium-99, about $150 \mathrm{yr}$ after the tanks leak. Peak lifetime dose rates to individuals are given in Table 5.8, for the most likely case where the neptunium-237 does not reach the river. Even if the neptunium-237 were to reach the river, it would not get there until long after the technetium-99 and iodine-129 peaks have passed. Since the iodine and technetium are the major dose contributors to the critical organs, the later superimposition of the 


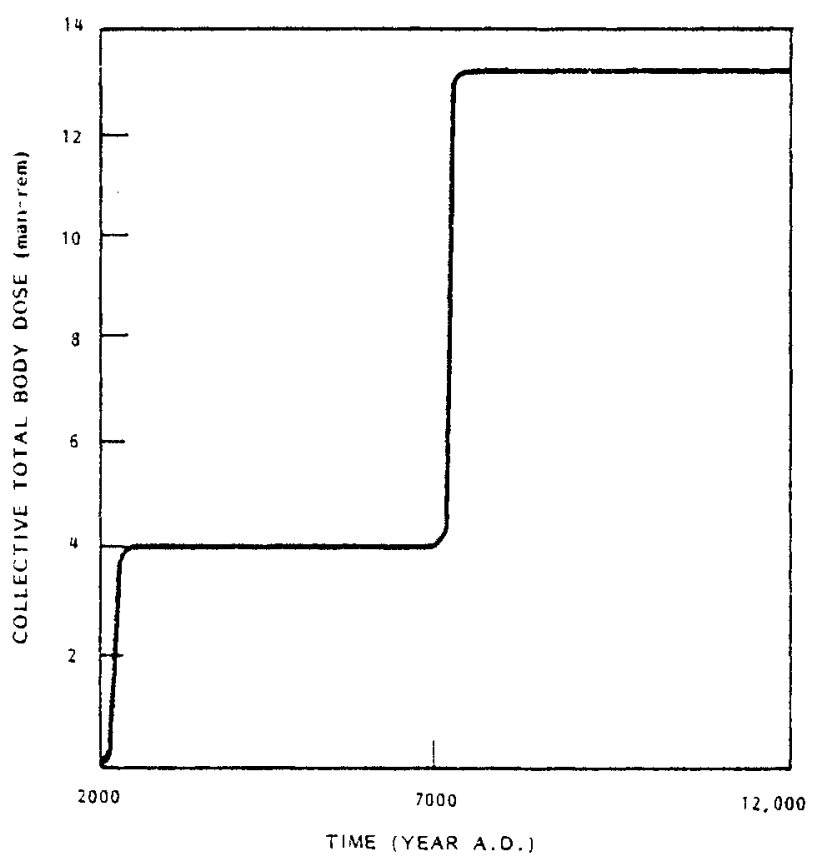

FIGURE B.4. Integrated Collective Total Body Dose from Leakage from the $S$ and SX Farms, Terminate Pumping Immediately Option

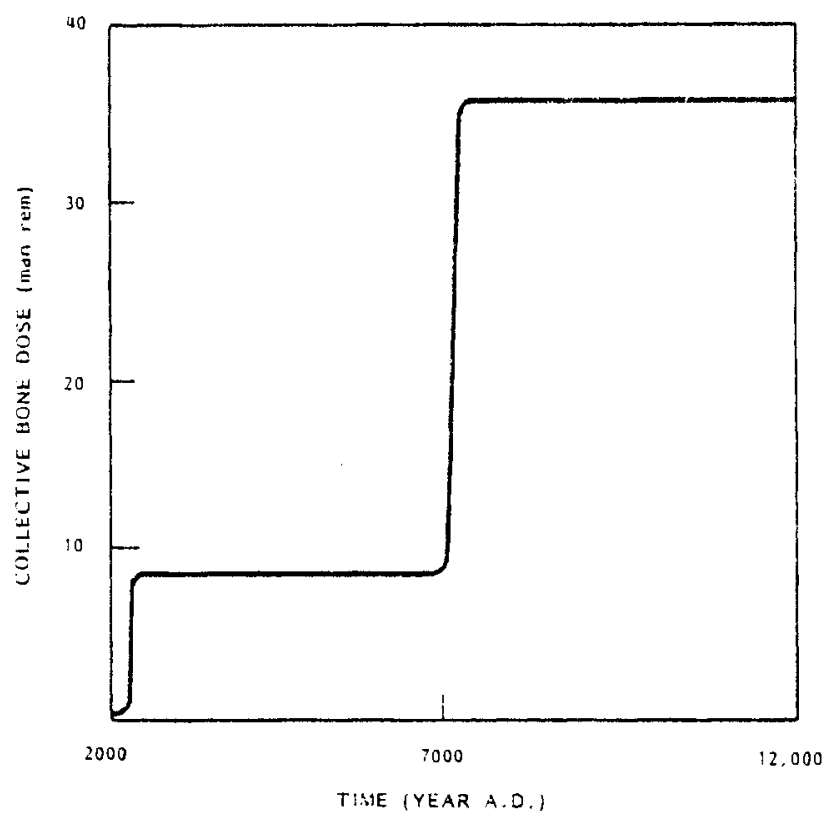

FIGURE B.5. Integrated Collective Bone Dose from Leakage from the $S$ and SX Farms, Terminate Pumping Immediately Option

B. 11 


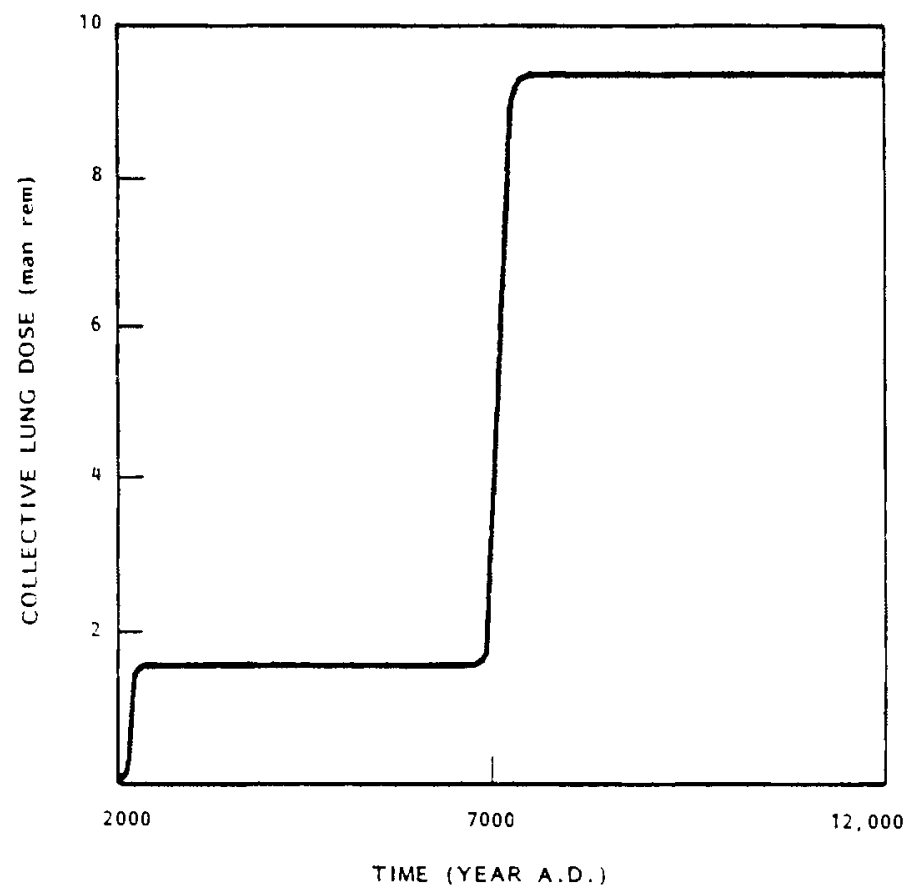

FIGURE B.6. Integrated Collective Lung Dose from Leakage from the $S$ and SX Farms,

Terminate Pumping Immediately Option

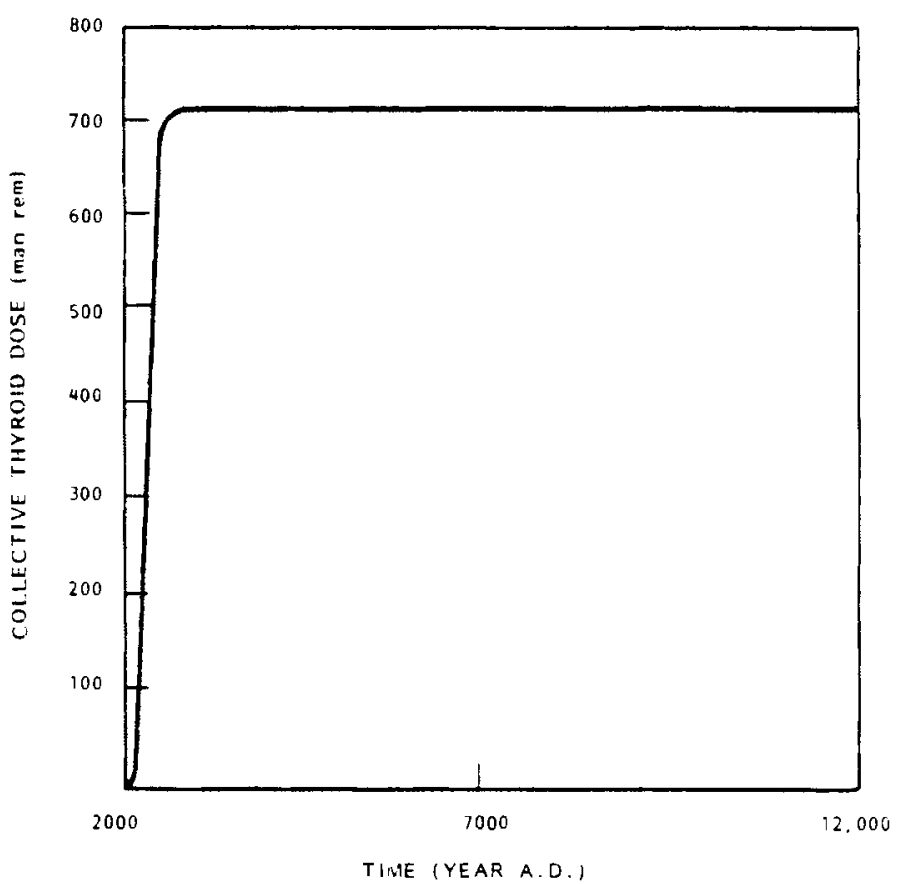

FIGURE B.7. Integrated Collective Thyroid Dose from Leakage from the $S$ and SX Farms,

Terminate Pumping Immediately Option

\section{B. 12}




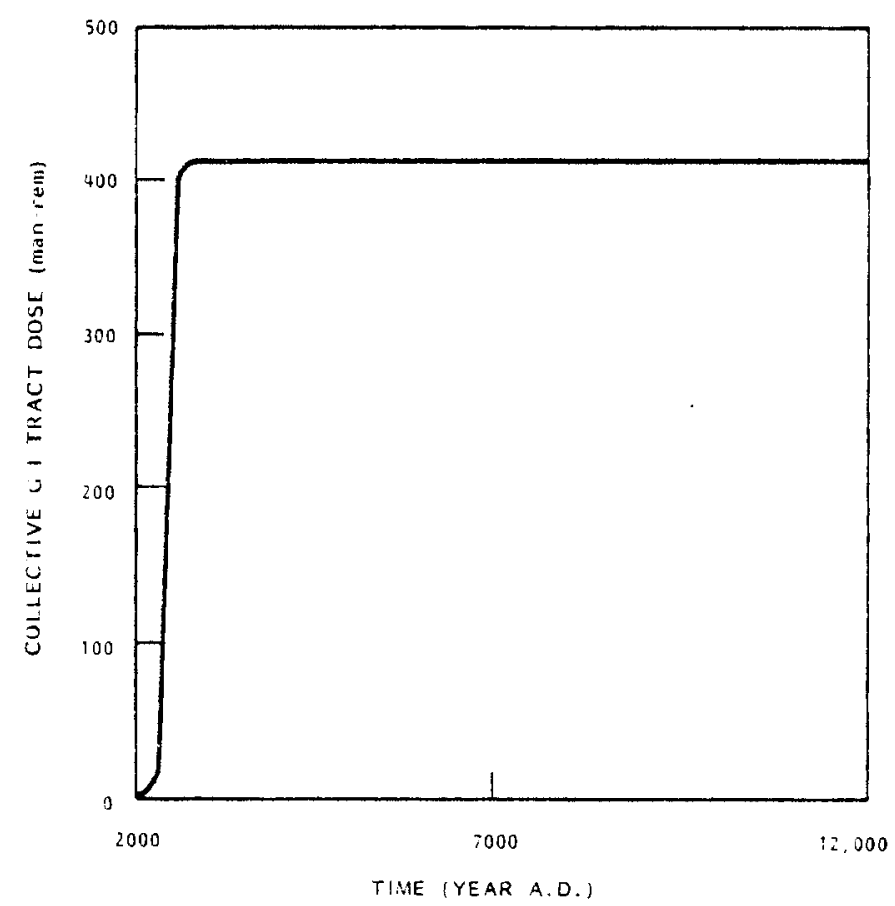

FIGURE B.8. Integrated Collective GI Tract Dose from Leakage from the $S$ and SX Farms, Terminate Pumping Immediately Option

neptunium-237 does not change the peak individuai dose. The greatest 1 ifetime dose to an individual, should pumping cease now and all the remaining IL leak, is about $3.6 \times 10^{-5}$ rem to total body, with a peak organ dose of about 6 millirem/lifetime. These doses are negligible with respect to the natural background dose of about $7 \mathrm{rem} / \mathrm{l}$ ifetime to an average individual. 
.

.

.

.

. 


\section{REFERENCES}

American Nuclear Society. 1976. Nuclear Power and the Environment. La Grange Park, Il Tinois.

Ames, L. L. and D. Rai. 1978. Radionuclide Interactions with Soil and Rock Media, Vol. I Processes Influencing Radionuclide Mobility and Retention, Element Chemistry and Geochemistry, Conclusions and Evaluations. PB-292-460, Office of Radiation Programs, U.S. Environmental Protection Agency, Washington, D.C.

Arnett, R. C., et al. 1977. Hanford Groundwater Transport Estimates for Hypothetical Radioactive Waste Incidents. ARH-LD-162, Atlantic Richfield Hanford Company, Richland, Washington.

Atlantic Richfield Hanford Company. 1973. 241-T-106 Tank Leak Investigation Report. ARH-2874, Richland, Washington.

Bear, J. 1972. Dynamics of Fluids in Porous Media. American Elsevier Publishing Company, New York.

Bowers, D. E., S. J. Joncus and R. D. Prosser. 1982. Jet Pumping Review. RHO-WM-EV-1, Rockwell Hanford Operations, Richland, Washington.

Brouns, R. A., and C. C. Timmerman. 1982. "In Situ Thermoelectric Stabilization of Radioactive Waste" in Proceedings of the Symoosium on Waste Management. Tucson, Arizona, March 8-11, 198 .

Brown, D. J. 1960. Geology Underlying 200 Area Tank Farms. HW-67729, General Electric Company, Richland, Washington.

Browne11, L. E., et a1. 1975. Soil Moisture Transport in Arid Site Vadose Zones. ARH-ST-123, Atlantic Richfield Hanford Company, Richland, Washington.

Catlin, R. J. 1980. Assessment of the Surveillance Program of the High-Level Waste Storage Tanks at Hanford. U.S. Department of Energy, Washington, D.C.

Coles, D. G. and L. D. Ramspott. 1982. "Migration of Ruthenium-106 in a Nevada Test Site Aquifer Discrepancy Between Field and Laboratory Resuits," in Science, Vol. 215, March 5, 1982.

Eddy, P. A. and J. S. Wilbur. 1981. Radiological Status of the Ground Water Beneath the Hanford Site, January-December 1980. PNL-3768, Pacific Northwest Laboratory, Richland, Washington.

Eddy, P. E., D. A. Myers and J. R. Raymond. 1978. Vertical Contamination in the Unconfined Ground Water at the Hanford Site, Washington. PNL-2724, Pacific Northwest Laboratory, Richland, Wasnington. 
Egger, J. V. 1981. Description of Potential Failure Modes for Single-Shell Waste Tanks. RHO-CD-1485, Rockwell Hanford Operations, Richland, Washington.

Enge1, R. L., J. Greenborg and M. M. Hendrickson. 1966. ISOSHLD--A Computer Code for General Purpose Isotope Shielding Analysis. BNWL-236, Pacific Northwest Laboratory, Richland, Washington.

Federal Register. 1982. Volume 47, p. 23801. "Defense Waste Processing Facility Savannah River Plant Aiken, South Carolina, Record of Decision."

Graham, M. J. 1981a. Hydrology of the Separations Area. RHO-ST-42, Rockwell Hanford Operations, Richland, Washington.

Graham, M. J. 1981b. A Radionuclide Ground-Water Monitoring Program for the Separation Area, Hanford Site, Washington State. RH0-SA-216, Rockwel1 Hanford Operations, Richland, Washington.

Houston, J. R., D. L. Strenge and E. C. Watson. 1974. DACRIN--A Computer Program for Calculating Organ Dose from Acute or Chronic Inhalation. BNWL-B-389, Pacific Northwest Laboratory, Richland, Washington.

Isaacson, R. E. 1981. Tables of Monitoring Frequencies for 200 East and West Area Single-Shell Waste Tank Ory Wells and Laterals. RHO-CD-1580, Rockwell Hanford Operations, Richiand, Washington.

Isaacson, R. E. and K. A. Gasper. 1981. A Scientific Basis for Establishing Dry Well Monitoring Frequencies. RHO-ST-34, Rockwell Hanford Operations, Richland, Washington.

Kipp, K. L., et a?. 1976. Variable Thickness Transient Ground-Water Model, Theory and Numerical Implementation. BNWL-1703, Pacific Northwest Laboratory, Richland, Washington.

Kurath, D. E. 1981. Criterion for Selection of 100 Series Tanks to be Jet Pumped. RHO-CD-1273, Rockwell Hanford Operations, Richland, Washington.

McCann, D. C. 1982. Waste Status Summary--May 1982. RHO-RE-SR-14, Rockwe 11 Hanford Operations, Richland, Washington.

McCormack, W. D. 1982. Hanford Dose Overview Program Report. PNL-3777, Pacific Northwest Laboratory, Richland, Washington.

Medvedev, Z. A. 1979. Nuclear Disaster in the Urals. W. W. Norton and Company, New York.

Mercer, B. W. 1967. Ion Exchange Equilibrium of Trace Cesium-137 and Strontium-85 in Multicomponent Systems. BNWL-SA-1173, Pacific Northwest Laboratory, Richland, Hashington. 
Napier, B. A. 1981. Standarized Input for Hanford Environmental Impact Statements. PNL-3509, PT 1, Pacific Northwest Laboratory, Richland, Washington.

Napier, B. A., W. E. Kennedy, Jr. and J. K. Soldat. 1980. PABLM--A Computer Program to Calculate Accumulated Radiation Dose from Radionuclides in the Environment. PNL-3209, Pacific Northwest Laboratory, Richland, Washington.

National Academy of Sciences. 1978. Radioactive Wastes at the Hanford Reservation, A Technical Review. National Research Council, Washington, D.C.

National Council on Radiation Protection. 1977. Radiation Exposure from Consumer Products and Miscellaneous Sources. Report No. 56, Washington, D.C.

National Council on Radiation Protection and Measurements. 1975. Review of the Current State of Radiation Protection Philosophy. Report No. 43, Washington, D.C.

Petrie, J. C., et al. 1976. "Vacuum Evaporator-Crystalizer Handles Radioactive Waste," Chemical Engineering Progress.

Price, W. H. and K. R. Fecht. 1976a. Geology of the 241-A Tank Farm. ARH-LD-127, Atlantic Richfield Hanford Company, Richland, Washington.

Price, W. H. and K. R. Fecht. 1975b. Geology of the 241-AX Tank Farm. ARH-LD-128, Atlantic Richfield Hanford Company, Richland, Washington.

Price, W. H. and K. R. Fecht. 1976c. Geology of the 241-8 Tank Farm. ARH-LD-129, Atlantic Richfield Hanford Company, Richland, Wasnington.

Price, W. H. and K. R. Fecht. 1976d. Geoiogy of the 241-BX Tank Farm. ARH-LD-130, Atlantic Richfield Hanford Company, Richland, Washington.

Price, W. H. and K. R. Fecht. 1976e. Geology of the 241-8Y Tank Farm. ARH-LD-131, Atlantic Richfield Hanford Company, Richland, Washington.

Price, W. H. and K. R. Fecht. 1976f. Geology of the 241-C Tank Farm. ARH-LD-132, Atlantic Richfield Hanford Company, Richland, Washington.

Price, W. H. and K. R. Fecht. 1976g. Geology of the 241-s Tank Farm. ARH-LD-133, Atlantic Richfield Hanford Company, Richland, Washington.

Price, W. H. and K. R. Fecht. 1976h. Geology of the 241-Sx Tank Farm. ARH-LD-134, Atlantic Richfield Hanford Company, Richland, Washington.

Price, W. H. and K. R. Fecht. 1976i. Geology of the 241-T Tank Farm. ARH-LD-135, Atlantic Richfield Hanford Company, Richland, Washington.

Price, W. H. and K. R. Fecht. 1976j. Geology of the 241-TX Tank Farm. ARH-LD-136, Atlantic Richfield Hanford Company, Richland, Washington. 
Price, W. H. and K. R. Fecht. 1976k. Geology of the 241-TY Tank Farm. ARH-LD-137, Atlantic Richfield Hanford Company, Richiand, Washington.

Price, W. H. and K. R. Fecht. 19761. Geology of the 241-U Tank Farm. ARH-LD-138, Atlantic Richfield Hanford Company, Richland, Washington.

Quinn, D. J., et al. 1980. An Assessment of the Risk Associated with Continued Storage of High-Level Waste in Single-Shell Tanks at Hanford. RHO-LD-55, Rockwell Hanford Operations, Richland, Washington.

Reisenauer, A. E. 1979. Variable Thickness Transient Ground-Water Model, Volumes 1, 2, and 3. PNL-3160-1-2-3, Pacific Northwest Laboratory, Richland, Washington.

Rockwell Hanford Operations. 1982. Support Documentation for the Hanford Defense Waste EIS. RHO-HS-ST-2, VoT. 2, Environmental Engineering Group, Richland, Washington.

Rockwell Hanford Operations. 1981. Radioactivity in Gaseous Waste Discharged from the Separations Facilities During 1980. RHO-CD-80-35-40, Richland, Washington.

Rockwell Hanford Operations. 1980. Technical Aspects of Long-Term Management for High-Level Defense Waste at the Hanford Site. RHO-LD-141, Richland, Washington.

Routson, R. C., et al. 1981. Fission Product Sorption Parameters for Hanford 200 Area Sediment Types. RHO-ST-35. Rockwel] Hanford Operations, Richland, Washington.

Routson, R. C., et al. 1979. High-Level Waste Leakage from the 241-T-106 Tank at Hanford. RHO-ST-14, Rockwell Hanford Operations, Richland, Washington.

Routson, R. C., et al. 1978. Measurement of Fission Product Sorption Parameters for Hanford 200 Area Sediment Types. RHO-LD-73, Rockwel] Hanford Operations, Richland, Washington.

Routson, R. C. 1973. A Review of Soil-Waste Relationships on the Hanford Reservation from 1944 to 1967. BNWL-1464, Pacific Northwest Laboratory, Richland, Washington.

Routson, R. C., G. S. Barney and R. M. Smith. 1981. "Hanford Site Sorption Studies for the Control of Radioactive Wastes" in Nuclear Technology.

Routson, R. C., G. S. Barney and R. M. Smith. 1980. Sorption Studies at Hanford for the Control of Radioactive Wastes. RHO-SA-155, Rockwell Hanford Operations, Richland, Washington. 
Sehme1, G. A. 1979. "Chapter 12, Deposition and Resuspension Processes," in Atmospheric Sciences and Power Production. Darryl Anderson, Editor.

Sommer, D. J., R. G. Rau and D. C. Robinson. 1981. Population Estimates for the Areas Within a 50-Mile Radius of Four Reference Points on the Hanford Site. PNL-4010, Pacific Northwest Laboratory, Richland, Washington.

Strenge, D. L. and R. A. Peloquin. 1980. HADOC--A Computer Code for Calculation of External and Inhalation Doses from Acute Radionuclide Releases.

PNL-3503, Pacific Northwest Laboratory, Richland, Washington.

Strenge, D. L. and E. C. Watson. 1973. KRONIC--A Computer Program for Calculating Annual Average External Doses from Chronic Atmospheric Releases of Radionuclides. BiWWL-B-264, Pacific Nortwest Laboratory, Richland, Washington.

Sula, M. J., et al. 1982. Environmental Surveillance at Hanford for CY-1981. PNL-4211, Pacific Northwest Laboratory, Richland, Washington.

Sutter, S. L. 1980. Potential Airborne Release from Soil-Working Operations in a Contaminated Area. PNL-3498, Pacific Northwest Laboratory, Richland, Washington.

Tallman, A. M., et al. 1980. Geology of the Separations Area. RHO-ST-23, Rockivell Hanford Operations, Richland, Washington.

U.S. Code of Federal Regulations. Title 10, Part 50, Appendix I.

U.S. Department of Energy. 1981. Environmental Protection, Safety and Health Protection Programs for DOE Operations, Order 5480.1, Chapter XI. Washington, D.C.

U.S. Department of Energy. 1980a. Final Environmental Impact Statement, Hanford Site, Double-Shell Tanks for Defense High-Level Radioactive Waste Storage. DOE/EIS-0063, washington, D.C.

U.S. Department of Energy. 1980b. Final Environmental Impact Statement, Management of Commerciaily Generated Radioactive Waste. DOE/EIS-0045, Washington, D.C.

U.S. Energy Research and Development Administration. 1975. Final Environmental Statement Waste Management Operations, Hanford Site, Richland, Washington. ERDA-1538, 2 vols., Washington, D.C.

Van Genuchten, N. T. 1981. Non Equilibrium Transport Parameters from Miscible Displacement Experiments. Research Report 119, USDA Salinity Laboratory, Riverside, California.

Wallace, R. W., et al. 1980. Topical Report on Release Scenario Analysis of Long-Term Management of High-Level Defense Waste at the Hianford Site.

PNL-3363, Pacific Northwest Laboratory, Richland, Washington. 
Washburn, J. F., et a 1. 1978. Multicomporient Mass Transport Model: A Model. Pacific Northwest Laboratory, Richland, Washington.

Wilbur, J. S. and M. J. Graham. 1982. The Results of the Separations Area Ground-Water Monitoring Network for 1981. RHO-HS-SR-5P, Rockwell Hanford Operations, Richland, Washington.

Womack, J. C. and D. J. Larkin. 1971. Investigation and Evaluation of the 102-BX Tank Leak. ARH-2035, Atlantic Richfield Hanford Company, Richland, Washington.

Yandon, K. E., J. S. Burlison and R. G. Rau. 1980. Supplemental Report on Population Estimates for Hanford Defense Waste Draft Environmental Impact Statement. PNL-3507, Pacific Northwest Laboratory, Richland, Washington. 


\section{DISTRIBUTION}

No. of

Copies

OFFSITE

27 DOE Technical Information Center

2 Division of Waste Management Nuclear Regulatory Commission Wasnington, DC 20555

ATTN: J. B. Martin

R. F. Cook

Environmental Protection Agency

Technological Assessment

Division (AW-559)

Office of Radiation Programs

U.S. Environmental Protection Agency

Washington, DC 20460

2 DOE Terminal Waste Disposal and Remedial Action

NE-30, GTN

Washington, DC 20545

ATTN: F. E. Coffman

J. R. Coleman

J. W. Bennett

Geologic Repository Division

DOE Nuclear Waste Policy Act

Project Office

S-10, Forresta?

Washington, DC 20585

3 Geologic Repository Division

DOE Nuclear Waste Policy Act Project Oifice

GTN

Washington, DC 20545

ATTN: C. R. Cooley, S-10/NE-22

C. H. George, S-10/NE-22

R. Stein
No. of

Copies

M. J. Lawrence

Storage Projects

DOE Nuclear Waste Policy Act

Project Office

S-10, Forrestal

Washington, DC 20585

K. 0. Laughon

DOE Office of Spent Fuel Management and Reprocessing Systems

NE-40, GTN

Washington, DC 20545

5. DOE Office of Defense Waste and

Byproducts Management

DP-12, GTN

Washington, DC 20545

ATTN: J. E. Dieckhoner

G. K. Oertel

R. Scott

V. Trice

S. A. Mann

DOE Chicago Operations Office

9800 South Cass Avenue

Argonne, IL 60439

D. L. Vieth

DOE Nevada Cperations Office

Las Vegas, NV 89117

2 DOE Operations Office

P.O. Box E

Oak Ridge, TN 37830

ATTN: S. Ahrends

D. E. Large

L. Lanni

DOE San Francisco Operations Office

1333 Broadway, Wells Fargo Bldg

Dakland, CA 94612 
No. of

Copies

W. Hannum

DOE West Valley Demonstration

Project Office

West Valley, NY 14171

J. 0. Neff

DOE National Waste Program Office

505 King Avenue

Columbus, $\mathrm{OH} 43201$

J. B. Whitsett

DOE Idaho Operations office

550 2nd Street

Idaho Falls, ID 83401

2 DOE Savannah River Operations Office

P.0. Box A

Aiken, SC 29801

ATTN: T. B. Hindman

M. J. Sires, III

3 DOE Albuquerque Operations Office

P.O. Box 5400

Albuquerque, NM 87185

ATTN: K. Carlson

R. Y. Lowrey

D. T. Schueler

2 Oak Ridge National Laboratory

P.O. BoX Y

Oak Ridge, TN 37830

ATTN: J. 0. Blomeke

K. Notz

K. R. Braziel

Los Alamos Scientific Laboratory

P.0. Box 1663

Los Alamos, NM 87544

M. J. Steindler

Argonne National Laboratory

9700 South Cass Avenue

Argonne, IL 60439
No. of

Copies

2 Lawrence Livermore Laboratory

P.0. Box 808

Livermore, CA 94550

ATTN: J. H. Campbell

W. G. Sutcliff

3 Sandia Laboratories

Albuquerque, NM 87185

ATTN: D. R. Anderson

R. M. Jefferson

W. Weart

5 Battelle Memorial Institute Office of Nuclear Waste Isolation 505 King Avenue

Columbus, $\mathrm{OH} 43201$

ATTN: W. Carbiener

N. E. Carter

S. Goldsmith

P. L. Hofmann

B. Rawles

3 E. I. du Pont de Nemours Company

Savannah River Laboratory

Aiken, SC 29801

ATTN: J. L. Crandall

E. J. Hennelly

R. Maher

3 Allied-General Nuclear Services

P.0. Box 847

Barnwell, SC 29812

ATTN: J. A. Buckham

W. L. Godfrey

A. Williams

J. L. Knabenschuh

West Valley Nuclear Services

West Valley, NY 14171

R. Williams

Electric Power Research

Institute

3412 Hillview Avenue

P.0. Box 10412

Palo Alto, CA 94304 
No. of

Copies

ONSITE

4 DOE Richland Operations Office

0. J. Elgert

R. D. Izatt.

H. E. Ransoin

J. J. Schreiber

6 Rockwe!1 Hanford Operations

L. R. Fitch

K. A. Gasper

B. E. Knight

H. E. McGuire

J. W. Patterson

S. A. Wiegman

UNC United Nuclear Industries

T. E. Dabrowski

Westinghouse Hanford Company

A. G. Blasewitz
No. of

Copies

32 Pacific Northwest Laboratory

W. F. Bonner

J. B. Brown

T. D. Chikalia

E. A. Eschbach

R. M. Fleischman

W. A. Glass

C. R. Hann

J. H. Jarrett

D. E. Knowlton

J. M. Latkovich

R. C. Liikala/J. L. MicElroy

K. S. Murthy (3)

B. A. Napier

I. C. Neison

R. E. Nightingaie

A. M. Platt

J. V. Robinson (2)

S. L. Stein

L. A. Stout

E. M. Toomey

H. H. VanTuyi

L. D. Williams

Technical Information (5)

Publishing Coordination (2) 